\title{
THE FAUNA OF SAND AND MUD BANKS NEAR THE MOUTH OF THE EXE ESTUARY
}

\author{
By N. A. Holme, B.A.
}

From the Plymouth Laboratory

(Plates I and II and Text-figs. I-II)

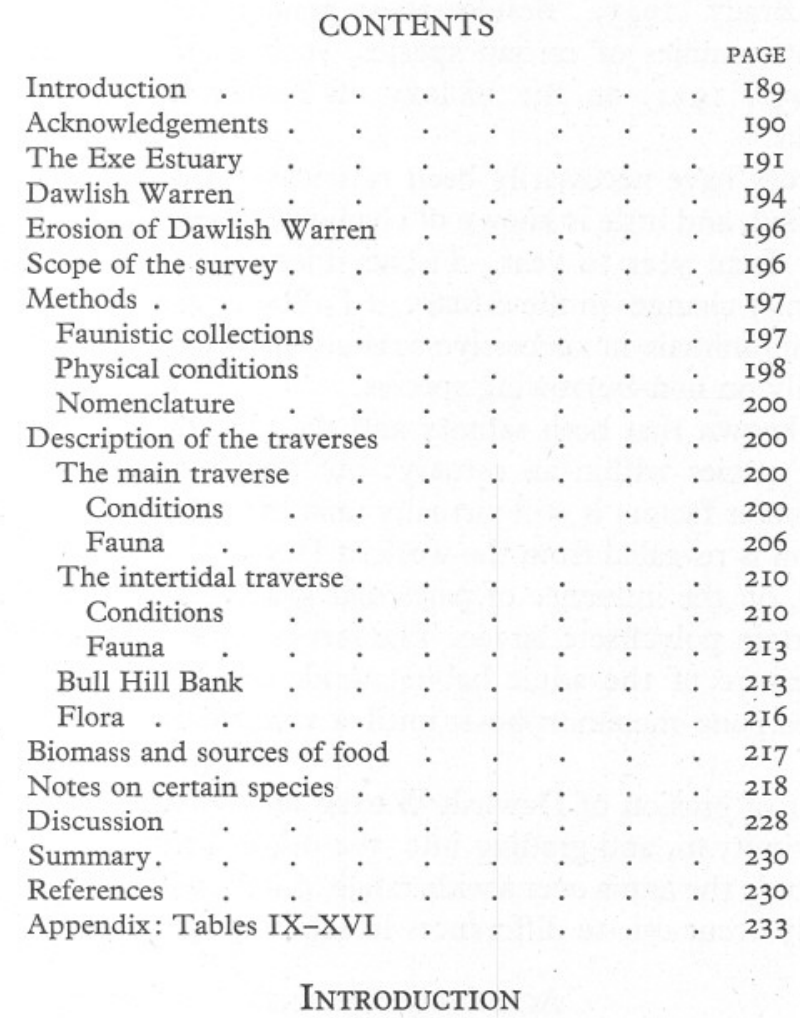

In I90I Allen \& Todd (1902) made a survey of the fauna of the Exe Estuary consisting of collections of the macrofauna of the intertidal sand and mudbanks, and some trawling and dredging. An account of the Foraminifera of the estuary is given by Worth (I902). Since I90I, considerable changes have occurred in the physiography of the lower part of the estuary, and the present paper records some observations made on the fauna in the area most affected by these changes.

The papers by Allen \& Todd (1900, 1902) on the Salcombe and Exe Estuaries are almost the first comprehensive estuarine surveys. Since about 
I928 a number of more detailed surveys have been published, some of which deal with the quantitative aspects of populations in sand- and mud-banks. One of the most recent of these is that by Spooner \& Moore (1940) on the macrofauna of the intertidal muds of the Tamar estuary. Serventy's (1934) survey of the Scolt Head Island fauna and Beanland's (1940) work on the Dovey estuary are accounts of the fauna of sand-and mud-banks in sheltered and near-marine conditions, comparable to those described in this paper.

Populations on sandy and muddy shores have been described by Stephen (I929 a), Elmhirst (I93I), Pirrie, Bruce \& Moore (1932), Rees (1939), Watkin (I942), and Brady (I943). Besides these general surveys, there have been more intensive studies of certain species, such as those of Stephen (I928, I929a, $b$, I93I, I932) on the biology of Tellina tenuis and certain other lamellibranchs.

Most surveys have necessarily been restricted to collections made during a limited period, and little is known of changes in the populations from season to season or from year to year. Fischer-Piette (I93I) found a correlation between salinity changes in the estuary of La Rance and the up-river penetration of certain animals in successive seasons and years, but his observations were primarily on non-burrowing species.

It is well known that both salinity and the type of soil influence the distribution of species within an estuary; but the exact role of each and the influence of other factors is still virtually unknown. Some light on the causes of distribution is revealed from the work of Day \& Wilson (1934) and Wilson (1937, I948), on the influence of particular grades of sand on the metamorphosis of certain polychaete larvae. The larvae show a tendency to settle on soil characteristic of the adult habitat, and, as Ophelia bicornis from the Exe, may postpone metamorphosis until a suitable grade of sand has been reached.

As a result of erosion of Dawlish Warren an area of sand has come to lie in close proximity to, and grading into, the original mud-banks. Thus it was possible to study the fauna over a wide range of soils, without the complications which usually occur due to differences in salinity, currents or wave action.

\section{ACKNOWLEDGEMENTS}

I am indebted to the Trustees of the Balfour Fund for a grant to meet collecting expenses, and to the Deputy Provincial Director of the Ministry of Agriculture and Fisheries at Starcross for the provision of accommodation while collecting was in progress. I am also grateful to the Soils Department of the above establishment for their help with the $\mathrm{pH}$ readings, and in other ways. Much of the collecting equipment was kindly lent by the Director of the Plymouth Laboratory.

I am especially indebted to Dr C. F. A. Pantin, F.R.S., for his help, both as Administrator of the Balfour Fund, and for his encouragement and advice 
in planning the course of the work. The collecting and the sorting of specimens at Starcross was only made possible by the generous help of the following: Miss U. M. Grigg, Miss S. M. Davies, and Messrs B. O. C. Gardiner, D. Langridge, R. M. Laws, A. J. Lee, A. W. Mansfield and H. Swift. Mr and Mrs G. M. Spooner were also of great assistance for a few days at the beginning of the summer. Mr A. J. Lee, who was surveying the Warren, has kindly provided an up-to-date map of the area which is reproduced, with modifications, in this paper.

The following have been of great assistance in the techniques of measuring physical conditions: Dr H. W. Harvey, F.R.S., Dr C. H. Mortimer and Dr J. A. Ramsay.

The later stages of this work and the writing of this paper were made during the term of a D.S.I.R. training grant at the Plymouth Laboratory. I am indebted to the Director and Staff of the Plymouth Laboratory for advice and assistance during this period.

Certain salinity readings were kindly supplied by the Ministry of Agriculture and Fisheries, Fisheries Experimental Station, Castle Bank, Conway.

The following have been kind enough to identify or check certain groups: Nemertinea-Dr J. E. Smith; Annelida-Mr D. P. Wilson; MolluscaDr V. Fretter, Miss S. M. Davies, Miss U. M. Grigg, Mr R. Winckworth; Crustacea-Dr E. E. Watkin, Mr G. M. Spooner, Mrs W. M. Tattersall; Pisces (Ammodytes)-Mr P. G. Corbin; Zostera spp.-Mr T. G. Tutin; Algae-Dr M. Parke.

I am indebted to Mr F. S. Russell, F.R.S. and Dr T. J. Hart for helpful criticism of the manuscript.

\section{The EXE Estuary}

The River Exe is tidal up to Countess Wear, 9 miles from the mouth, but between Countess Wear and Topsham the channel is fairly narrow and the water is almost fresh. Between Topsham and Exmouth the estuary is about a mile wide and is 6 miles long. A small river, the Clyst, enters the estuary near Topsham and a few streams flow into the estuary at various points. At high tide the estuary is almost completely covered by water, but at low tide extensive sand- and mud-banks are uncovered through which a shallow main channel winds. Near Exmouth the estuary narrows, being diverted at right angles to the east by a sand spit on the western shore, called Dawlish Warren. The channel runs parallel to Exmouth shore for 2 miles, being separated from the sea at low tide by a large sand-bank known as Pole Sands. The banks in the upper part of the estuary are of mud, but nearer Exmouth they become more sandy. Two banks of clean sand occur near the mouth: Bull Hill Bank and Pole Sands. The river channel is well scoured and has a bed of stones in the lower part of the estuary. 
Tidal streams are very swift, particularly near the mouth. Opposite Exmouth Dock a speed of 5 knots $(9 \cdot 25 \mathrm{~km}$. $/ \mathrm{hr}$.) may be reached on spring tides. The scour produced by the currents causes banks opposite the main channel to slope down steeply near low-water mark. Thus most of the banks are at high- and mid-tide levels, and very little additional area is uncovered at low spring as compared with low neap tides. The tidal range is $12 \cdot 2 \mathrm{ft}$. $(3.72 \mathrm{~m}$.) at spring tides, and $4.8 \mathrm{ft}$. $(\mathrm{I} \cdot 46 \mathrm{~m}$.) at neap tides.

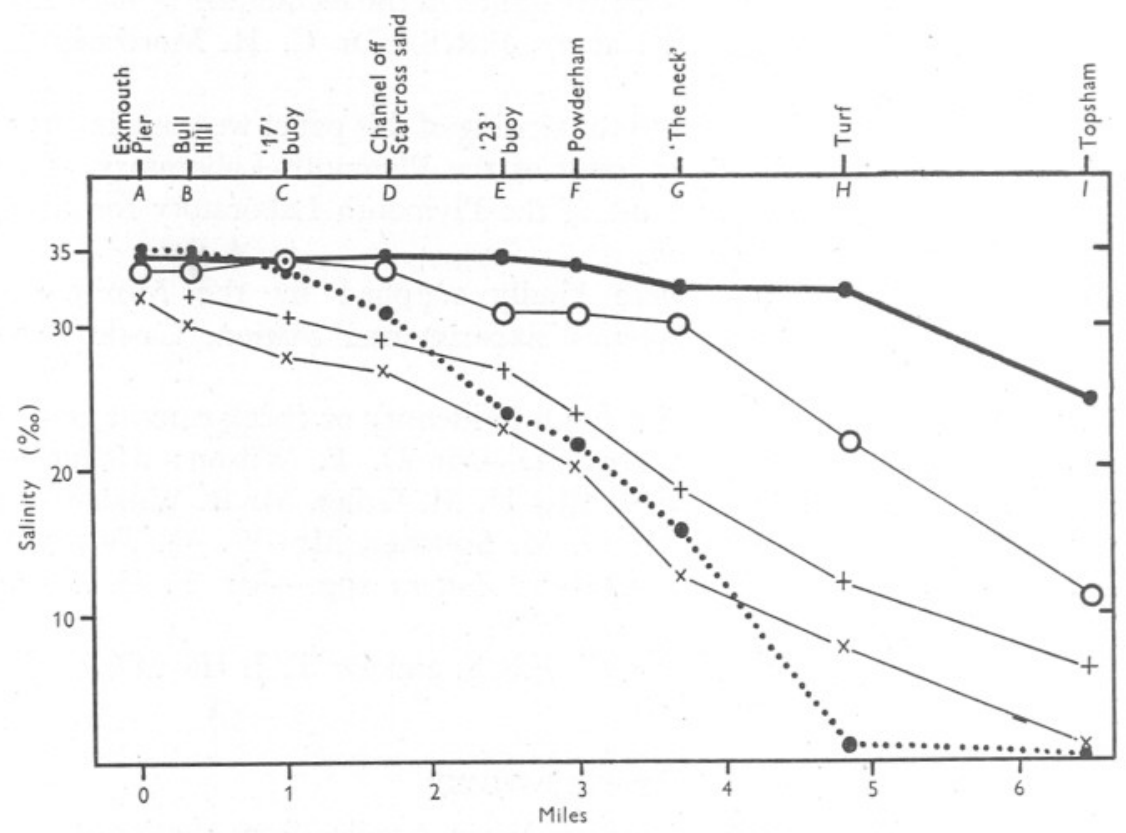

Fig. I. Surface salinities in the Exe Estuary. Distances are measured up the main channel from Exmouth Pier. The area studied in this paper is opposite the station marked 'Bull Hill'. Samples were taken on the following occasions:- - - high spring tide (I2 ft. 5 in.), 3. ix. 47; - - - high neap tide ( 9 ft. 6 in.), 27. vii. $47 ;-+-$, low neap tide (10 ft. 2 in.), 28 . viii. $47 ;-\times-$, low spring tide (I2 ft. 2 in.), 18. vii. $47 ; \cdots \bullet \cdots$, high neap tide (Io ft. 2 in.), 2. iii. 48.

A certain amount of sand is mixed with all the deposits; and in dry windy weather sand may be blown up the estuary from Dawlish Warren, so adding to the sand-content of the banks.

The considerable width of the estuary enables small waves to be formed within it, and in addition swell from the sea may be felt as far up as Starcross at high tide. During a recent south-east gale the sea was sufficiently rough inside the estuary to damage severely the railway embankment below Starcross. 
Sewage from Exeter is discharged into the river near Countess Wear, and sewers empty into the estuary opposite the villages and towns on its shores. There is no chemical pollution.

The extent of the fresh-water inflow was discussed by Allen \& Todd (1902). The watershed area of the Exe is 584 square miles $\left(1512 \mathrm{~km}^{2}{ }^{2}\right)$ and it was found that conditions at Exmouth were almost marine, whereas at Topsham fresh water was recorded at low tide after heavy rain. Some additional salinity records are given in this paper. They were made by running a motor-boat at top speed up the estuary, taking surface water samples at intervals. Starting about half an hour before high or low tide it was possible to take most of the samples during the period of slack water. Samples were taken at high and low spring and neap tides in the summer of 1947, and one set of samples was taken in March I948. The results are summarized in Table IX and Fig. I. In the lower part of the estuary conditions are marine at high tide, but salinity drops to about $30 \%$ at low tide. The greatest range of salinity occurs at about Turf, $\mathrm{I} \frac{1}{2}$ miles below Topsham, and the river is evidently brackish for a short distance above Topsham.

It seems likely, however, that few estuarine species are subjected to such extremes of salinity. At low tide the greater part of each bank is uncovered, and so not exposed to the lowest salinities. In addition, Reid (I930) has shown that a stream of fresh water flowing over intertidal sand has little effect on the salinity of the water retained in the sand, which presumably is of about the mean of the various salinities to which the bank is subjected. Species with an 'open' burrow, such as Arenicola will, however, be exposed to the salinity of the overlying water rather than to that of the surrounding sand.

The fauna of buoys is exposed to the surrounding water at all times, but Milne (1940) has shown that mussels close their valves when the salinity drops below $25 \%$, the water retained in the shell at low tide being of higher salinity than that of the water outside.

The main channel is shallow for the greater part of its length. This, and the ease with which the water may be disturbed by waves and currents, renders it unlikely that any marked stratification of water layers of different salinities would occur. Some records made in connexion with the Ministry of Agriculture and Fisheries' Mussel-Washing Station at Lympstone show, however, that stratification may occur under certain conditions:

\section{(a) In calm weather (25 September 1917)}

Neap tides. High water $\mathrm{I} 2$ noon. Wind S., light. Samples in channel off Powderham Boathouse (half-way up the estuary).

$\begin{array}{lll}\text { 5.I2 p.m. } & \text { Density at surface } & \mathrm{I} \cdot 009 \\ \text { 5.I5 p.m. } & \text { Density at bottom }(9 \mathrm{ft} .) & \mathrm{I} \cdot 023 \\ \text { 5.20 p.m. } & \text { Density at bottom }(9 \mathrm{ft} .) & \mathrm{I} .02 \mathrm{I} \\ \text { 5.25 p.m. } & \text { Density at surface } & \mathrm{I} .005\end{array}$




\section{(b) During floods (I8 January I9I8)}

High tide IO.I9 a.m. Water very high, due to floods and melting snow. Winds S.W., fresh. In channel between Starcross and Lympstone.

$\begin{array}{lll}\text { I2.I5 p.m. } & \text { Density at surface } & \mathrm{I} \cdot 002 \\ \text { I2.I5 p.m. } & \text { Density at } 6 \mathrm{ft} \text { depth } & \mathrm{I} \cdot 0 \mathrm{I} 5 \\ \text { I2.20 p.m. } & \text { Density at } 8 \mathrm{ft} \text { depth } & \mathrm{I} \cdot 02 \mathrm{I} \\ \text { I2.20 p.m. } & \text { Density at } 5 \mathrm{ft} \text { depth } & \mathrm{I} \cdot 004 \\ \text { I2.23 p.m. } & \text { Density at } 6 \mathrm{ft} \text { depth } & \mathrm{I} \cdot 0 \mathrm{I} 7 \\ \text { I2.25 p.m. Density at } 7 \mathrm{ft} \text { depth } & \mathrm{I} \cdot 020 \\ \text { I2.27 p.m. } & \text { Density at surface } & \mathrm{I} \cdot 002\end{array}$

Clearly fresh water was flowing out over the denser salt water, the line dividing the two water masses being at a depth of 5-6 ft. The surface samples were muddy, while the bottom water samples were clear.

\section{DAWLISH WARREN}

The Warren is a spit jutting out across the mouth of the Exe, and formerly narrowing it to a channel a quarter of a mile wide between Warren Point and Exmouth (see Fig. 2). It consists of two separate spits: the Outer and Inner Warren. The Outer Warren is a line of sand-dunes on the seaward side of the Inner Warren; it was (in 1939) about $\mathrm{I} \frac{1}{2}$ miles long, its north-eastern end forming an area known as Warren Point, on which were a number of bungalows. The Outer Warren has been subject to considerable erosion in recent years, and Warren Point has now disappeared.

Between the Inner and Outer Warren is a low area with little vegetation known as Greenland Lake. This was formerly flooded at high spring tides, but its connexion with the sea has now been closed by a barricade. It is, however, still liable to occasional flooding, and this presumably prevents the establishment of permanent vegetation.

The Inner Warren is an established spit, with a heath-like appearance, and a few small trees. The soil is sandy, and it is used as a golf course. This spit was rather shorter than the Outer Warren and has until recently been completely protected by the latter on its seaward side.

A survey of the Warren made by $\mathrm{Mr} \mathrm{A}$. J. Lee showed that the Inner Warren is founded upon a bed of clay rising above high-water mark. On the seaward side the clay dips down steeply and has not been found under the Outer Warren. On the northern shore of the Warren the clay is visible on the surface in places, and forms a gently sloping layer under the mud flats for some distance from it.

These observations confirm the suggestion made by Worth (I902) that the western end of the Warren is a genuine spit of land, whereas the eastern end and the Pole Sands are due to littoral drift. 


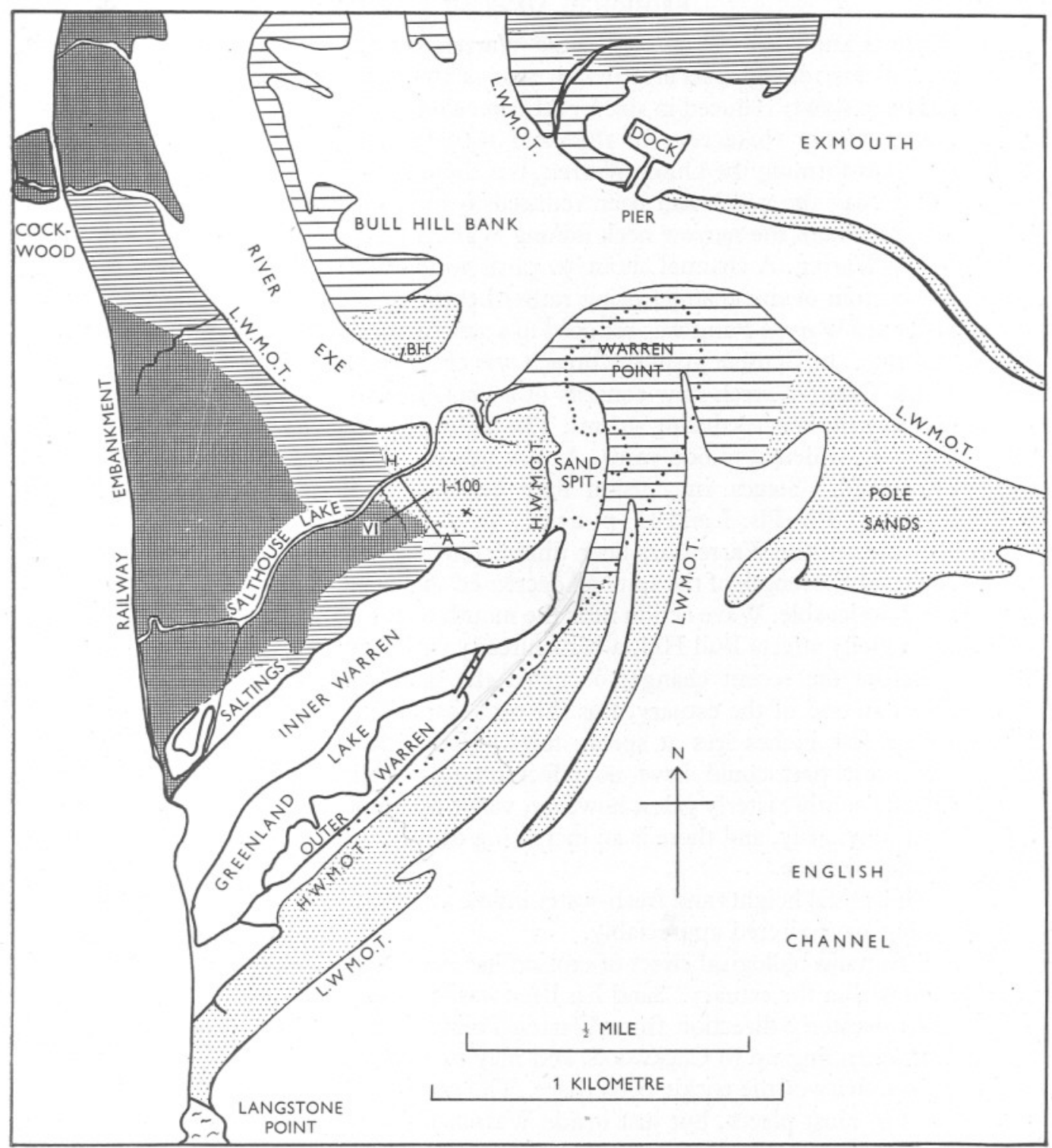

Fig. 2. Map of the lower part of the Exe Estuary, from a survey by A. J. Lee, July I947. The position of the traverses is indicated. Note that erosion has nearly doubled the high-tide channel opposite Exmouth.

Mud. ए ए ..... Outline of Warren Point in 1935 


\section{EROSION OF DAWLISH WARREN}

Little is known of the extent of the Warren before the eighteenth century; records for 1723 give its area in that year as 398 acres. Since then the Warren has been slowly reduced in size by attrition along its seaward face. In I 888 the area was only I9I acres. In I859 and I869 breaches were made in the line of dunes forming the Outer Warren, but these were subsequently closed. By about 1943 the width had been reduced to such an extent that a breach was made through the narrow neck joining Warren Point to the remainder of the Outer Warren. A channel about 50 yards wide was formed through the spit, the bottom of the channel being rather below half-tide mark. Between I943 and 1946 Warren Point was reduced to a sand bank by the action of waves and currents. In October 1946 the breach was closed by littoral drift, and the end of the Outer Warren now consists of a hooked sand spit over which the sea occasionally washes during storms. The high-water channel opposite Exmouth has been widened to 600 yards. At low tide the remains of Warren Point are uncovered. Stages in erosion may be seen in the aerial photographs reproduced in Pls. I and II (p. 232).

Although the Warren has been diminishing in width for a long time, it was not until the length of the spit had decreased that any effects within the estuary were noticeable. Wave action near the mouth of the estuary has increased, but this chiefly affects Bull Hill, a bank already well scoured by currents.

Before the recent changes occurred the tidal range at Topsham, at the northern end of the estuary, was the same as at Exmouth at neap tides, and only a few inches less at spring tides. Hence the increase in width at its narrowest part could have no effect on tidal heights within the estuary. During south-easterly gales, however, water accumulates in the estuary more than previously, and there is an increasing danger to the railway embankment in consequence.

Since tidal heights and fresh-water inflow are unchanged, salinity conditions cannot have altered appreciably.

The main biological effect of erosion has been through the redistribution of sand within the estuary. Sand has been washed and blown up the estuary in a north-westerly direction from Warren Point. The sand has come to lie in a belt extending up to Cockwood, and may be responsible for a decline in the productivity of the cockle beds there. The sand has become mingled with the mud in most places, but just inside Warren Point there is a stretch of newly deposited clean sand. Two hundred yards to the west is an area of mud covered with Zostera. In the intermediate zone a range of soil types, from sand to mud, is found.

\section{SCOPE OF THE SURVEY}

Since 1902 there has been little published work on the estuary. Crawford (I937c) recorded certain Crustacea from the estuary; and Beanland (I940) 
considered that the absence of Corophium volutator from an area in which it had been found by Allen \& Todd was due to decreasing shelter resulting from erosion of the Warren.

The area selected for study lies between Dawlish Warren and a small stream running parallel to it through the mud flats, known as Salthouse Lake. Allen \& Todd (I902) did not collect here, but they gave a list of species from a similar ground at a slightly lower level to the north of the stream.

In all, collections were made on three traverses: (i) along a traverse passing from sand to mud, stations all being at about half-tide level; (ii) on an intertidal traverse in the same region, passing from high- to low-water marks, in which most stations were on sand; (iii) a short traverse across the top and edge of Bull Hill Bank.

\section{Methods}

\section{Faunistic collections}

Collections were made of a $\frac{1}{4} \mathrm{~m} .^{2}$ surface area dug to a depth of about Io in. The area to be dug was marked out by a square metal frame of side half a metre and depth 6 in., which was driven into the ground. This prevented collapse of soil into the hole during digging.

The soil was sieved through a gauze sieve with holes I mm. square. A 'souping' technique, as used by Spooner \& Moore (I940), was adopted in the muddier areas. Practically all the soil passed through the sieve at most stations, but Zostera and other plant remains were often abundant in the sievings. Now and then a sieve with round holes $0.8 \mathrm{~mm}$. across was also used, but never on the top $2-3$ in. of soil where small individuals chiefly congregate. Occasionally, mainly in the Zostera areas, sub-sampling was resorted to after the larger specimens had been picked out.

'Sievings' were taken back to Starcross, where they were sorted and preserved, with preliminary identifications. All specimens were kept and have been identified and size-grouped by the author while at Plymouth.

The collecting technique seems adequate for all the larger specimens, but it is likely that only a fraction of the smaller worms, etc., were retained by the sieve. With animals of a definite shape and size, such as the Gastropod Hydrobia ulvae, a constant lowest size of animal is retained by the sieve; but the proportion of other small specimens must largely depend on the duration and violence of sieving: in time all would pass through. At least one moderatesized worm (Scoloplos armiger?) has a habit of actively crawling through the meshes of the sieve and so tends to be lost.

In so far as no animals below I mm. were included, this survey of the populations is incomplete. But the study of the micro- and meio-benthos requires special techniques outside the scope of this work. A sieve with mesh of I mm. is about the smallest that can conveniently be used for sieving a large bulk of sand, and for subsequent sorting without resorting to a lens. 
Along each traverse stations were at $100 \mathrm{ft}$. $\left(30^{\circ} 48 \mathrm{~m}\right.$.) intervals; at each two collections were made $3 \mathrm{ft}$. on either side of the station along the line of the traverse. These were designated as +3 and $-3 \mathrm{ft}$. from each station.

Intermediate stations were also worked and are designated by the distance in feet from the preceding station. Thus Station II +33 was $33 \mathrm{ft}$. from Station II and $67 \mathrm{ft}$. from Station III. Stations were I-100, I, II, III, IV, V and VI on the main traverse, and A, B, C, D, E, F, G and $\mathrm{H}$ on the intertidal traverse. These traverses cross at Stations II and E, which are therefore identical. Stations on Bull Hill were measured in feet from a point ' $\mathrm{BH}$ ' at the top of the steep slope of the bank.

Population figures from adjacent collections at each main station are given separately to emphasize the variation to be expected due to patchy distribution of certain species.

\section{Physical conditions}

Salinity was measured in two ways:

(i) Titration with silver nitrate solution using potassium dichromate as indicator. Comparison was made by titration of a sea-water sample taken at sea outside the estuary. This was assumed to have a salinity of $35.0 \%$ as no accurate salinity determinations were made.

(ii) Using a brass and also a glass hydrometer with density ranges from fresh to salt water. These instruments give an approximate reading only, to which a temperature correction must be applied.

$p H$. The $\mathrm{pH}$ of marine soils seems to be chiefly related to the carbon dioxide concentration ( $\mathrm{Dr} \mathrm{H}$. W. Harvey: personal communication), and since determinations were not made in the field it is difficult to assess the importance of this factor. The $\mathrm{pH}$ of the water in the soil was determined by comparing samples, obtained by digging a small hole in the soil and allowing it to fill with water, with standard buffer tubes, using cresol red as indicator.

$\mathrm{pH}$ was also measured electrically. A glass jar was filled full of soil, and from the middle of this sample a small quantity was taken out for $\mathrm{pH}$ measurement, which was determined within $24 \mathrm{hr}$. of collection. The soil was mixed to a smooth paste with the minimum quantity of sea water, and the $\mathrm{pH}$ of the mixture measured.

Temperature. Readings of soil temperatures were made by inserting a thermometer into a small hole in the ground made with a stick. Temperatures were recorded with the bulb at $\frac{1}{2}$ in. and at 3 in. depths below the surface.

Water table. A small hole dug in the soil was allowed to fill with water. The top of the water is approximately equal to the level of the water table.

Tidal levels. A number of stations were levelled to Ordnance Datum by means of a 'Dumpy Level' and a bench-mark on Dawlish Warren. Tidal heights are given relative to Chart Datum, which is $0.2 \mathrm{ft}$. below M.L.W.M.S.T.

Soil analysis. Grade analysis was carried out by means of the standard method used in agriculture. This method has been applied with success to 
soils on the shore by Beanland (1940) and Watkin (1942). It is not in itself sufficiently precise to distinguish the slight differences in soil grade which seem to affect the distribution of certain species. If material retained on the standard $0.2 \mathrm{~mm}$. sieve is passed through a series of sieves of slightly coarser mesh a more exact grading of the sand can be achieved.

Owing to difficulty in obtaining a Standard 70 I.M.M. (0.2 mm.) sieve, a sieve of 80 meshes to the inch was substituted. This had openings $0.22 \mathrm{~mm}$. across. Results obtained with this sieve have been compared with those made with a standard sieve (Table X). Many of the grains were about $0.2 \mathrm{~mm}$. in size so that there is some divergence in results from those made with the standard sieve. In the present investigation the following grades were distinguished:

Stones and fine gravel Retained on $2 \mathrm{~mm}$. sieve

Very coarse sand

Coarse sand

Medium sand

Fine sand

Silt and clay
Retained on $0.5 \mathrm{~mm}$. sieve

Retained on $0.256 \mathrm{~mm}$. sieve

Retained on $0.22 \mathrm{~mm}$. sieve

$0.22-0.02 \mathrm{~mm}$.; passing $0.22 \mathrm{~mm}$. sieve and settling in $5 \mathrm{~min}$. Less than $0.02 \mathrm{~mm}$; still in suspension after $5 \mathrm{~min}$.

The method used is based on that described by Piper (1942):

Samples were taken from the top 4 in. of soil and were air-dried.

The soil was graded through a $2 \mathrm{~mm}$. sieve, all retained on the sieve being rejected. Io g. of soil were weighed out and were treated with hydrogen peroxide in the cold, and subsequently at $100^{\circ} \mathrm{C}$.

Hydrochloric acid was added to dissolve carbonates.

Water was added until the depth in the beaker was $10 \mathrm{~cm}$.; this was allowed to stand and the liquid decanted off. This was repeated.

The small quantity of silt decanted off was allowed to settle, and was dried and weighed.

The soil was dispersed by rubbing with a rubber pestle, and was washed through a $0.22 \mathrm{~mm}$. sieve.

The sand retained on the sieve was dried and rubbed on the sieve until no more passed. Sand passing through was added to that in the beaker.

The residue on the sieve was graded through 0.5 and $0.256 \mathrm{~mm}$. sieves.

The material in the beaker was filled up to $10 \mathrm{~cm}$. depth with water and caustic soda solution was added. After stirring it was allowed to settle for $5 \mathrm{~min}$. (at $18^{\circ} \mathrm{C}$.). The silt was decanted off.

Successive decantations were made, a small quantity of concentrated ammonia solution being added each time. This was repeated until the liquid was clear after $5 \mathrm{~min}$.

The silt was allowed to settle in a large jar, and was dried and weighed. To this weight was added that obtained from decantation from acid solution.

The residue after decantation was fine sand.

Soil grades have been expressed as percentages of their total weight, not of the original ro g. of soil. There is a small loss in weight during analysis, mainly due to solution of carbonates. For brevity the silt-plus-clay content of a soil has here been referred to as its silt content. 
It is suggested that for marine soils the solution of carbonates is unnecessary, and may give a misleading result where large quantities of shell-fragments are present; but in most of these samples the calcium carbonate content was fairly low.

\section{Nomenclature}

Nomenclature is that of the Plymouth Marine Fauna (Marine Biological Assoc., 193I), but with the following alterations and additions:

Eteone longa (Fabricius). See Fauvel (1923).

Ophelia bicornis Savigny. See Fauvel (I927).

Spiophanes bombyx (Claparède). See Fauvel (1927).

Bathyporeia pilosa Lindström, and B. sarsi Watkin. See Watkin (1938).

Urothöe grimaldii Chevreux. See Chevreux \& Fage (1925).

Corophium arenarium Crawford. See Crawford (I937a).

Algae. Nomenclature in accordance with A Handbook of the British Seaweeds by Newton (193I).

Flowering plants are named in accordance with the Handbook of the British Flora by G. Bentham, revised by Sir J. D. Hooker, seventh edition, I924. The reference to Zostera hornemanniana Tutin is in Tutin (1936).

The spelling of place-names follows the Ordnance Survey: the names 'Bull Hill' and 'Pole Sands' being used in preference to Allen \& Todd's 'Bullhill' and 'Polesands'.

\section{DESCRIPTION OF THE TRAVERSES}

\section{Conditions}

\section{The Main Traverse}

Seven main stations at $100 \mathrm{ft}$. intervals were worked; at each two collections were made from $\frac{1}{4} \mathrm{~m} .{ }^{2}$ Some collections at intermediate positions were also made.

The general appearance of the traverse may be summarized as:

\begin{tabular}{|c|c|c|}
\hline I- IOO & $\rightarrow \mathrm{I}$ & Well-drained clean sand \\
\hline I & $\rightarrow \mathrm{I}+70$ & Moist clean sand \\
\hline $\mathrm{I}+70$ & $\rightarrow \mathrm{III}-\mathrm{IO}$ & Muddy sand with small pools. Arenicola casts numerous \\
\hline II - IO & $\rightarrow \mathrm{III}+\mathrm{II} \frac{1}{2}$ & Shallow stream running over sand \\
\hline $\mathrm{III}+\mathrm{II} \frac{1}{2}$ & $\rightarrow$ III +57 & Sand becoming muddier \\
\hline $\mathrm{III}+57$ & $\rightarrow \mathrm{III}+88$ & Soft mud with some sand \\
\hline III +88 & $\rightarrow \mathrm{IV}+\mathrm{I} 2$ & Soft mud with patches of Enteromorpha \\
\hline $\mathrm{IV}+\mathrm{I} 2$ & $\rightarrow \mathrm{IV}+87$ & Clayey mud \\
\hline $\mathrm{IV}+63$ & $\rightarrow \mathrm{IV}+67$ & Narrow stream \\
\hline $\mathrm{IV}+87$ & $\rightarrow \mathrm{VI}$ & Mud with Zostera spp. \\
\hline
\end{tabular}

(All descriptions are of the conditions at low tide.)

Analyses of the soil grades are given in Table I. The silt content rose gradually from $0 \cdot 7 \%$ at I-I00 to $2 \cdot 2 \%$ at II +67 . Beyond Station III there was a sharp rise, with a maximum of $22.6 \%$ at Station V. The small quantity of silt at Station III was probably due to the stream over the sand at this point. The proportions of the coarser grades are constant along the traverse; in all 
but one or two samples the greatest proportion consisted of 'fine sand' (0.22-0.02 mm.). Over $95 \%$ of the total was made up of grades below $0.5 \mathrm{~mm}$.

\section{Table I. Soll Grades on the Main Traverse, Expressed as PERCENTAGES BY WeIGHT}

The dimensions are those of the sieves used.

\begin{tabular}{|c|c|c|c|c|c|c|}
\hline Station & $>2 \mathrm{~mm}$ & $2-0.5 \mathrm{~mm}$ & $\begin{array}{c}0.5- \\
0.256 \mathrm{~mm} .\end{array}$ & $\begin{array}{c}0.256- \\
0.22 \mathrm{~mm} \text {. }\end{array}$ & $\begin{array}{c}0.22- \\
0.02 \mathrm{~mm} .\end{array}$ & $\begin{array}{l}\text { Silt and } \\
\text { clay }\end{array}$ \\
\hline $\mathrm{I}-\mathrm{IOO}$ & Few stones & $4 \cdot 6$ & $26 \cdot 6$ & $23 \cdot 9$ & $44 \cdot 2$ & 0.7 \\
\hline $\mathrm{I}-40$ & Very few stones & 0.5 & $9 \cdot 3$ & $12 \cdot 3$ & $77 \cdot 5$ & 0.3 \\
\hline I & Nil & $2 \cdot 8$ & $22 \cdot 2$ & $23 \cdot 2$ & $5 \mathrm{I} \cdot 7$ & 0.05 \\
\hline $\mathrm{I}+8$ & Nil & I. 4 & $17 \cdot 2$ & $25 \cdot 3$ & $56 \cdot 0$ & 0.35 \\
\hline$I+33$ & Nil & I.6 & I $7 \cdot 8$ & 25.0 & $55 \cdot 0$ & 0.7 \\
\hline$I+67$ & Nil & $\mathrm{I} \cdot 2$ & 19.9 & $29 \cdot I$ & $49 \cdot 2$ & 0.7 \\
\hline II & Nil & $I \cdot I$ & I3.9 & $2 \mathrm{I} \cdot 2$ & $62 \cdot 2$ & I. 6 \\
\hline $\mathrm{II}+33$ & Nil & 0.7 & 9.4 & I5.9 & $72 \cdot 6$ & $I \cdot 35$ \\
\hline II +67 & Nil & 0.8 & I0.8 & I6.5 & $69 \cdot 7$ & $2 \cdot 2$ \\
\hline III & Nil & $\mathrm{I} \cdot 7$ & I0.4 & I5.8 & $70 \cdot 7$ & $\mathrm{I} \cdot 5$ \\
\hline III +33 & Nil & $I \cdot I$ & $3 \cdot 2$ & $6 \cdot 0$ & $82 \cdot 7$ & 6.9 \\
\hline III +67 & Nil & 0.7 & $6 \cdot 2$ & $7 \cdot 9$ & $76 \cdot 8$ & $8 \cdot 4$ \\
\hline IV & Nil & 0.2 & $2 \cdot 7$ & $3 \cdot 3$ & $77 \cdot 3$ & 16.6 \\
\hline $\mathrm{IV}+33$ & Nil & 0.6 & $7 \cdot 5$ & $8 \cdot 9$ & $73 \cdot 6$ & $9 \cdot 4$ \\
\hline IV + 67 & Nil & 0.6 & $5 \cdot 5$ & $5 \cdot 1$ & $73 \cdot 8$ & 15.0 \\
\hline V & $\begin{array}{c}\text { Nil } \\
\text { Few shellfragments }\end{array}$ & 0.8 & 47 & 3.0 & $68 \cdot 9$ & $22 \cdot 6$ \\
\hline VI & Few shell fragments & $6 \cdot 8$ & I8.0 & 10.4 & $53 \cdot 8$ & II $\cdot 2$ \\
\hline
\end{tabular}

The traverse was situated at about half-tide mark, but sloped upwards towards Stations I and I-I00 which were a little below mean high-water mark of neap tides. These stations were not covered at extreme neap tides. Stations III, IV, V and VI were at about the same level (Fig. 3).

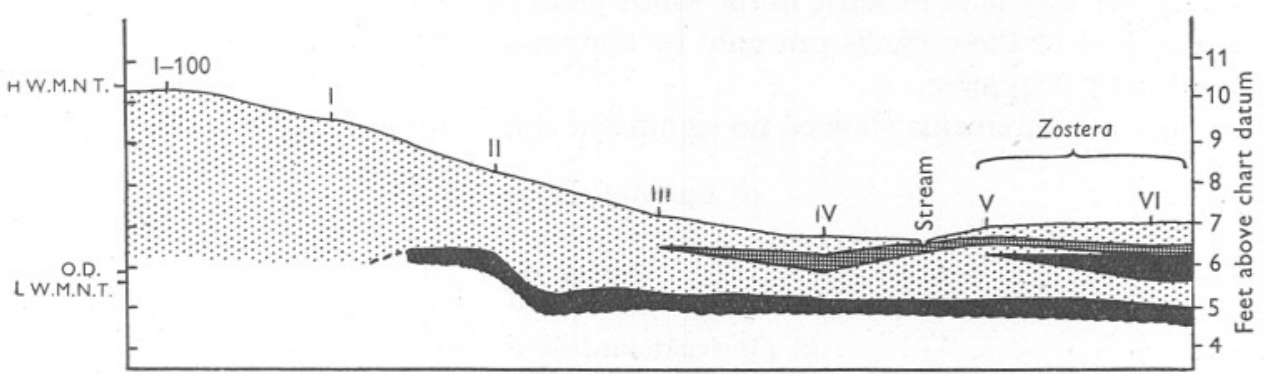

Fig. 3. Profile of the main traverse. The distance between stations is roo ft., and the vertical scale is greatly exaggerated. The white area is below the depth investigated.
Mud or sand.

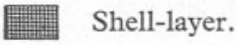
aㅡ. Clay.

Much of the traverse lay on top of a bed of clay, which was quite near the surface at Stations V and VI. In addition, Stations III-VI inclusive overlay a bed of shell remains at a depth of about a foot. The shells were of the same species as those now living in this area, consisting mainly of Hydrobia, Cardium, Scrobicularia and Macoma. 
The greater height of the bank at Stations I and I-I00 was presumably due to deposition of sand from Warren Point in this area. It was not possible to find any trace of the original surface of the bank, and it was presumed that the new sand had become mingled with the old layer. The depth to which the bank had been inundated was, however, determined by the discovery of a wood post in the sand. (Position marked by a cross in Fig. 2.) This post had been driven into a bed of clay on the original bank and was half covered by sand. On it were found empty shells of Balanus sp. and Chthalmus stellatus at a maximum depth of $26 \mathrm{in}$. below the surface of the sand. The post appeared fairly new and had probably been erected within the past ro years. The lower end of the post was embedded in clay, and it seemed unlikely that it had been disturbed since its original erection. Thus sand had probably accumulated here to a depth of about 30 in. The traverse area is clearly at the edge of the region covered by sand, and Station I- I00 had probably been covered by about $2 \mathrm{ft}$. of sand, and Station I and possibly also Station II, to a lesser depth.

The nature of the banks before the recent changes is uncertain. The Ordnance Survey Map of 1903-4 marks the area inside Warren Point as 'mud', whereas that of 1935 marks it as 'sand and mud'. It had probably become more sandy as the Outer Warren narrowed, being finally inundated by clean sand about 1943 when the breach occurred.

Currents in the Salthouse Lake area were slight, but there was some scour in the bed of the stream at low tide. There seemed to be no significant differences in current action along the traverse. Mud stirred up by waves and currents may tend to settle in the sandy areas of the traverse, and the present condition of these banks can only be temporary. Wave action in this area is normally negligible.

$\mathrm{pH}$ measurements showed no significant differences along the traverse.

\begin{tabular}{rll}
\multicolumn{1}{c}{ (i) Interstitial water } & $\mathrm{pH}$ \\
12. vii. 47, low tide & Station I & $7 \cdot 8$ \\
& Station II & $7 \cdot 8-8 \cdot 0$ \\
& Station III & $8 \cdot 0$ \\
(ii) pH determined electrically \\
6. viii. 47, low tide & Station II & $7 \cdot 3$ \\
& Station IV & $8 \cdot 3$ \\
& Station VI & $7 \cdot 8$ \\
14. viii. 47, low tide & Station I & $7 \cdot 5$ \\
& Station II & $7 \cdot 5$ \\
& Station III & $7 \cdot 9$ \\
& Station IV & $7 \cdot 9$ \\
& Station V & $7 \cdot 5$
\end{tabular}

Salinity and temperature. Miscellaneous salinity records showed that the salinity in the area was near-marine, there being no differences along the traverse (except, perhaps, during rain). On II July 1947 (high tide II.I5 a.m., 
height $9 \mathrm{ft} .6$ in.) the surface salinity of water covering certain stations was measured:

$\begin{array}{cccc}\text { Station } & \text { Salinity }(\% \text { oo } & \text { Depth of water (in.) } & \text { Time (p.m.) } \\ \text { I } & 34 & 4 & \text { 12.20 } \\ \text { III } & 34 & 24 & \text { I.00 } \\ \text { VI } & 34 & \text { I5 } & \text { r.15 }\end{array}$

On 2 days, at spring and neap tides, all-day readings of conditions were made: I9 August I947. High tide: 8.37 a.m. I3 ft. 2 in. (spring tide); 8.45 p.m. I3 ft. 2 in. A fine sunny day, but with some haze. Calm sea. Gentle breeze. There had been no rain for the previous fortnight and the River Exe was very low. Records were made of:

(i) The temperature in the soil at each station at depths of $\frac{1}{2}$ and 3 in., when uncovered by the tide.

(ii) The temperature and salinity at Station III, taken in the overlying water at high tide, and in a small pool at low tide.

(iii) Temperature and salinity of the surface water in the main channel by Bull Hill Bank.

(iv) Duration of exposure of each station at low tide.

(v) Depth of the water-table in the soil.

(vi) Air temperature.

The results are summarized in Tables II, III, IV, XI, XII and Figs. 4 and 5. The readings show:

The surface $\left(\frac{1}{2}\right.$ in.) soil rose to a high temperature, $26.5^{\circ} \mathrm{C}$. being the maximum recorded. The temperatures attained by the different types of soil were very similar. Thus at 4.15 p.m. the maximum soil temperature was $26^{\circ} \mathrm{C}$. and the minimum $25^{\circ} \mathrm{C}$.

A temperature gradient is set up in the soil during the day, the temperature at 3 in. depth being about $2^{\circ} \mathrm{C}$. lower than in the surface soil. In the evening the soil cools and the gradient is reversed. At Station III the temperature ranged from $19^{\circ} \mathrm{C}$. at high tide to $27.25^{\circ} \mathrm{C}$. in a pool at low tide. The temperature changes occurring when the tide covered this station again in the evening were not as sudden as might be expected, as the water had already been warmed as it flowed over banks in the vicinity. At low tide the salinity rose from 34.5 to $38 \%$ as a result of evaporation.

Station I was uncovered for over $7 \frac{1}{2} \mathrm{hr}$., whereas Stations II-VI were each uncovered for about $6 \mathrm{hr}$. On a neap tide the relative differences in the periods of emergence would be much greater.

Observations on the water-table showed that it was at the surface at all stations except I-I00, I and II. Drainage at Station I was very much more thorough than at II. The better drainage at this end of the traverse may be due to the nature of the soil, the greater height of these stations, or to the absence of a clay layer at any significant depth.

In the main channel the temperature ranged from 18.75 to $22.5^{\circ}$; the highest temperature being at low tide. The salinity showed a corresponding fluctuation, being $35 \%$ at high tide, and $32.5 \%$ at low tide. For most of the tidal cycle the salinity was over $34 \%$, there being a marked drop for an hour or two each side of low water.

A set of readings was also taken on I2 August 1947 on a neap tide, results being similar to those above. In addition it was noted that:

The salinity of the water in Salthouse Lake was found to drop to about $19 \%$ for about an hour at low water. The fresh-water inflow of this stream is small, and does not appear to exert any local influence on the fauna. 
At Station I the water-table dropped to I3 in. depth, as compared with II in. on a spring tide. This increased drainage was probably due to the absence of water flowing down the beach from regions above high neap-tide level. Thus on spring tides the quantity of water draining down from these areas prevents the water-table from dropping as much as on neap tides.

\section{Table II. Temperature Readings on the Main Traverse, I9 August 1947}

Temperatures $\left({ }^{\circ} \mathrm{C}\right)$ were recorded at depths of $\frac{1}{2}$ and 3 in. below the soil surface. A dash indicates that the station was covered by water.

\begin{tabular}{|c|c|c|c|c|c|c|c|c|c|c|c|c|c|}
\hline \multirow[b]{2}{*}{ Time } & \multirow{2}{*}{$\begin{array}{l}\text { Air } \\
\left(\left(^{\circ}\right)\right.\end{array}$} & \multicolumn{2}{|c|}{ I } & \multicolumn{2}{|c|}{ II } & \multicolumn{2}{|c|}{ III } & \multicolumn{2}{|c|}{ IV } & \multicolumn{2}{|c|}{$\mathrm{V}^{\circ}$} & \multicolumn{2}{|c|}{ VI } \\
\hline & & $\frac{1}{2}$ in. & 3 in. & $\frac{1}{2}$ in. & 3 in. & $\frac{1}{2}$ in. & 3 in. & $\frac{1}{2}$ in. & 3 in. & $\frac{1}{2}$ in. & 3 in. & $\frac{1}{2}$ in. & 3 in. \\
\hline $7.30 \mathrm{a} . \mathrm{m}$. & 22 & - & - & - & - & - & - & - & - & - & - & - & - \\
\hline 8.00 & $20 \cdot 25$ & - & - & - & - & - & - & - & - & - & - & - & - \\
\hline 9.30 & 20.25 & - & - & - & - & - & - & - & - & - & - & - & - \\
\hline 10.00 & 2 & - & - & - & - & - & - & - & - & - & - & - & - \\
\hline II .00 & 2.25 & - & - & - & - & - & - & - & - & - & - & & - \\
\hline I2 noon & 23.25 & $24 \cdot 75$ & 22 & 24 & $2 \mathrm{I} \cdot 75$ & - & - & - & - & $2 \mathrm{I} \cdot 75$ & $20 \cdot 5$ & $22 \cdot 25$ & 2 I \\
\hline I.05 p.m. & 2 & & 24 & 25 & 23 & $25 \cdot 5$ & 23.5 & 25 & $22 \cdot 5$ & 25 & $22 \cdot 5$ & & $22 \cdot 5$ \\
\hline 2.10 & 25 & & & 26 & 24 & & 24 & & 24 & & 24 & & 24 \\
\hline 3.15 & $21 \cdot 5$ & $25 \cdot 75$ & $24 \cdot 75$ & 26 & $24 \cdot 5$ & 26.5 & 25 & $26 \cdot 25$ & 25 & 26 & $24 \cdot 5$ & $26 \cdot 25$ & $24 \cdot 5$ \\
\hline 4.15 & & 25 & $24 \cdot 5$ & 26 & $24 \cdot 75$ & 25.5 & 25.5 & & $24 \cdot 5$ & & 24 & & 24 \\
\hline 5.15 & $21 \cdot 5$ & 23.5 & 24 & 23 & 23.5 & 23.5 & 24 & 23.5 & 24 & 23.25 & 23.5 & 23.5 & 24 \\
\hline 6.10 & & 23 & 23 & $22 \cdot 5$ & 23 & & 10 & 年 & - & - & - & 23 & 23.5 \\
\hline
\end{tabular}

Table III. Depth of the Water-Table Below the Soll Surface, I9 August 1947

At Stations II +33 to VI the water-table was at the surface at all times. Station I was uncovered at about II a.m. and Station II at II.50 a.m. S, water-table at surface.

$\begin{array}{lccc}\quad \text { Time } & \text { I (in.) } & \text { I +50 (in.) } & \text { II (in.) } \\ \text { II.20 a.m. } & \text { S } & -\mathrm{S} & - \\ \text { II.40 } & \frac{\mathrm{S}}{\mathrm{S}} & \mathrm{S} & \overline{\mathrm{S}} \\ \text { I2 noon } & \mathrm{S} & \mathrm{S} & \frac{1}{2} \\ \text { I.05 p.m. } & 5 & \frac{1}{4} & \mathrm{I} \\ 2.20 & 8 & \mathrm{I} & \mathrm{I} \\ 3.15 & \mathrm{I} & \frac{3}{4} & \mathrm{I} \\ 4.10 & \mathrm{IO} & 6 \frac{1}{2} & \mathrm{I} \\ 5.15 & \mathrm{II} & 6 \frac{1}{2} & \mathrm{I}\end{array}$

Table IV. Duration of Exposure at Low Tide of Stations on Main Traverse, i9 August I947

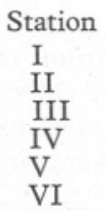

Time

$7 \frac{1}{2} \mathrm{hr} .+$ $6 \mathrm{hr} .24 \mathrm{~min}$. c. $6 \mathrm{hr}$. 5 hr. $50 \mathrm{~min}$. $6 \mathrm{hr}$. $15 \mathrm{~min}$. $6 \mathrm{hr}$. $17 \mathrm{~min}$.

There are a number of other factors, not readily measurable, which may affect distribution. The oxygen content of the soil cannot be easily determined in the field; the degree of aeration of the soil can, however, be measured by the depth of the 'black-layer'. Bruce (1928) has shown that the black-layer 
is produced by ferrous sulphide, which is oxidizable to ferric oxide. The top of the black-layer is a level at which there is equilibrium between sulphide production at a depth in the soil and oxidation in the more superficial layers.

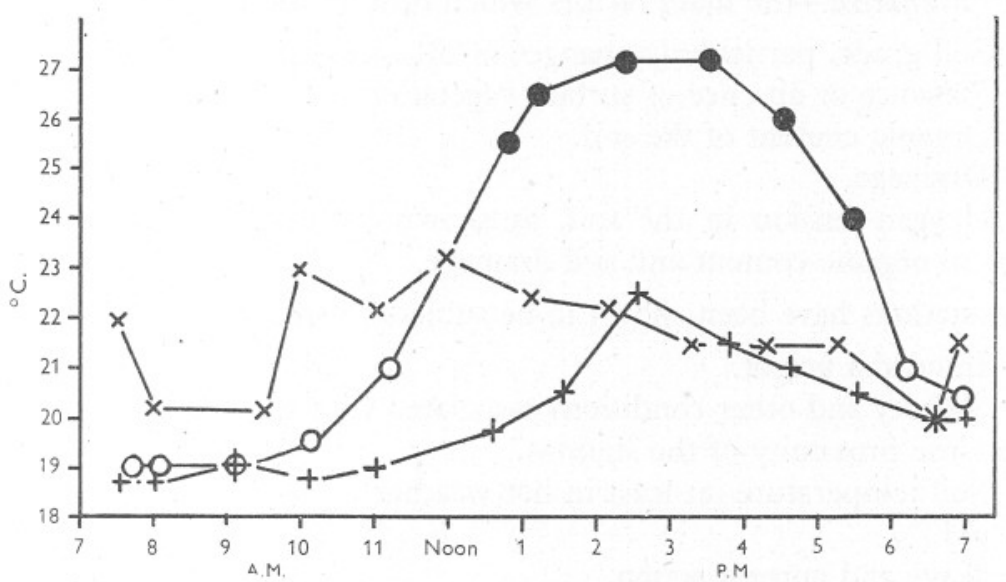

Fig. 4. Temperatures at Station III, and in the channel near Bull Hill, I9. viii. 47. - - , water covering III; - - - , pool at III (low tide); $-\times-$, air temperature; -+- , main channel.

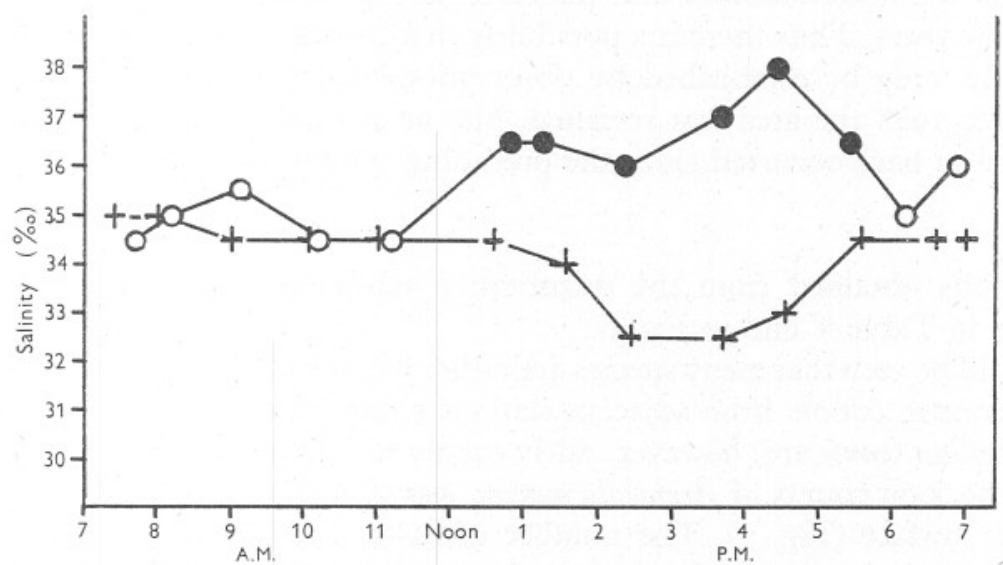

Fig. 5. Salinities at Station III, and in the channel, I9. viii. 47. $-\mathrm{O}-$, water covering III; - -

The black-layer tends to occur where there is little circulation (of water) through the sand, or where much organic matter occurs. The black-layer was within an inch or so of the surface from Stations II to VI, but was at a greater depth in the well-drained areas. The smell of hydrogen sulphide was not noticeable when any of the muds were disturbed, so that it is unlikely that extremely anaerobic conditions occurred anywhere on the traverse. 
There seems to be no satisfactory method of estimating the organic content of marine soils, but it can be assumed that the organic content of the mud covered by Zostera was very much higher than elsewhere.

To summarize-the main factors which differed along the traverse were:

(I) Soil grade, particularly changes in silt content.

(2) Presence or absence of surface vegetation.

(3) Organic content of the soil.

(4) Drainage.

(5) Oxygen-tension in the soil, as shown by the 'black-layer'. This is related to organic content and soil drainage.

The stations have been shown to be subject to similar conditions of:

(I) Intertidal height.

(2) Salinity and other conditions associated with the overlying water-due to the close proximity of the stations.

(3) Soil temperature (at least in hot weather).

(4) $\mathrm{pH}$.

(5) Wave and current action.

Another factor to be considered is the age of the various banks. Stations III-VI inclusive are evidently long established, but sand has recently accumulated at the other stations, and the communities must have developed in the past few years. Thus there is a possibility that succession may be taking place; this can only be established by observations over a number of years. In October 1948 the area was revisited, but no marked changes in the fauna seemed to have occurred since the preceding summer.

\section{Fauna}

Results obtained from the quantitative sampling along the traverse are shown in Table $\mathrm{V}$ and in Fig. 6.

It will be seen that many species are rather patchily distributed, considerable variations in counts from adjacent stations being experienced. A few species, e.g. Tellina tenuis are, however, fairly evenly distributed.

A check on counts of Arenicola marina was provided by the density of casts on the surface (Fig. 7). The number of casts of this species per m..$^{2}$ were counted at intervals of $6 \mathrm{ft}$. along the traverse, corrections being made where one worm appeared to have produced more than one cast. The area was sufficiently calm for casts to persist for several days, and the numbers agreed well with those found in the digging. It would appear that a $\frac{1}{4} \mathrm{~m} .{ }^{2}$ sample is adequate for assessing the numbers of a comparatively sparse animal such as Arenicola.

Collections were made over a period of 2 months (July and August 1947) so that it is possible that some differences were due to seasonal changes. No very great differences are shown, however, between, for example, the fauna 


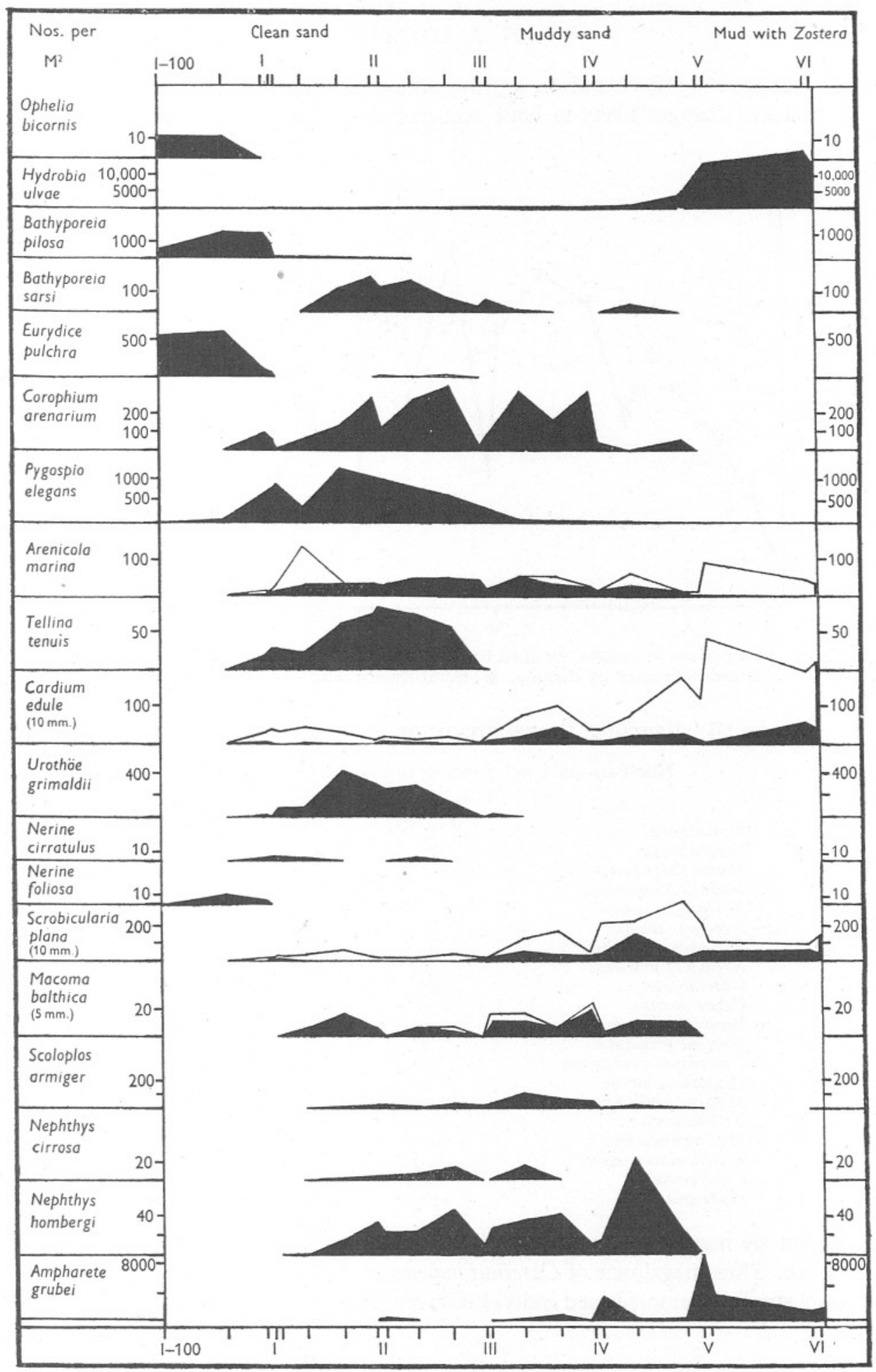

Fig. 6. The distribution of certain species on the main traverse. Small individuals are indicated by the outlined areas; adults by the solid black areas. The figures in brackets under the names of lamellibranchs indicate the length measurement dividing small individuals from adults. 
at Station $\mathrm{I}+3$ (collected on 3 July) and of $\mathrm{I}+8$ (collected on 22 August). The main changes likely to have occurred are in the sizes of the animals, as

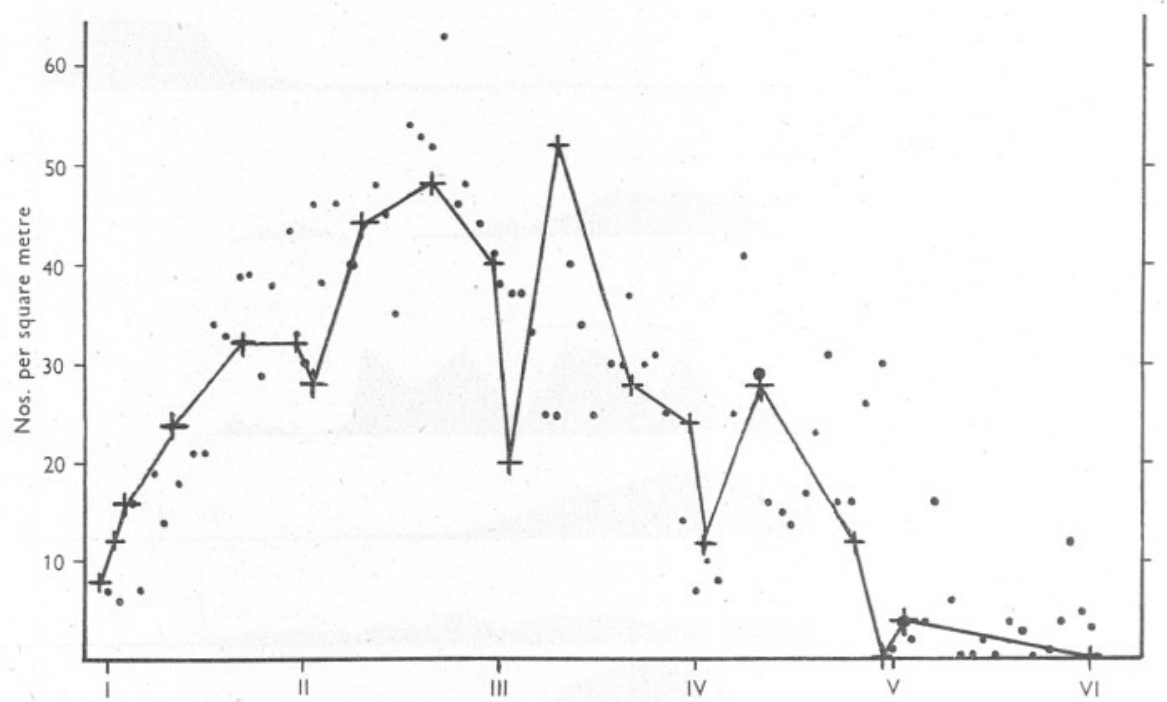

Fig. 7. Comparison of results obtained by counts of casts of adult Arenicola marina, and of numbers obtained by digging. - , numbers of casts; -+- , worms dug up.

Table VI. Vertical Distribution of Species in the Sand at I +30 Numbers per $\frac{1}{4} \mathrm{~m} .^{2} j$, young individuals; + , present.

$\begin{array}{lr}\text { Nemertinea } & 7 \\ \text { Eteone longa } & \mathrm{IO} \\ \text { Nereis diversicolor } & \mathrm{I} \\ \text { Nephthys hombergi } & - \\ \text { Nerine cirratulus } & - \\ \text { Pygospio elegans } & + \\ \text { Spiophanes bombyx } & - \\ \text { Arenicola marina } & 26 j \\ \text { Clitellio ater } & 85 \\ \text { Other worms } & - \\ \text { Bathyporeia pilosa } & 6 \\ \text { Urothöe grimaldii } & 2 \\ \text { Corophium arenarium } & \mathrm{I} 6 \\ \text { Dipterous larvae } & 6 \\ \text { Mytilus edulis spat. } & \mathrm{I} \\ \text { Tellina tenuis } & 6 \\ \text { Macoma balthica } & 2 \\ \text { Scrobicularia plana } & \mathrm{I} j \\ \text { Cardium edule } & \mathrm{II} \\ \text { Hydrobia ulvae } & \mathrm{I} 36\end{array}$

$\begin{array}{cr}4-8 \text { in. } & 8-\mathrm{I} 2 \text { in. } \\ \text { I } & - \\ \text { I } & - \\ \text { I } & - \\ 2 j+5 & \text { I } \\ 2 & \text { I } \\ \text { I } & - \\ \text { I } & - \\ - & \text { I } \\ - & - \\ - & - \\ - & - \\ - & -\end{array}$

shown by measurements of the shells of molluscs and in the settlement of larvae. Thus megalopae of Carcinus maenas were found in early July, whereas only small metamorphosed individuals were found in late July and in August. 
1 ABLE V. 1 HE FAUNA OF THE MAIN AND INTERTDALL, 1 raverses

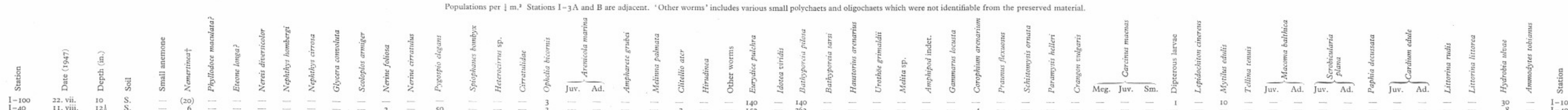
(n) 
The vertical distribution of species at Station $\mathrm{I}+30$ is shown in Table VI; it will be seen that practically all species occur in the top 4 in., notable exceptions being Arenicola marina and Urothöe grimaldii.

The close proximity of the various types of ground may also affect the distribution of certain species. Individuals may stray from their typical habitat (perhaps as a result of 'population pressure') so that in time a species will come to colonize all suitable grounds. This spreading tendency presumably operates continually and will result in a fringing zone where individuals may occur on quite atypical grounds. The extent of this zone will vary with the migratory ability of the species and the degree of unsuitability of the ground to be traversed. The outstanding example here was Hydrobia ulvae, normally inhabiting the mud, particularly the Zostera beds, but which is continually endeavouring to extend its range so that specimens occur even on the sandy grounds. They would not occur there but for the contiguity of their normal habitat.

The fauna of the main traverse may be arbitrarily divided into a number of zones:

(I) Fauna of clean loose sand. Stations I-IOO and I-40. The silt content was less than $\mathrm{I} \%$ and the grade of sand was coarser than at other stations on this traverse. The sand was very well drained, there being no black-layer near the surface.

Typical species were (Station $\mathrm{I}-40$ ):

$\begin{array}{lclc} & \text { Per m. }{ }^{2} & & \text { Per m. }{ }^{2} \\ \text { Ophelia bicornis } & \text { I2 } & \text { Bathyporeia pilosa } & \text { I448 } \\ \text { Nerine foliosa } & \text { I2 } & \text { Corophim arenarium } & \text { I6 } \\ \text { Pygospio elegans } & \text { A few } & \text { Hydrobia ulvae } & 32 \\ \text { Eurydice pulchra } & \text { 6I2 } & & \end{array}$

(2) Fauna of firm moist sand. Stations I-III. The sand was rather finer than at the previous stations. The silt content rose from $0.05 \%$ to a maximum of $2 \cdot 2 \%$ at II +67 . The bank sloped down gently, so that while Stations I to I +67 were fairly well drained, the subsequent stations had standing water on the surface. A black layer usually occurred within a few inches of the surface.

Typical species were (Station II +33):

$\begin{array}{lclc} & \text { Per m. }{ }^{2} & & \text { Per m. } .^{2} \\ \text { Nephthys hombergi } & 24 & \text { Urothöe grimaldii } & 268 \\ \text { N. cirrosa } & 8 & \text { Corophium arenarium } & 280 \\ \text { Scoloplos armiger } & \text { I2 } & \text { Tellina tenuis } & 76 \\ \text { Pygospio elegans } & \text { Common } & \text { Macoma balthica } & 8 \\ \text { Arenicola marina } & 44 & \text { Cardium edule } & 8 \text { young } \\ \text { Bathyporeia sarsi } & \mathrm{I} 64 & \text { Hydrobia ulvae } & 448\end{array}$

Ophelia bicornis and Nerine foliosa were no longer present, and Eurydice was much less frequent. Bathyporeia pilosa had been replaced by B. sarsi, probably due to the fall in height. According to Watkin (1938) B. pilosa is restricted to a narrow zone at about H.W.M.N.T., whereas $B$. sarsi has a wider range extending down to below low-water mark. A number of species appeared at 
about Station I and extended almost the length of the traverse; e.g. Nephthys hombergi, Scoloplos armiger, Scrobicularia plana and Cardium edule. But Bathyporeia sarsi, Tellina, Urothöe and Nerine cirratulus were restricted to the clean sand of this zone.

(3) Muddy sand. Stations III +33 to IV +80 . This was a transitional zone from sand to mud. At Station III +33 the silt content was $6.9 \%$, and a maximum of $16.6 \%$ silt occurred at Station IV. The other grades of soil were in very similar proportions to that found elsewhere in the traverse. The rise in silt content seems to be the cause of the absence of Bathyporeia, Tellina, Urothöe and Nerine; but the species extending into this zone usually show a higher density than on the clean sand.

Typical species were (Station IV +3):

$\begin{array}{lclc} & \text { Per m. }{ }^{2} & & \text { Per m. }{ }^{2} \\ \text { Nephthys hombergi } & \text { I6 } & \text { Corophium arenarium } & 44 \\ \text { Glycera convoluta } & 20 & \text { Macoma balthica } & 4 \\ \text { Pygospio elegans } & \text { Present } & \text { Scrobicularia plana } & \text { I80 young and 40 adult } \\ \text { Arenicola marina } & \text { I2 } & \text { Cardium edule } & 8 \text { young and 28 adult } \\ \text { Ampharete grubei } & 3552 & \text { Hydrobia ulvae } & 620 \\ \text { Melinna palmata } & 8 & & \end{array}$

Large numbers of Ampharete occur; this species being most abundant where the silt content is high. Pygospio occurred in small numbers, and thus inhabits a wide range of soils.

(4) Mud with Zostera. Stations V and VI. The soil contained about IO- $20 \%$ of silt, and was of a rather clayey consistency. When walking over it, one's feet sunk in only a few inches. Holes dug in the mud persisted for months after digging. The surface of the mud was covered by a dense growth of $Z$. hornemanniana Tutin and $Z$. nana Roth, which provided a refuge for numerous small Carcinus maenas and Hydrobia ulvae. Small specimens of Arenicola marina were abundant. The burrowing fauna was, if anything, a little less dense than on the muddy sand. Macoma, Scoloplos and Nephthys hombergi were absent.

Typical species were (Station $\mathrm{V}+3$ ):

Per m. ${ }^{2}$

Arenicola marina

Ampharete grubei

Carcinus maenas

Scrobicularia plana

Conditions

88 small and 4 adult
3984
160
48 young and 60 adult

Per m. ${ }^{2}$

Cardium edule

Littorina rudis

L. littorea

$\begin{array}{lr}\text { L. littorea } & 84 \\ \text { Hydrobia ulvae } & 13,280\end{array}$

I 3,280

284 young and 4 adult

This was at right angles to the main traverse, crossing it at Station II, which is identical with Station E. Stations were at Ioo ft. intervals and were designated A, B, C . . H. 'A' was near high-water mark, and ' $\mathrm{H}$ ' at lowwater mark. Stations A, B and C were on gravel, with some admixture of sand. The fauna at these stations was imperfectly sampled owing to difficulties in 
sieving. From $\mathrm{C}+\mathrm{I} 2$ to $\mathrm{H}$ the soil was fairly clean moist sand, overlying the bed of clay. Grade analyses showed a silt content of under I $\%$ for stations from D downwards (Table VII).

Table VII. Soll Grades on the Intertidal Traverse, Expressed as Percentages by Weight

\begin{tabular}{|c|c|c|c|c|c|c|}
\hline Station & $>2 \mathrm{~mm}$ & $2-0.5 \mathrm{~mm}$. & $0.5-0.256 \mathrm{~mm}$ & $0.256-0.22 \mathrm{~mm}$. & $0.22-0.02 \mathrm{~mm}$ & $\begin{array}{l}\text { Silt and } \\
\text { clay }\end{array}$ \\
\hline A & Many stones & $24 \cdot 3$ & $44 \cdot 5$ & I9. 6 & II $\cdot I$ & 0.5 \\
\hline $\mathrm{B}$ & Few stones & $5 \cdot 7$ & 38.7 . & $29 \cdot 7$ & 24.0 & $2 \cdot 0$ \\
\hline C & Few stones & 2.5 & 9.3 & 10.0 & $73 \cdot 8$ & 4.4 \\
\hline $\mathrm{D}$ & Nil & $I \cdot 6$ & 19.5 & $25 \cdot 0$ & 53.0 & $I \cdot 0$ \\
\hline $\mathrm{E}$ & Nil & $I \cdot I$ & 13.9 & $2 I \cdot 2$ & $62 \cdot 2$ & $I \cdot 6$ \\
\hline $\mathrm{F}$ & $\mathrm{Nil}$ & 0.8 & I3.9 & $26 \cdot I$ & $58 \cdot 7$ & 0.6 \\
\hline G & Nil & 0.4 & $8 \cdot 4$ & $28 \cdot 9$ & $6 r \cdot 3$ & 0.9 \\
\hline $\mathrm{H}$ & Nil & 0.2 & $4 \cdot 5$ & 16.5 & $77 \cdot 7$ & $I \cdot 0$ \\
\hline
\end{tabular}

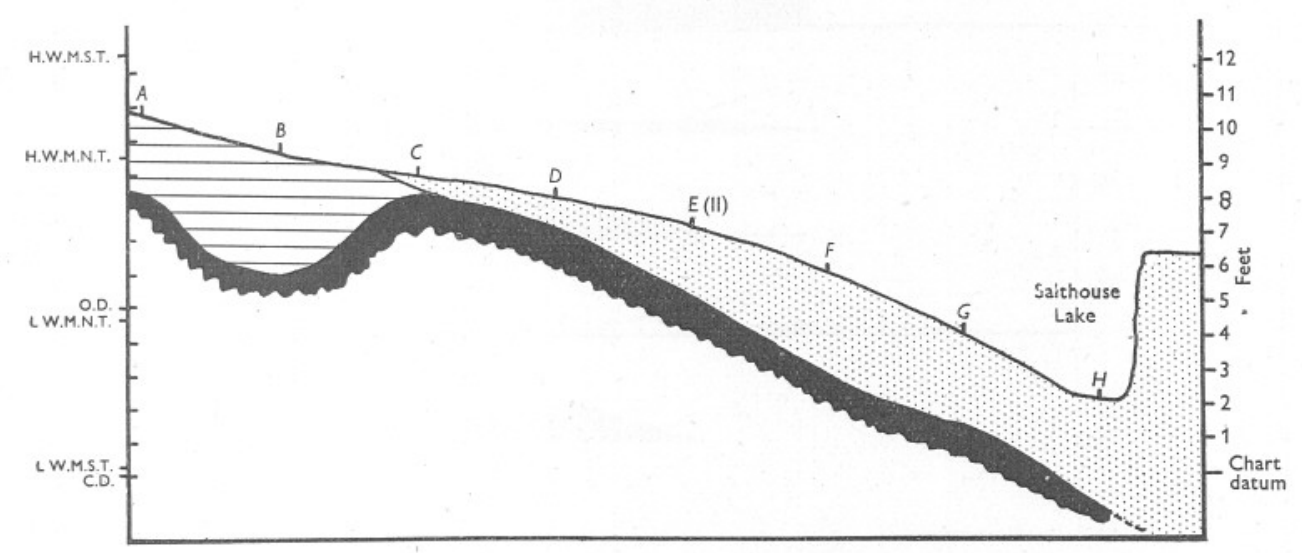

Fig. 8. Profile of the intertidal traverse. Vertical scale greatly exaggerated. Interval between stations is $100 \mathrm{ft}$. The white area is below the depth investigated.
Sand.
ए Gravel.
질 Clay.

The profile of the traverse is shown in Fig. 8. The bank sloped down to Salthouse Lake, so that there was little scouring of the banks near low water. This is in contrast to banks adjacent to the main channel which are exposed to a considerable tidal stream. The water-table was at or near the surface at all stations, and a black-layer was usually present at a depth of a few inches. Other conditions were similar to those to which the main traverse was exposed.

$\mathrm{pH}$ was determined electrically from samples taken at low tide on 2I August I947:

$\begin{array}{llll} & \mathrm{pH} & & \mathrm{pH} \\ \mathrm{A} & 7 \cdot 9 & \mathrm{E} & 7 \cdot 5 \\ \mathrm{~B} & 7 \cdot 9 & \mathrm{~F} & 7 \cdot 8 \\ \mathrm{C} & 7 \cdot 7 & \mathrm{G} & 7 \cdot 8 \\ \mathrm{D} & 7 \cdot 8 & \mathrm{H} & 8.0\end{array}$




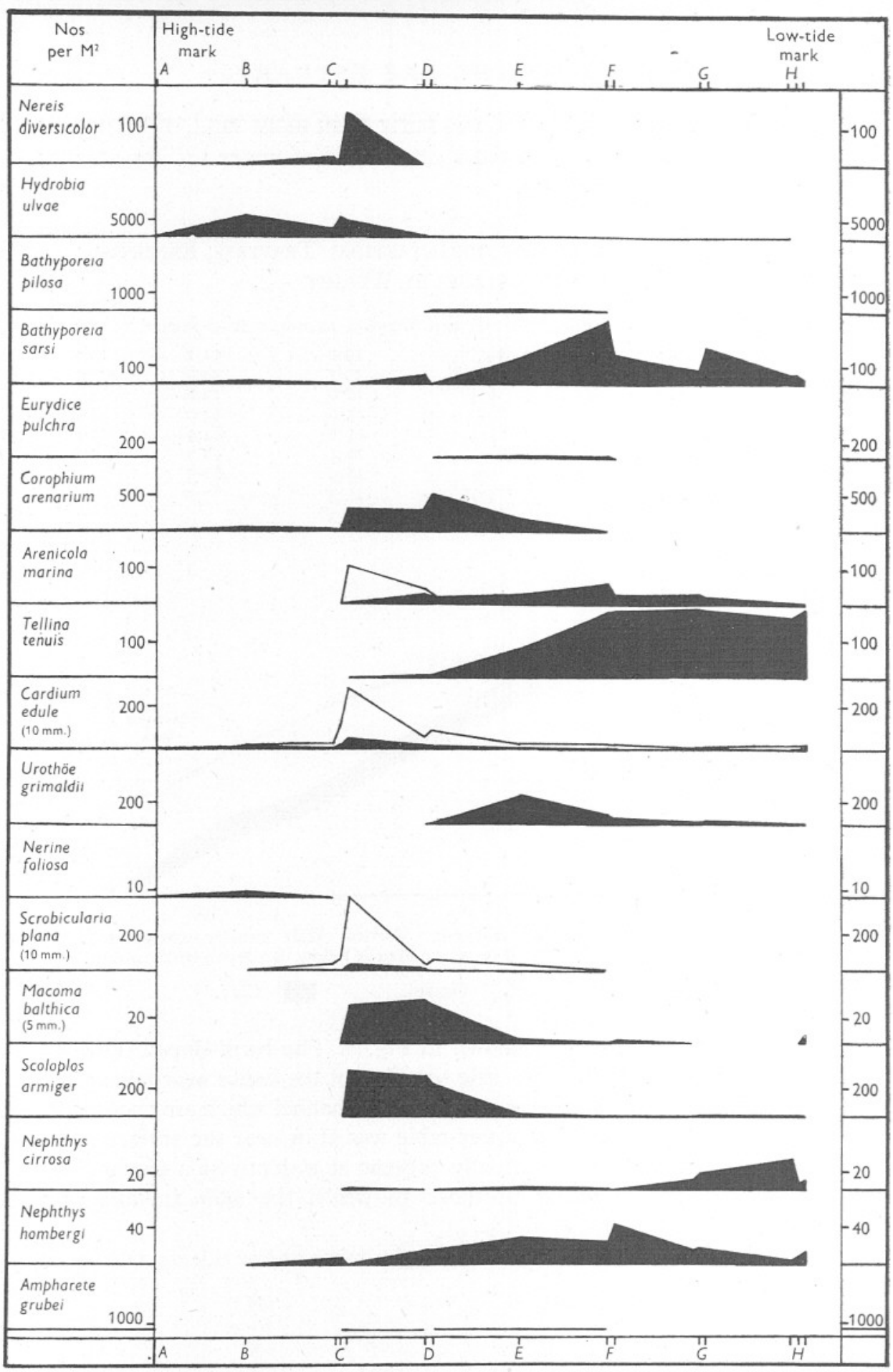

Fig. 9. Distribution of certain species on the intertidal traverse. For explanations see Fig. 6. Station ' $E$ ' is the average of numbers from Stations II -3 and II +3 . 


\section{Fauna}

The results obtained from quantitative sampling are shown in Table $\mathrm{V}$ and in Fig. 9. Only one collection was made at Stations A and B; and additional collections were made at $\mathrm{C}+\mathrm{I}_{5}$ and $\mathrm{H}+\mathrm{I}_{5}$, the latter being in the bed of Salthouse Lake. No other intermediate stations were worked.

The stations are too few to give a detailed picture of the distribution of the fauna, the object of these collections being to determine the intertidal distribution of species occurring in the main traverse. At Stations A, B and C the fauna was poor, especially in burrowing species. At $\mathrm{C}-3$ typical species were:

Nereis diversicolor Nephthys hombergi Corophium arenarium Larval Diptera Scrobicularia plana

\section{Per $\mathrm{m}^{2}$}

20
8
24
44
I6 young

Per . $^{2}$

Cardium edule Littorina rudis L. littorea Hydrobia ulvae $\quad 2468$

At Station C + I5, off the edge of the gravel, many species were abundant. The silt content was probably about $3 \%$, but was not determined. Small individuals of Arenicola, Cardium and Scrobicularia were very abundant. Typical species included:

Nereis diversicolor
Nephthys hombergi
Scoloplos armiger
Arenicola marina
Corophium arenarium
Mytilus edulis
Macoma balthica
Scrobicularia plana
Cardium edule
Hydrobia ulvae

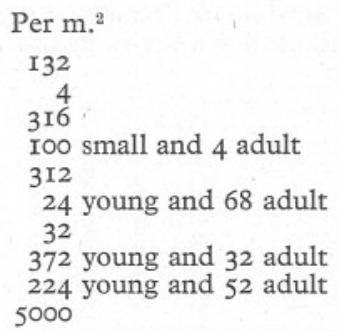

The intertidal distribution of species is discussed on pp. 218-28. It is apparent that most of the species encountered have a fairly wide intertidal range, so that the small differences in height occurring along the main traverse would have little effect on their distribution.

The distribution of the following species may, however, be affected by small changes in height: Nereis diversicolor occurred at about H.W.M.N.T., and was consequently scarce on the main traverse, which was at a slightly lower level. Bathyporeia pilosa, Eurydice pulchra and Nerine foliosa occurred only at about half-tide mark, and this may account for their occurrence only at the higher stations on the main traverse. Drainage may also be an important factor in determining their distribution.

\section{Bull Hill Bank}

This was a bank of clean sand in the middle of the estuary near Dawlish Warren. The bank was scoured by strong currents, and to a lesser extent by waves; the surface of the sand being consequently furrowed, and the edge 
facing the main channel sloped away steeply. The top was at about half-tide mark, and was fairly level.

The sand was rather coarser than that from Salthouse Lake. A sample from the top of the bank (from Station $\mathrm{BH}+\mathrm{IO0}$ ) giving on analysis:

$\begin{array}{cccc}(\mathrm{mm} .) & (\%) & (\mathrm{mm} .) & (\%) \\ >2 & - & 0.256-0.22 & 30 . \mathrm{I} \\ 2-0.5 & 5 . \mathrm{I} & 0.22-0.02 & 10.3 \\ 0.5-0.256 & 54.0 & \text { Silt and clay } & 0.5\end{array}$

Independent analyses of the sand from Bull Hill Bank and Salthouse Lake are given by Wilson (1948).

There was no black-layer in the soil, which was very well drained, except near low-water mark, where it remained saturated at low tide.

Salinity and temperature conditions were similar to those in Salthouse Lake.

The fauna was investigated by a single traverse passing through the steep edge of the bank, and for a short distance across the top. A single collection from $\frac{1}{4} \mathrm{~m} .{ }^{2}$ was made at each station.

Table VIII. Fauna of Bull Hill Bank

Clean sand at all stations. Numbers per $\frac{1}{4} \mathrm{~m}_{.}{ }^{2} ; j$, young individuals; ' - ' stations are on top, and ' + ' stations down the slope of the bank.

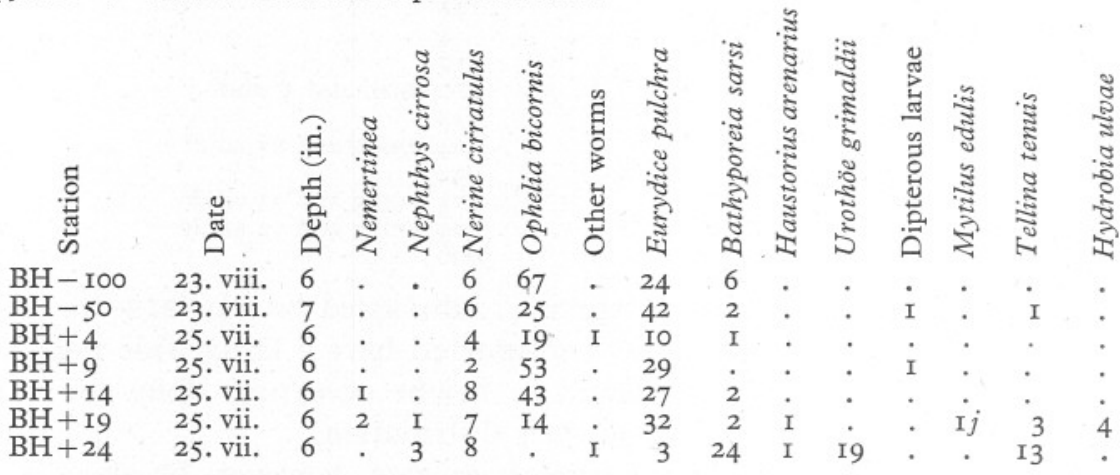

The fauna (Table VIII and Fig. In) was very poor, this being perhaps due to:

(i) Strong currents, which prevent the establishment of an epifauna.

(ii) The coarse and loose texture of the soil. Watkin (1942) found that coarser grades of sand usually supported a poorer fauna than was found in finer grades.

(iii) Drainage. This would seem to be an important factor in restricting typically intertidal species to low-water mark.

On top of the bank typical species were (Station $\mathrm{BH}-\mathrm{IO0})$ :

$\begin{array}{lccc} & \text { Per m. } .^{2} & & \text { Per m. } \\ \text { Nerine cirratulus } & 24 & \text { Eurydice pulchra } & 96 \\ \text { Ophelia bicornis } & 268 & \text { Bathyporeia sarsi } & 25\end{array}$




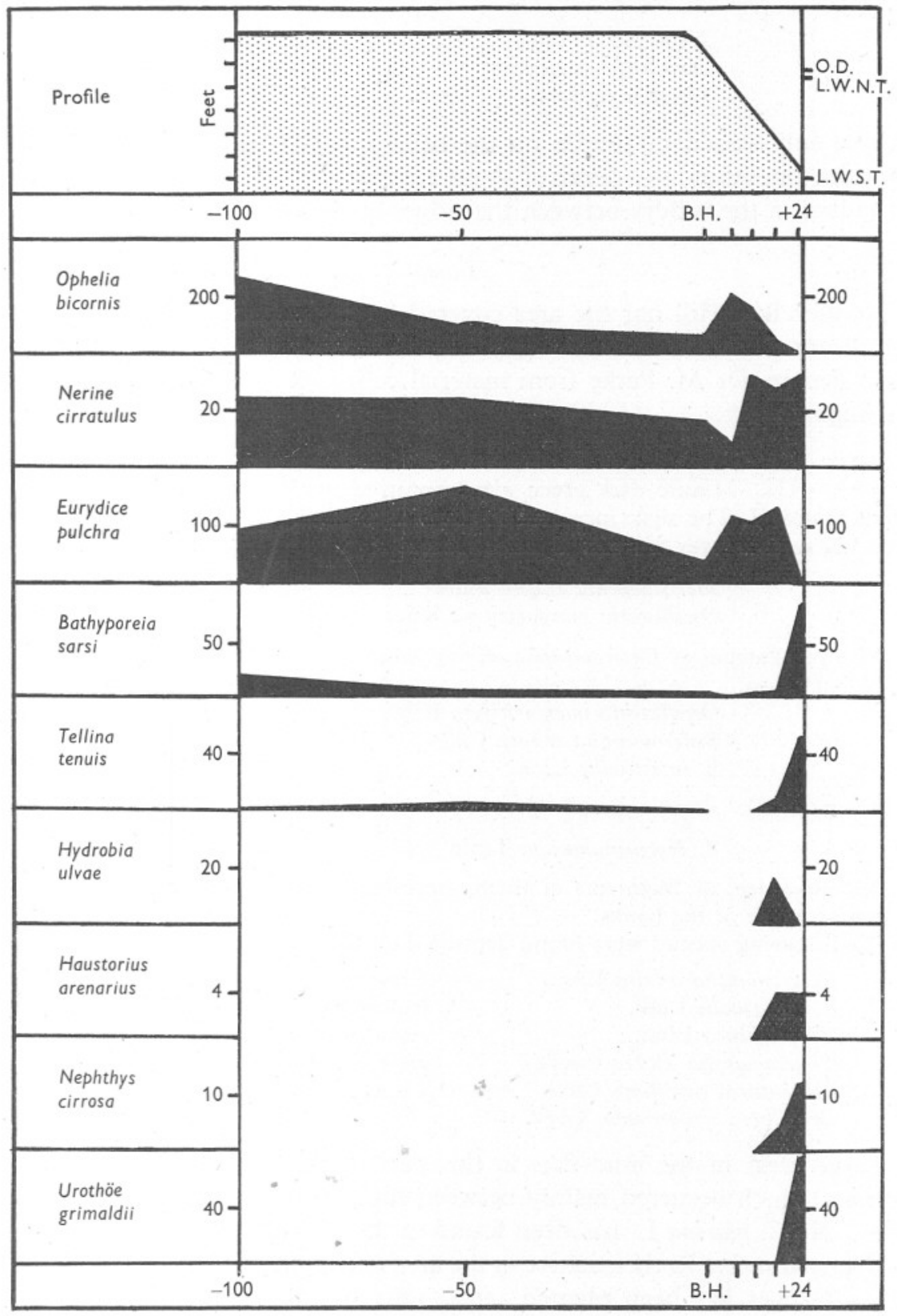

Fig. IO. Profile and fauna on Bull Hill Bank. Note that many typically intertidal species are here restricted to low-water mark. Numbers per m. ${ }^{2}$ 
At low-water mark Ophelia was absent, but certain other species appeared:

$\begin{array}{ll}\text { Nephthys cirrosa } & \text { Tellina tenuis } \\ \text { Haustorius arenarius } & \text { Hydrobia ulvae } \\ \text { Urothöe grimaldii } & \end{array}$

The only abundant species on the bank was Ophelia, which occurred all over the top, buried to a depth of about 4 in. in the sand. It seemed to be most abundant in the valleys between the ridges in the sand.

\section{Flora}

Neither Bull Hill nor the area covered by the intertidal traverse had any significant growth of surface algae. The following species have kindly been identified by Dr M. Parke from material collected on the main traverse on 29 August 1947:

I- I00. Algae absent.

I-78 $\rightarrow$ III. Minute dark green algae occurred, with a maximum abundance at about Station I. The algae increased in abundance during the summer and tended to bind the surface layer of sand. Species recorded:

\section{Merismopedia glauca Kütz \\ Oscillatoria margaritifera Kütz}

III + I5. Patches of Enteromorpha crinita J.Ag.

$\mathrm{IV} \rightarrow \mathrm{IV}+33$.

Oscillatoria margaritifera Kütz

Enteromorpha crinita J.Ag.

E. intestinalis Link.

$\mathrm{IV}+75 \rightarrow$ VI. Zostera nana Roth

\section{Z. Hornemanniana Tutin}

Drifting algae, or fragments of them, stranded by the receding tide, add to the organic content of the banks.

The following species were found deposited on the traverse:

\section{Enteromorpha crinita J.Ag. \\ E. intestinalis Link. \\ Ulva lactuca Linn. \\ Chaetomorpha litorea Cooke \\ Lomentaria clavellosa Gaill. \\ Gracilaria confervoides Grev.}

Ceramium rubrum Ag.

Callithamnion corymbosum Lyngb.

Ectocarpus confervoides Le Jol.

Isthmoplea sphaerophoia Kjellm.

Fucus vesiculosus $\mathrm{L}$.

Large areas of the mud-flats in this part of the estuary were covered by Zostera, which occurred mainly between high- and low-water mark of neap tides. No Z. marina $\mathrm{L}$. has been found in the estuary.

Spartina stricta Roth. is native in the area north of the Warren, but $S$. Town sendii Groves has been planted. Iooo setts of the latter were planted or near the Warren in November 1935 to stabilize the mud-flats. S. Townsenc is spreading slowly along the edge of the Warren, and a careful examinati revealed small clumps along the whole of the northern side of the Inr 
Warren. In the traverse area, about 200 yards square, twenty-three plants or small clumps were found. These occurred on the sand or among the Zostera, mostly at about H.W.M.N.T.

\section{Biomass AND Sources of Food}

The 'rough weight' of the principal species at certain stations was determined by weighing preserved specimens after removal of surface moisture. The shells of lamellibranchs were removed before weighing. The species comprising the 'epifauna' were not included. Details of biomasses are in Table XII.

On sand at Station I- IOO the biomass was $4.6 \mathrm{~g} . / \mathrm{m} .^{2}$, this being by far the poorest area. On Bull Hill Bank, however, where Ophelia was abundant, a total of $36.9 \mathrm{~g} . / \mathrm{m} .^{2}$ was reached, this being almost entirely made up of these worms. At Stations II, IV and VI, the biomasses were 69.3, IOI.7 and $45.4 \mathrm{~g}$. respectively. The greatest weight at these stations was made up by only four species, Arenicola, Scrobicularia, Cardium and Ampharete. It would seem that 'soil-swallowers' such as Ophelia and Arenicola have a very efficient mode of feeding, as they outweigh all other species combined at their zone of maximum abundance. Carnivores (Nephthys, Glycera, Eurydice, etc.) are nowhere abundant, comprising about $5-10 \%$ of the total weight.

MacGinitie (I935), discussing food relations in a Californian estuary, found that carnivores comprised about $5 \%$ by weight of the total population of a mud-flat. Detritus-feeders made up the greatest weight of the population, probably on account of their longevity. MacGinitie considered that the main sources of food were Zostera, Enteromorpha, Polysiphonia and pieces of algae which floated in with the tide. Very few animals lived directly on these plants, the filter-feeders subsisting mainly on plants in various stages of decay, and on bacteria. Zostera appeared to be of use not only as a source of detritus, but also for its part in the accumulation of detritus which becomes caught around its roots. Hence it was in and near the Zostera regions that the greatest abundance and variety of life was found. At low tide plant tissue tended to become dried up and killed; dead leaves started decomposing into detritus, and meanwhile would be distributed by the action of animals and by water movements, so becoming available to all the bottom animals in the neighbourhood.

Although no attempt has been made to assess the relative roles of detritus, bacteria and plankton as the food supply of animals in the Exe Estuary, it is clear that conditions are not unlike those in the Californian estuary. The settling of drifting algae on the banks has already been referred to, and the importance of Zostera as a source of food for areas outside its habitat was emphasized by some observations made in August 1947. During the neap tides of that month some parts of the Zostera beds were left uncovered for several days during hot sunny weather. When again covered by the tide some of the leaves, which had become dry and black, became detached and floated 
away. At this time leaves of Zostera were quite abundant floating up and down the estuary with the tide, being deposited on the banks as the tide receded.

\section{Notes on Certain SPecies}

The distribution of certain estuarine species is discussed by Spooner \& Moore (1940), and of sand-living species by Watkin (1942). The following notes are intended to supplement these in the light of subsequent work and the results obtained in the present survey.

\section{Phyllodoce maculata (L.) POLYCHAETA}

Fauvel (1923) regards $P$. maculata (L.) and $P$. teres Malmgren as one and the same species, although they were recorded separately by Allen \& Todd (1902). In I901, $P$. teres was found in clean sand above Starcross, in sand west of the mouth of Salthouse Lake, and from gravel between Powderham and Starcross. A specimen doubtfully assigned to $P$. maculata was taken on the sandy ground between Starcross and Cockwood.

The specimens found in 1947 were probably of the same species as those previously taken, but identification was difficult as many of the specimens were fragmented. Phyllodoce was found on the more muddy part of the main traverse, from Stations III +67 to VI +3 . It was not found on Bull Hill.

\section{Eteone longa (Fabricius)}

In I90I Allen \& Todd found specimens identified as E. pusilla Örsted (nec Malmgren) in clean sand; and it seems likely that the 1947 specimens were of the same species as found in I90I, but there is some doubt as to their identity. Those found in 1947 had a head approaching that described by Malmgren (I865) for E. pusilla, but the anal cirri are not 'lineare-fusiformes elongati', but of the type described by Örsted (I843) as 'papillis caudalibus subglobosis'. The head does not correspond with Örsted's description, however. Fauvel (1923) does not refer to $E$. pusilla Örsted, and E. pusilla Malmgren is now $E$. lactea Claparède.

The specimens correspond most closely to Eteone longa (Fabricius), both in the shape of the head and of the anal cirri, and it is to this species that they have been provisionally assigned.

Eteone extended from sand to mud on the main traverse. Intertidally it ranged from about H.W.M.N.T. to about L.W.M.N.T., with a maximum near the upper part of its range. It was absent from Bull Hill.

\section{Nephthys hombergi Lamarck}

This species was recorded by Allen \& Todd from sand and muddy sand all over the estuary, but not in very muddy ground.

In 1947 it was collected at stations ranging from sand to mud. Its maximum 
density was at IV +33 : I04 per $\mathrm{m}^{2}$; with a silt content of $9 \cdot 4 \%$. It was less abundant, c. I2 per m. ${ }^{2}$, at IV, where the silt content was $16.6 \%$, and was absent on muddy stations with Zostera, where the silt percentage ranged from II 2 to $22 \cdot 6$. At the other end of the traverse it did not extend beyond I +30 , possibly being limited by the better drainage at this end. Intertidally it ranged throughout the tidal zone, with no distinct maximum. It was not found on Bull Hill.

This species is not confined to the shore, being common on sandy and muddy bottoms at sea. Spooner \& Moore (1940) and Alexander, Southgate \& Bassindale (I935) have found it plentiful towards the mouth of the estuaries of the Tamar and Tees respectively. On the Tamar its normal density was between I00 and 300 per m. ${ }^{2}$, rather higher than that met with on the Exe. Brady (1943), however, found the maximum density of this species at Black Middens on the Northumberland coast to be only 60 per m. ${ }^{2}$

\section{Nephthys cirrosa Ehlers}

Found by Allen \& Todd only in fine, clean sand, where it was quite plentiful.

In 1947 this species was found in wet sand at stations between II and $\mathrm{III}+33$, the silt content ranging from $\mathrm{I} \cdot 35$ to $6 \cdot 9 \%$. Intertidally, it occurred at most stations, with its greatest density, 32 per $\mathrm{m} .{ }^{2}$, near low-water mark. On Bull Hill it was restricted to two stations near low-water mark. The intertidal range of this species thus seems to be dependent on drainage conditions in the sand.

There are few other records of this species. In the Plymouth Marine Fauna (Marine Biological Assoc., I93I) it is recorded from sand between tide-marks on Drakes Island and the Yealm Estuary. Bassindale (1938) found single specimens in sand near the mouth of the Mersey Estuary. Rees (1939) found it on a number of traverses on sandy shores in North Donegal; the species extended up the beach to half-tide mark, maximum numbers occurring at low-water mark.

\section{Scoloplos armiger (O. F. Müller)}

In I90I this species was found in sand or muddy sand within the estuary, but not on the Pole Sands. In the 1947 survey it was found on soils ranging from 0.7 to $16.6 \%$ silt, but was absent at the muddiest stations. Its highest density was in muddy sand at III +33: I08 per $\mathrm{m}^{2}{ }^{2}$, the silt content being $6.9 \%$. It did not occur on the well-drained sand, and was absent from Bull Hill. Intertidally it showed a maximum just below H.W.M.N.T.

The distribution of Scoloplos on the main traverse resembles that of Macoma and Nephthys hombergi, being typical of species with an optimum density in muddy sand, and being intolerant of 'pure' mud. It is recorded from muddy sand in a number of areas, but not from clean, sandy beaches, and it is usually less abundant in mud. Spooner \& Moore (I940) found it in moderate numbers, 
up to I 52 per m. ${ }^{2}$, on St John's Lake, where it seemed to be restricted to the upper tidal levels in the Zostera zone.

Brady (I943) found Scoloplos at Budle Bay on the Northumberland coast. It was widely distributed in slightly muddy sand, its density seeming to be inversely related to that of Macoma balthica. The author considered that the two species were in competition for detritus as food, but that since Macoma also fed on suspended detrital and planktonic matter, it tended to become the dominant species. Thus Scoloplos could only become really abundant where Macoma was for some reason scarce.

The density of Macoma on the Salthouse Lake traverse was nowhere great, so that competition for food between the two species was probably not very intense. On the whole, Macoma and Scoloplos show similar distribution and densities, so failing to agree with Brady's observations.

\section{Nerine foliosa (Audouin \& Edwards)}

This species was recorded as $N$. coniocephala Johnston by Allen \& Todd, several specimens being obtained in sand west of the mouth of Salthouse Lake and in the hard clayey mud to the north of it.

In 1947 small numbers were found on clean sand at Stations I-40 and I-3 A, also among gravel above H.W.M.N.T. at B-3. None was found on Bull Hill.

There are few records of this species: Percival (1929) records it from the River Tamar, in mud; in the Plymouth Marine Fauna it is also recorded from Wembury, Drakes Island, east side of the Sound, Kingsand Beach, and the River Yealm sand bank. Brady (1943) found it in Budle Bay, a few occurring at about low-water mark in firm clayey sand.

\section{Nerine cirratulus (Della Chiaje)}

In I90I specimens were found on Bull Hill Bank and Cocklesand.

In 1947 it was found in small numbers on the main traverse chiefly in clean, fairly well-drained sand near Station I. It did not occur in company with Ophelia on this traverse. On Bull Hill, however, it was more abundant, occurring at all stations, and was therefore occurring with Ophelia.

The distribution of this species is discussed by Watkin (1942), who finds it to have a wide intertidal range, with maximum densities about half-tide mark. Pirrie, Bruce \& Moore (1932) describe a similar zonation on the sandy beach at Port Erin. It is recorded from muddy sand at Salcombe by Allen \& Todd (1900), and in the Mersey Estuary by Bassindale (1938).

\section{Pygospio elegans Claparède}

Allen \& Todd record this species in clean hard sand inside the estuary, but not on the Pole Sands.

Pygospio was found at nearly all stations on the main traverse, the maximum 
The vertical distribution of species at Station $\mathrm{I}+30$ is shown in Table VI; it will be seen that practically all species occur in the top 4 in., notable exceptions being Arenicola marina and Urothöe grimaldii.

The close proximity of the various types of ground may also affect the distribution of certain species. Individuals may stray from their typical habitat (perhaps as a result of 'population pressure') so that in time a species will come to colonize all suitable grounds. This spreading tendency presumably operates continually and will result in a fringing zone where individuals may occur on quite atypical grounds. The extent of this zone will vary with the migratory ability of the species and the degree of unsuitability of the ground to be traversed. The outstanding example here was Hydrobia ulvae, normally inhabiting the mud, particularly the Zostera beds, but which is continually endeavouring to extend its range so that specimens occur even on the sandy grounds. They would not occur there but for the contiguity of their normal habitat.

The fauna of the main traverse may be arbitrarily divided into a number of zones:

(I) Fauna of clean loose sand. Stations I-IOO and I-40. The silt content was less than $\mathrm{I} \%$ and the grade of sand was coarser than at other stations on this traverse. The sand was very well drained, there being no black-layer near the surface.

Typical species were (Station $\mathrm{I}-40$ ):

$\begin{array}{lclc} & \text { Per m. }{ }^{2} & & \text { Per m. }{ }^{2} \\ \text { Ophelia bicornis } & \text { I2 } & \text { Bathyporeia pilosa } & \text { I448 } \\ \text { Nerine foliosa } & \text { I2 } & \text { Corophim arenarium } & \text { I6 } \\ \text { Pygospio elegans } & \text { A few } & \text { Hydrobia ulvae } & 32 \\ \text { Eurydice pulchra } & \text { 6I2 } & & \end{array}$

(2) Fauna of firm moist sand. Stations I-III. The sand was rather finer than at the previous stations. The silt content rose from $0.05 \%$ to a maximum of $2 \cdot 2 \%$ at II +67 . The bank sloped down gently, so that while Stations I to I +67 were fairly well drained, the subsequent stations had standing water on the surface. A black layer usually occurred within a few inches of the surface.

Typical species were (Station II +33):

$\begin{array}{lclc} & \text { Per m. }{ }^{2} & & \text { Per m. } .^{2} \\ \text { Nephthys hombergi } & 24 & \text { Urothöe grimaldii } & 268 \\ \text { N. cirrosa } & 8 & \text { Corophium arenarium } & 280 \\ \text { Scoloplos armiger } & \text { I2 } & \text { Tellina tenuis } & 76 \\ \text { Pygospio elegans } & \text { Common } & \text { Macoma balthica } & 8 \\ \text { Arenicola marina } & 44 & \text { Cardium edule } & 8 \text { young } \\ \text { Bathyporeia sarsi } & \mathrm{I} 64 & \text { Hydrobia ulvae } & 448\end{array}$

Ophelia bicornis and Nerine foliosa were no longer present, and Eurydice was much less frequent. Bathyporeia pilosa had been replaced by B. sarsi, probably due to the fall in height. According to Watkin (1938) B. pilosa is restricted to a narrow zone at about H.W.M.N.T., whereas $B$. sarsi has a wider range extending down to below low-water mark. A number of species appeared at 
about Station I and extended almost the length of the traverse; e.g. Nephthys hombergi, Scoloplos armiger, Scrobicularia plana and Cardium edule. But Bathyporeia sarsi, Tellina, Urothöe and Nerine cirratulus were restricted to the clean sand of this zone.

(3) Muddy sand. Stations III +33 to IV +80 . This was a transitional zone from sand to mud. At Station III +33 the silt content was $6.9 \%$, and a maximum of $16.6 \%$ silt occurred at Station IV. The other grades of soil were in very similar proportions to that found elsewhere in the traverse. The rise in silt content seems to be the cause of the absence of Bathyporeia, Tellina, Urothöe and Nerine; but the species extending into this zone usually show a higher density than on the clean sand.

Typical species were (Station IV +3):

$\begin{array}{lclc} & \text { Per m. }{ }^{2} & & \text { Per m. }{ }^{2} \\ \text { Nephthys hombergi } & \text { I6 } & \text { Corophium arenarium } & 44 \\ \text { Glycera convoluta } & 20 & \text { Macoma balthica } & 4 \\ \text { Pygospio elegans } & \text { Present } & \text { Scrobicularia plana } & \text { I80 young and 40 adult } \\ \text { Arenicola marina } & \text { I2 } & \text { Cardium edule } & 8 \text { young and 28 adult } \\ \text { Ampharete grubei } & 3552 & \text { Hydrobia ulvae } & 620 \\ \text { Melinna palmata } & 8 & & \end{array}$

Large numbers of Ampharete occur; this species being most abundant where the silt content is high. Pygospio occurred in small numbers, and thus inhabits a wide range of soils.

(4) Mud with Zostera. Stations V and VI. The soil contained about IO- $20 \%$ of silt, and was of a rather clayey consistency. When walking over it, one's feet sunk in only a few inches. Holes dug in the mud persisted for months after digging. The surface of the mud was covered by a dense growth of $Z$. hornemanniana Tutin and $Z$. nana Roth, which provided a refuge for numerous small Carcinus maenas and Hydrobia ulvae. Small specimens of Arenicola marina were abundant. The burrowing fauna was, if anything, a little less dense than on the muddy sand. Macoma, Scoloplos and Nephthys hombergi were absent.

Typical species were (Station $\mathrm{V}+3$ ):

Per m. ${ }^{2}$

Arenicola marina

Ampharete grubei

Carcinus maenas

Scrobicularia plana

Conditions

88 small and 4 adult
3984
160
48 young and 60 adult

Per m. ${ }^{2}$

Cardium edule

Littorina rudis

L. littorea

$\begin{array}{lr}\text { L. littorea } & 84 \\ \text { Hydrobia ulvae } & 13,280\end{array}$

I 3,280

284 young and 4 adult

This was at right angles to the main traverse, crossing it at Station II, which is identical with Station E. Stations were at Ioo ft. intervals and were designated A, B, C . . H. 'A' was near high-water mark, and ' $\mathrm{H}$ ' at lowwater mark. Stations A, B and C were on gravel, with some admixture of sand. The fauna at these stations was imperfectly sampled owing to difficulties in 
sieving. From $\mathrm{C}+\mathrm{I} 2$ to $\mathrm{H}$ the soil was fairly clean moist sand, overlying the bed of clay. Grade analyses showed a silt content of under I $\%$ for stations from D downwards (Table VII).

Table VII. Soll Grades on the Intertidal Traverse, Expressed as Percentages by Weight

\begin{tabular}{|c|c|c|c|c|c|c|}
\hline Station & $>2 \mathrm{~mm}$ & $2-0.5 \mathrm{~mm}$. & $0.5-0.256 \mathrm{~mm}$ & $0.256-0.22 \mathrm{~mm}$. & $0.22-0.02 \mathrm{~mm}$ & $\begin{array}{l}\text { Silt and } \\
\text { clay }\end{array}$ \\
\hline A & Many stones & $24 \cdot 3$ & $44 \cdot 5$ & I9. 6 & II $\cdot I$ & 0.5 \\
\hline $\mathrm{B}$ & Few stones & $5 \cdot 7$ & 38.7 . & $29 \cdot 7$ & 24.0 & $2 \cdot 0$ \\
\hline C & Few stones & 2.5 & 9.3 & 10.0 & $73 \cdot 8$ & 4.4 \\
\hline $\mathrm{D}$ & Nil & $I \cdot 6$ & 19.5 & $25 \cdot 0$ & 53.0 & $I \cdot 0$ \\
\hline $\mathrm{E}$ & Nil & $I \cdot I$ & 13.9 & $2 I \cdot 2$ & $62 \cdot 2$ & $I \cdot 6$ \\
\hline $\mathrm{F}$ & $\mathrm{Nil}$ & 0.8 & I3.9 & $26 \cdot I$ & $58 \cdot 7$ & 0.6 \\
\hline G & Nil & 0.4 & $8 \cdot 4$ & $28 \cdot 9$ & $6 r \cdot 3$ & 0.9 \\
\hline $\mathrm{H}$ & Nil & 0.2 & $4 \cdot 5$ & 16.5 & $77 \cdot 7$ & $I \cdot 0$ \\
\hline
\end{tabular}

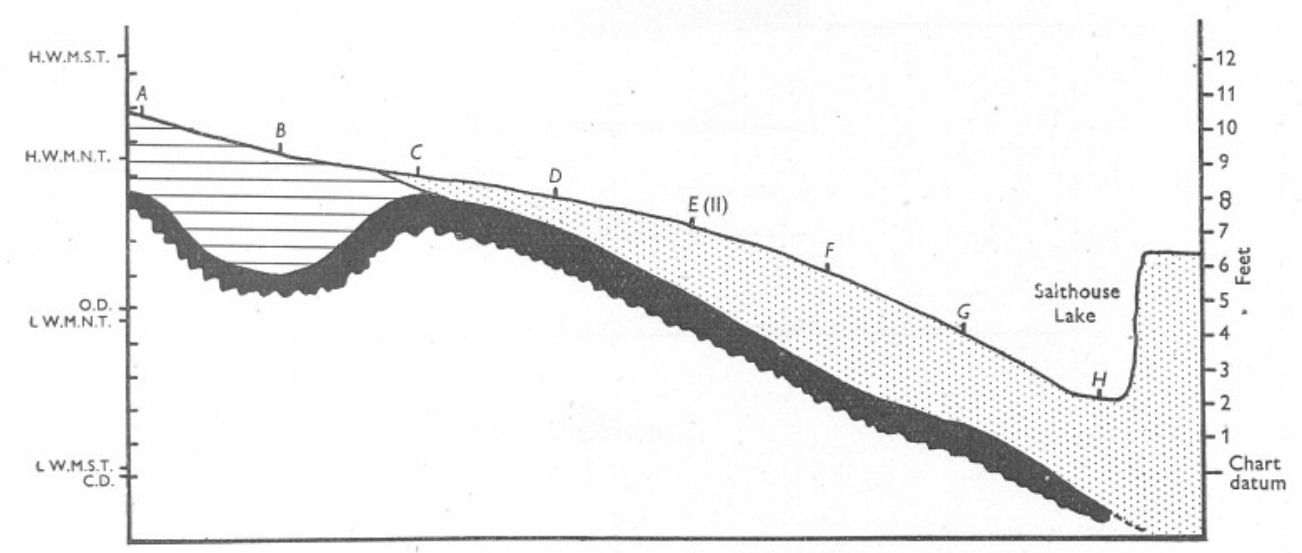

Fig. 8. Profile of the intertidal traverse. Vertical scale greatly exaggerated. Interval between stations is $100 \mathrm{ft}$. The white area is below the depth investigated.
Sand.
ए Gravel.
질 Clay.

The profile of the traverse is shown in Fig. 8. The bank sloped down to Salthouse Lake, so that there was little scouring of the banks near low water. This is in contrast to banks adjacent to the main channel which are exposed to a considerable tidal stream. The water-table was at or near the surface at all stations, and a black-layer was usually present at a depth of a few inches. Other conditions were similar to those to which the main traverse was exposed.

$\mathrm{pH}$ was determined electrically from samples taken at low tide on 2I August I947:

$\begin{array}{llll} & \mathrm{pH} & & \mathrm{pH} \\ \mathrm{A} & 7 \cdot 9 & \mathrm{E} & 7 \cdot 5 \\ \mathrm{~B} & 7 \cdot 9 & \mathrm{~F} & 7 \cdot 8 \\ \mathrm{C} & 7 \cdot 7 & \mathrm{G} & 7 \cdot 8 \\ \mathrm{D} & 7 \cdot 8 & \mathrm{H} & 8.0\end{array}$




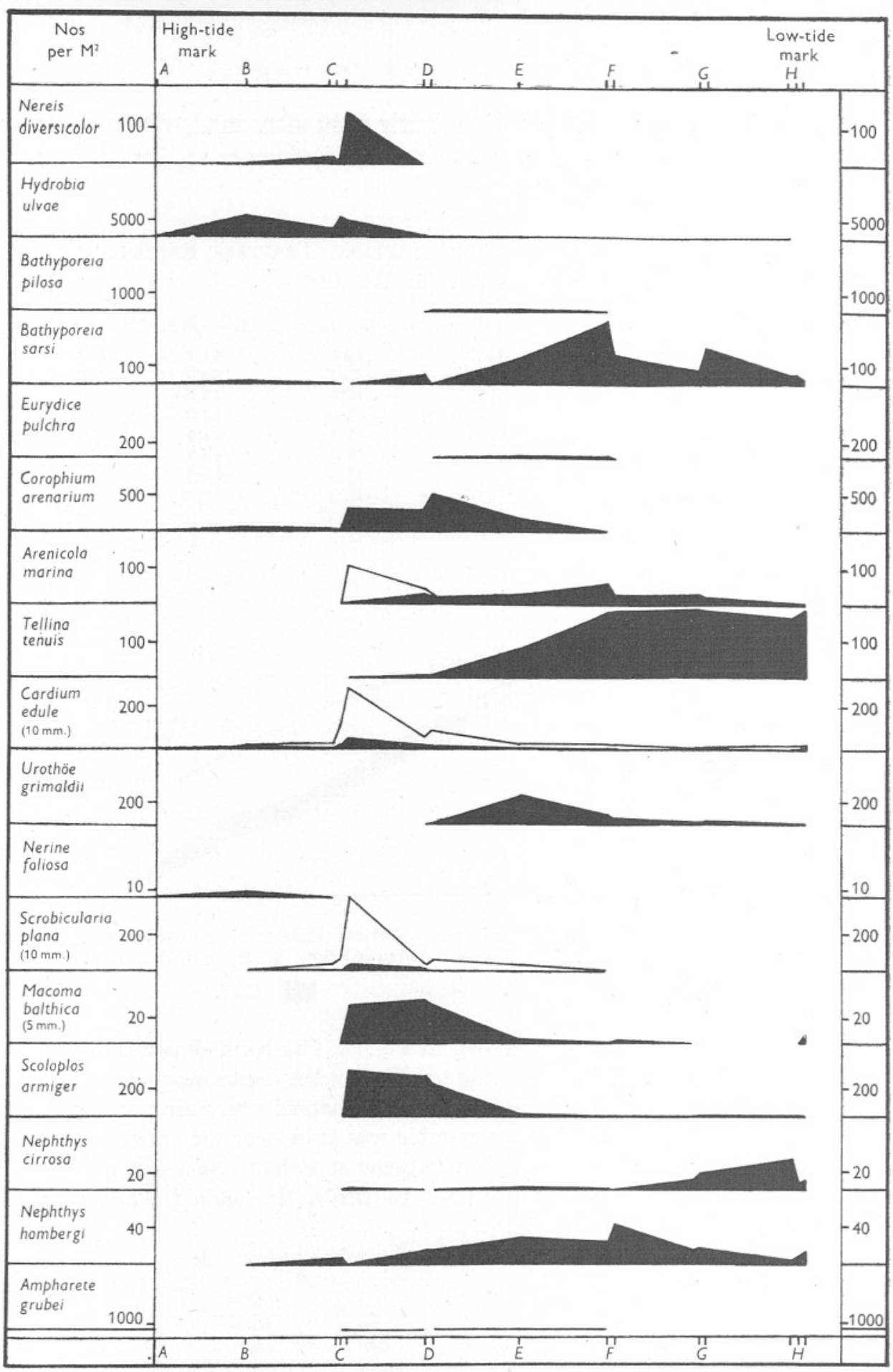

Fig. 9. Distribution of certain species on the intertidal traverse. For explanations see Fig. 6. Station ' $E$ ' is the average of numbers from Stations II -3 and II +3 . 


\section{Fauna}

The results obtained from quantitative sampling are shown in Table $\mathrm{V}$ and in Fig. 9. Only one collection was made at Stations A and B; and additional collections were made at $\mathrm{C}+\mathrm{I}_{5}$ and $\mathrm{H}+\mathrm{I}_{5}$, the latter being in the bed of Salthouse Lake. No other intermediate stations were worked.

The stations are too few to give a detailed picture of the distribution of the fauna, the object of these collections being to determine the intertidal distribution of species occurring in the main traverse. At Stations A, B and C the fauna was poor, especially in burrowing species. At $\mathrm{C}-3$ typical species were:

Nereis diversicolor Nephthys hombergi Corophium arenarium Larval Diptera Scrobicularia plana

\section{Per $\mathrm{m}^{2}$}

20
8
24
44
I6 young

Per . $^{2}$

Cardium edule Littorina rudis L. littorea Hydrobia ulvae $\quad 2468$

At Station C + I5, off the edge of the gravel, many species were abundant. The silt content was probably about $3 \%$, but was not determined. Small individuals of Arenicola, Cardium and Scrobicularia were very abundant. Typical species included:

Nereis diversicolor
Nephthys hombergi
Scoloplos armiger
Arenicola marina
Corophium arenarium
Mytilus edulis
Macoma balthica
Scrobicularia plana
Cardium edule
Hydrobia ulvae

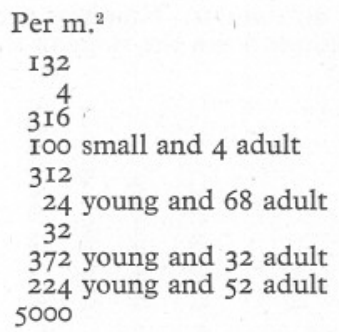

The intertidal distribution of species is discussed on pp. 218-28. It is apparent that most of the species encountered have a fairly wide intertidal range, so that the small differences in height occurring along the main traverse would have little effect on their distribution.

The distribution of the following species may, however, be affected by small changes in height: Nereis diversicolor occurred at about H.W.M.N.T., and was consequently scarce on the main traverse, which was at a slightly lower level. Bathyporeia pilosa, Eurydice pulchra and Nerine foliosa occurred only at about half-tide mark, and this may account for their occurrence only at the higher stations on the main traverse. Drainage may also be an important factor in determining their distribution.

\section{Bull Hill Bank}

This was a bank of clean sand in the middle of the estuary near Dawlish Warren. The bank was scoured by strong currents, and to a lesser extent by waves; the surface of the sand being consequently furrowed, and the edge 
facing the main channel sloped away steeply. The top was at about half-tide mark, and was fairly level.

The sand was rather coarser than that from Salthouse Lake. A sample from the top of the bank (from Station $\mathrm{BH}+\mathrm{IO0}$ ) giving on analysis:

$\begin{array}{cccc}(\mathrm{mm} .) & (\%) & (\mathrm{mm} .) & (\%) \\ >2 & - & 0.256-0.22 & 30 . \mathrm{I} \\ 2-0.5 & 5 . \mathrm{I} & 0.22-0.02 & 10.3 \\ 0.5-0.256 & 54.0 & \text { Silt and clay } & 0.5\end{array}$

Independent analyses of the sand from Bull Hill Bank and Salthouse Lake are given by Wilson (1948).

There was no black-layer in the soil, which was very well drained, except near low-water mark, where it remained saturated at low tide.

Salinity and temperature conditions were similar to those in Salthouse Lake.

The fauna was investigated by a single traverse passing through the steep edge of the bank, and for a short distance across the top. A single collection from $\frac{1}{4} \mathrm{~m} .{ }^{2}$ was made at each station.

Table VIII. Fauna of Bull Hill Bank

Clean sand at all stations. Numbers per $\frac{1}{4} \mathrm{~m}_{.}{ }^{2} ; j$, young individuals; ' - ' stations are on top, and ' + ' stations down the slope of the bank.

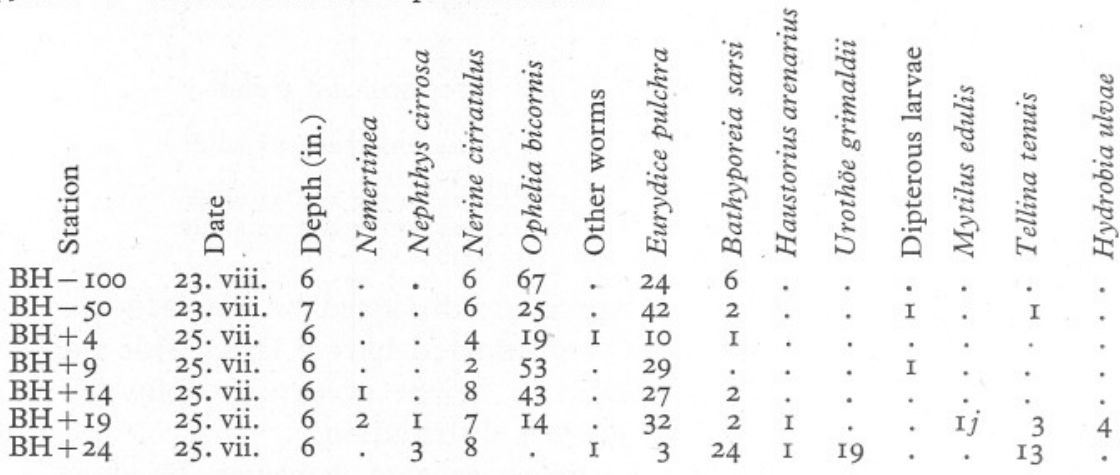

The fauna (Table VIII and Fig. In) was very poor, this being perhaps due to:

(i) Strong currents, which prevent the establishment of an epifauna.

(ii) The coarse and loose texture of the soil. Watkin (1942) found that coarser grades of sand usually supported a poorer fauna than was found in finer grades.

(iii) Drainage. This would seem to be an important factor in restricting typically intertidal species to low-water mark.

On top of the bank typical species were (Station $\mathrm{BH}-\mathrm{IO0})$ :

$\begin{array}{lccc} & \text { Per m. } .^{2} & & \text { Per m. } \\ \text { Nerine cirratulus } & 24 & \text { Eurydice pulchra } & 96 \\ \text { Ophelia bicornis } & 268 & \text { Bathyporeia sarsi } & 25\end{array}$




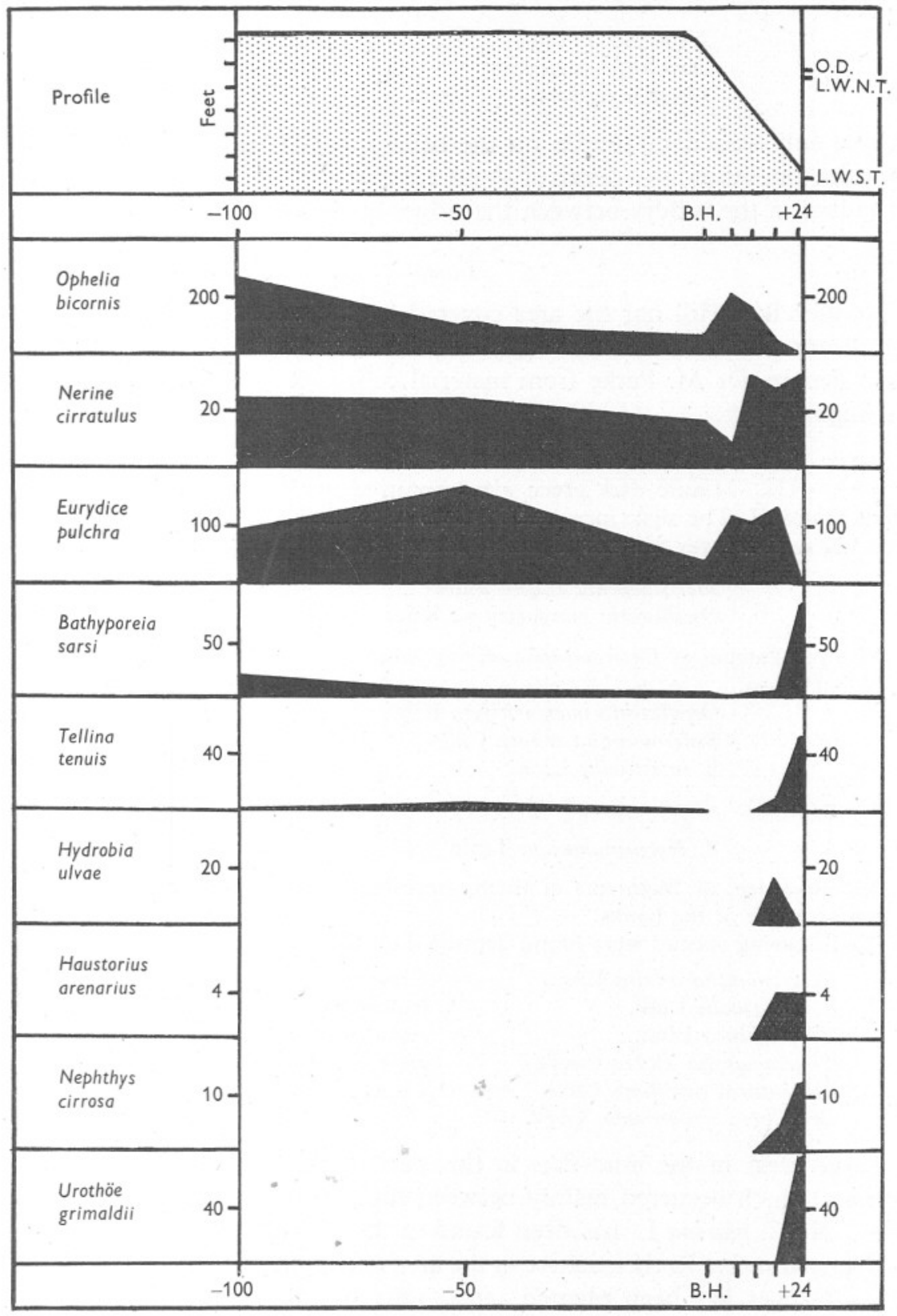

Fig. IO. Profile and fauna on Bull Hill Bank. Note that many typically intertidal species are here restricted to low-water mark. Numbers per m. ${ }^{2}$ 
At low-water mark Ophelia was absent, but certain other species appeared:

$\begin{array}{ll}\text { Nephthys cirrosa } & \text { Tellina tenuis } \\ \text { Haustorius arenarius } & \text { Hydrobia ulvae } \\ \text { Urothöe grimaldii } & \end{array}$

The only abundant species on the bank was Ophelia, which occurred all over the top, buried to a depth of about 4 in. in the sand. It seemed to be most abundant in the valleys between the ridges in the sand.

\section{Flora}

Neither Bull Hill nor the area covered by the intertidal traverse had any significant growth of surface algae. The following species have kindly been identified by Dr M. Parke from material collected on the main traverse on 29 August 1947:

I- I00. Algae absent.

I-78 $\rightarrow$ III. Minute dark green algae occurred, with a maximum abundance at about Station I. The algae increased in abundance during the summer and tended to bind the surface layer of sand. Species recorded:

\section{Merismopedia glauca Kütz \\ Oscillatoria margaritifera Kütz}

III + I5. Patches of Enteromorpha crinita J.Ag.

$\mathrm{IV} \rightarrow \mathrm{IV}+33$.

Oscillatoria margaritifera Kütz

Enteromorpha crinita J.Ag.

E. intestinalis Link.

$\mathrm{IV}+75 \rightarrow$ VI. Zostera nana Roth

\section{Z. Hornemanniana Tutin}

Drifting algae, or fragments of them, stranded by the receding tide, add to the organic content of the banks.

The following species were found deposited on the traverse:

\section{Enteromorpha crinita J.Ag. \\ E. intestinalis Link. \\ Ulva lactuca Linn. \\ Chaetomorpha litorea Cooke \\ Lomentaria clavellosa Gaill. \\ Gracilaria confervoides Grev.}

Ceramium rubrum Ag.

Callithamnion corymbosum Lyngb.

Ectocarpus confervoides Le Jol.

Isthmoplea sphaerophoia Kjellm.

Fucus vesiculosus $\mathrm{L}$.

Large areas of the mud-flats in this part of the estuary were covered by Zostera, which occurred mainly between high- and low-water mark of neap tides. No Z. marina $\mathrm{L}$. has been found in the estuary.

Spartina stricta Roth. is native in the area north of the Warren, but $S$. Town sendii Groves has been planted. Iooo setts of the latter were planted or near the Warren in November 1935 to stabilize the mud-flats. S. Townsenc is spreading slowly along the edge of the Warren, and a careful examinati revealed small clumps along the whole of the northern side of the Inr 
Warren. In the traverse area, about 200 yards square, twenty-three plants or small clumps were found. These occurred on the sand or among the Zostera, mostly at about H.W.M.N.T.

\section{Biomass AND Sources of Food}

The 'rough weight' of the principal species at certain stations was determined by weighing preserved specimens after removal of surface moisture. The shells of lamellibranchs were removed before weighing. The species comprising the 'epifauna' were not included. Details of biomasses are in Table XII.

On sand at Station I- IOO the biomass was $4.6 \mathrm{~g} . / \mathrm{m} .^{2}$, this being by far the poorest area. On Bull Hill Bank, however, where Ophelia was abundant, a total of $36.9 \mathrm{~g} . / \mathrm{m} .^{2}$ was reached, this being almost entirely made up of these worms. At Stations II, IV and VI, the biomasses were 69.3, IOI.7 and $45.4 \mathrm{~g}$. respectively. The greatest weight at these stations was made up by only four species, Arenicola, Scrobicularia, Cardium and Ampharete. It would seem that 'soil-swallowers' such as Ophelia and Arenicola have a very efficient mode of feeding, as they outweigh all other species combined at their zone of maximum abundance. Carnivores (Nephthys, Glycera, Eurydice, etc.) are nowhere abundant, comprising about $5-10 \%$ of the total weight.

MacGinitie (I935), discussing food relations in a Californian estuary, found that carnivores comprised about $5 \%$ by weight of the total population of a mud-flat. Detritus-feeders made up the greatest weight of the population, probably on account of their longevity. MacGinitie considered that the main sources of food were Zostera, Enteromorpha, Polysiphonia and pieces of algae which floated in with the tide. Very few animals lived directly on these plants, the filter-feeders subsisting mainly on plants in various stages of decay, and on bacteria. Zostera appeared to be of use not only as a source of detritus, but also for its part in the accumulation of detritus which becomes caught around its roots. Hence it was in and near the Zostera regions that the greatest abundance and variety of life was found. At low tide plant tissue tended to become dried up and killed; dead leaves started decomposing into detritus, and meanwhile would be distributed by the action of animals and by water movements, so becoming available to all the bottom animals in the neighbourhood.

Although no attempt has been made to assess the relative roles of detritus, bacteria and plankton as the food supply of animals in the Exe Estuary, it is clear that conditions are not unlike those in the Californian estuary. The settling of drifting algae on the banks has already been referred to, and the importance of Zostera as a source of food for areas outside its habitat was emphasized by some observations made in August 1947. During the neap tides of that month some parts of the Zostera beds were left uncovered for several days during hot sunny weather. When again covered by the tide some of the leaves, which had become dry and black, became detached and floated 
away. At this time leaves of Zostera were quite abundant floating up and down the estuary with the tide, being deposited on the banks as the tide receded.

\section{Notes on Certain SPecies}

The distribution of certain estuarine species is discussed by Spooner \& Moore (1940), and of sand-living species by Watkin (1942). The following notes are intended to supplement these in the light of subsequent work and the results obtained in the present survey.

\section{Phyllodoce maculata (L.) POLYCHAETA}

Fauvel (1923) regards $P$. maculata (L.) and $P$. teres Malmgren as one and the same species, although they were recorded separately by Allen \& Todd (1902). In I901, $P$. teres was found in clean sand above Starcross, in sand west of the mouth of Salthouse Lake, and from gravel between Powderham and Starcross. A specimen doubtfully assigned to $P$. maculata was taken on the sandy ground between Starcross and Cockwood.

The specimens found in 1947 were probably of the same species as those previously taken, but identification was difficult as many of the specimens were fragmented. Phyllodoce was found on the more muddy part of the main traverse, from Stations III +67 to VI +3 . It was not found on Bull Hill.

\section{Eteone longa (Fabricius)}

In I90I Allen \& Todd found specimens identified as E. pusilla Örsted (nec Malmgren) in clean sand; and it seems likely that the 1947 specimens were of the same species as found in I90I, but there is some doubt as to their identity. Those found in 1947 had a head approaching that described by Malmgren (I865) for E. pusilla, but the anal cirri are not 'lineare-fusiformes elongati', but of the type described by Örsted (I843) as 'papillis caudalibus subglobosis'. The head does not correspond with Örsted's description, however. Fauvel (1923) does not refer to $E$. pusilla Örsted, and E. pusilla Malmgren is now $E$. lactea Claparède.

The specimens correspond most closely to Eteone longa (Fabricius), both in the shape of the head and of the anal cirri, and it is to this species that they have been provisionally assigned.

Eteone extended from sand to mud on the main traverse. Intertidally it ranged from about H.W.M.N.T. to about L.W.M.N.T., with a maximum near the upper part of its range. It was absent from Bull Hill.

\section{Nephthys hombergi Lamarck}

This species was recorded by Allen \& Todd from sand and muddy sand all over the estuary, but not in very muddy ground.

In 1947 it was collected at stations ranging from sand to mud. Its maximum 
density was at IV +33 : I04 per $\mathrm{m}^{2}$; with a silt content of $9 \cdot 4 \%$. It was less abundant, c. I2 per m. ${ }^{2}$, at IV, where the silt content was $16.6 \%$, and was absent on muddy stations with Zostera, where the silt percentage ranged from II 2 to $22 \cdot 6$. At the other end of the traverse it did not extend beyond I +30 , possibly being limited by the better drainage at this end. Intertidally it ranged throughout the tidal zone, with no distinct maximum. It was not found on Bull Hill.

This species is not confined to the shore, being common on sandy and muddy bottoms at sea. Spooner \& Moore (1940) and Alexander, Southgate \& Bassindale (I935) have found it plentiful towards the mouth of the estuaries of the Tamar and Tees respectively. On the Tamar its normal density was between I00 and 300 per m. ${ }^{2}$, rather higher than that met with on the Exe. Brady (1943), however, found the maximum density of this species at Black Middens on the Northumberland coast to be only 60 per m. ${ }^{2}$

\section{Nephthys cirrosa Ehlers}

Found by Allen \& Todd only in fine, clean sand, where it was quite plentiful.

In 1947 this species was found in wet sand at stations between II and $\mathrm{III}+33$, the silt content ranging from $\mathrm{I} \cdot 35$ to $6 \cdot 9 \%$. Intertidally, it occurred at most stations, with its greatest density, 32 per $\mathrm{m} .{ }^{2}$, near low-water mark. On Bull Hill it was restricted to two stations near low-water mark. The intertidal range of this species thus seems to be dependent on drainage conditions in the sand.

There are few other records of this species. In the Plymouth Marine Fauna (Marine Biological Assoc., I93I) it is recorded from sand between tide-marks on Drakes Island and the Yealm Estuary. Bassindale (1938) found single specimens in sand near the mouth of the Mersey Estuary. Rees (1939) found it on a number of traverses on sandy shores in North Donegal; the species extended up the beach to half-tide mark, maximum numbers occurring at low-water mark.

\section{Scoloplos armiger (O. F. Müller)}

In I90I this species was found in sand or muddy sand within the estuary, but not on the Pole Sands. In the 1947 survey it was found on soils ranging from 0.7 to $16.6 \%$ silt, but was absent at the muddiest stations. Its highest density was in muddy sand at III +33: I08 per $\mathrm{m}^{2}{ }^{2}$, the silt content being $6.9 \%$. It did not occur on the well-drained sand, and was absent from Bull Hill. Intertidally it showed a maximum just below H.W.M.N.T.

The distribution of Scoloplos on the main traverse resembles that of Macoma and Nephthys hombergi, being typical of species with an optimum density in muddy sand, and being intolerant of 'pure' mud. It is recorded from muddy sand in a number of areas, but not from clean, sandy beaches, and it is usually less abundant in mud. Spooner \& Moore (I940) found it in moderate numbers, 
up to I 52 per m. ${ }^{2}$, on St John's Lake, where it seemed to be restricted to the upper tidal levels in the Zostera zone.

Brady (I943) found Scoloplos at Budle Bay on the Northumberland coast. It was widely distributed in slightly muddy sand, its density seeming to be inversely related to that of Macoma balthica. The author considered that the two species were in competition for detritus as food, but that since Macoma also fed on suspended detrital and planktonic matter, it tended to become the dominant species. Thus Scoloplos could only become really abundant where Macoma was for some reason scarce.

The density of Macoma on the Salthouse Lake traverse was nowhere great, so that competition for food between the two species was probably not very intense. On the whole, Macoma and Scoloplos show similar distribution and densities, so failing to agree with Brady's observations.

\section{Nerine foliosa (Audouin \& Edwards)}

This species was recorded as $N$. coniocephala Johnston by Allen \& Todd, several specimens being obtained in sand west of the mouth of Salthouse Lake and in the hard clayey mud to the north of it.

In 1947 small numbers were found on clean sand at Stations I-40 and I-3 A, also among gravel above H.W.M.N.T. at B-3. None was found on Bull Hill.

There are few records of this species: Percival (1929) records it from the River Tamar, in mud; in the Plymouth Marine Fauna it is also recorded from Wembury, Drakes Island, east side of the Sound, Kingsand Beach, and the River Yealm sand bank. Brady (1943) found it in Budle Bay, a few occurring at about low-water mark in firm clayey sand.

\section{Nerine cirratulus (Della Chiaje)}

In I90I specimens were found on Bull Hill Bank and Cocklesand.

In 1947 it was found in small numbers on the main traverse chiefly in clean, fairly well-drained sand near Station I. It did not occur in company with Ophelia on this traverse. On Bull Hill, however, it was more abundant, occurring at all stations, and was therefore occurring with Ophelia.

The distribution of this species is discussed by Watkin (1942), who finds it to have a wide intertidal range, with maximum densities about half-tide mark. Pirrie, Bruce \& Moore (1932) describe a similar zonation on the sandy beach at Port Erin. It is recorded from muddy sand at Salcombe by Allen \& Todd (1900), and in the Mersey Estuary by Bassindale (1938).

\section{Pygospio elegans Claparède}

Allen \& Todd record this species in clean hard sand inside the estuary, but not on the Pole Sands.

Pygospio was found at nearly all stations on the main traverse, the maximum 
density being at about Station $I+67$. It was rare or absent in loose sand, and was not therefore found on Bull Hill. In small numbers it ranged on to the muddy stations of the traverse, its requirements seeming to be merely the presence of a firm substratum and of sufficient sand-grains with which to construct its tube.

In the sorting dish a number of the worms emerge from their tubes a day or two after collection, but many more probably remain within their tubes. A rough estimate of numbers was made by determining the dry weight of sandy tubes at certain stations. (Sometimes the tubes were sorted out from the general collections, at other times a special collection was made by carefully sieving the top $2-3$ in. of soil from an area close to the original station.)

There are few records of this species in Britain: if present in small numbers it might easily be overlooked. It has been found in various grades of soil near the mouth of certain estuaries. Percival (I929) records it from the River Lynher near Ince Castle, Bassindale (I938) found it in the upper estuary of the Mersey, and Allen \& Todd (I900) found it in muddy gravel under the Marine Hotel at Salcombe. Beanland (1940) records it from banks near the mouth of the Dovey Estuary, where it occurred on soils ranging from $\circ$ to $20.3 \%$ of silt-plus-clay.

\section{Ophelia bicornis Savigny}

Allen \& Todd found Ophelia to be abundant on the north-eastern side of Pole Sands and on Bull Hill. Single specimens were found at three other stations in the estuary.

In 1947 it was found in small numbers (I2 per $\mathrm{m}^{2}$ ) on clean well-drained sand at Stations I- IOO and I-40. On Bull Hill it was abundant at all stations except at low-water mark where it was absent. Its distribution was rather patchy, but a varying number could be dug up anywhere on top of the bank. The maximum density was 268 per $\mathrm{m}^{2}$

The occurrence of Ophelia is clearly related to the degree of drainage of the sand, but Wilson (I948) has shown that the grade of soil may also affect distribution. Experiments with larvae of Ophelia show that they 'metamorphose most readily in sand from their natural habitat and with hesitancy or not at all in sands from other sources'. It is shown that the size and shape of the sand grains, or perhaps of the interstices, determines the readiness with which metamorphosis occurs. Wilson has found that sand from the Salthouse Lake area is less effective in bringing about metamorphosis than the coarser sand from Bull Hill Bank. Although the Salthouse Lake sand used in the experiments was probably not from the region where Ophelia occurs, it appears to be of a similar grade to that in which small numbers of Ophelia were found.

Thus the relative numbers of Ophelia in the two localities is explicable in terms of the soil grade. 
... If this be so, we have a reasonable explanation of the observed distribution of Ophelia in the Exe estuary, a heavy concentration in the metamorphosis-stimulating sand of the Bullhill Bank and the Polesands, with a much lower concentration in the less stimulating Salthouse Lake area. As the larvae in the later pelagic stages drift over the banks the majority of these coming into contact with the Bullhill sand will enter it and stay there, but of those washed over the Salthouse Lake only a small proportion will settle, the majority will leave the sand after testing it and, continuing pelagic life, may later on eventually reach the Bullhill Bank or the almost equally suitable Polesands nearer the open sea. This explanation is at least as reasonable as supposing that there is an even settlement over the whole area followed by greater destruction of the young worms in the unfavourable soils, and the results of these experiments support it [from Wilson, 1948].

\section{Arenicola marina L.}

Allen \& Todd recorded this species as abundant on most of the banks of the estuary, being scarce on Pole Sands and on a mud-bank near the top of the estuary.

In 1947 Arenicola was found at nearly all stations in the Salthouse Lake area. It was absent from the well-drained area where Ophelia occurred, from gravel near high-water mark, and from the bed of Salthouse Lake $(\mathrm{H}+\mathrm{I} 5)$. None was found on Bull Hill.

A comparison of numbers found by digging and by counts of casts has already been described (p. 206). On the main traverse the maximum density was 52 adults per m. ${ }^{2}$, at Station III +33 , where the silt content was $6 \cdot 9 \%$. Arenicola was found in soils with $0.05-22 \cdot 6 \%$ silt.

Intertidally it ranged from the edge of the gravel, at about H.W.M.N.T. down to low-water mark. At $\mathrm{F}-3$ (half-tide mark) a density of 60 per $\mathrm{m}^{2}$ was recorded, there being only $0.6 \%$ of silt. Serventy (1934), describing the fauna of Scolt Head Island, found that Arenicola was scarce in soft muds with Zoster $a$, in hard compact mud, and in clean sand. It did, however, occasionally occur on the open beach with Ensis and Spisula. Spooner \& Moore (1940) found Arenicola to be scarce on the Tamar Estuary, where the soil contains very little sand, being almost entirely silt. Wells (1945) noticed that it was most abundant on sand where drainage was poor: where a stretch of sand dried out soon after the tide had receded, only small specimens were found.

Newell (I948) has recently investigated the life history of Arenicola. Fertilized eggs appear to be carried up the beach on the incoming tide and become lodged among pebbles or sand, where larval development probably takes place. The maximum spawning intensity at Whitstable is at neap tides (in October) so that the eggs tend to be deposited at high-neap-tide mark rather than in unfavourable environments higher up the beach. The larvae metamorphose in the following spring.

Casual observations in the Salthouse Lake area indicated that large numbers of small Arenicola did occur high up the beach (many well above high water of neap tides, however), suggesting that conditions are similar to those at 
Whitstable. On the traverses numbers of small specimens occurred among Zostera, below the pebble zone at $\mathrm{C}+\mathrm{I}$, and on clean sand near Station I. Perhaps the pebble zone and the Zostera beds are 'nursery areas' where the larvae develop, subsequently migrating to the regions where the adults occur.

\section{Ampharete grubei Malmgren}

This species was not recorded by Allen \& Todd. In Salthouse Lake it was abundant in the more muddy stations of the main traverse, reaching a maximum density of about 9200 per $\mathrm{m}^{2}$ at $\mathrm{V}-3$, where the silt content was the highest on the traverse $(22 \cdot 6 \%)$. Its distribution was patchy, as only 4000 per m. ${ }^{2}$ were found at the adjacent Station, $\mathrm{V}+3$. Ampharete was abundant over a range of soils with silt concentrations of $6 \cdot 9-22 \cdot 6 \%$. It was absent from Bull Hill.

There are few other records of this species: Serventy (1934) found a large colony in very soft mud at Scolt Head Island, while Spooner \& Moore (I940) record up to 4000 per m. ${ }^{2}$ at St John's Lake, from about mid-tide downwards. It did not penetrate far up the Tamar Estuary. Perhaps the scarcity of records of Ampharete is due to the few intertidal mud banks which are exposed to marine conditions; the species evidently having little tolerance of reduced salinity. The mud-flats at Salcombe would seem to provide a suitable habitat for this species, but none were found there by Allen \& Todd (1900), although it is possible that Ampharete was overlooked among collections of Melinna.

\section{Melinna palmata Grube}

Allen \& Todd found this species (recorded as M. adriatica von Marenzeller) in small numbers in the lower part of the estuary. In 1947 a few specimens were found on the more muddy parts of the Salthouse Lake traverse.

Like Ampharete, Melinna is absent from many muddy localities, but occurs in the Tamar and at Salcombe. Spooner \& Moore (1940) found it together with Ampharete in the Tamar, but penetrating farther up-river than the latter; it was most abundant at low water at the edge of West Muds, where the density was 189 per.$^{2}$

\section{Eurydice pulchra Leach}

\section{CRUSTACEA}

This species seems to have been overlooked by Allen \& Todd, perhaps on account of its small size.

In 1947 it was found on the main traverse in clean sand just below H.W.M.N.T., with a maximum density of $6 \mathrm{I} 2 \mathrm{per} \mathrm{m}^{2}{ }^{2}$ It was rare on the intertidal traverse. On Bull Hill it was quite plentiful, occurring at all stations, with a maximum density of $\mathrm{I} 68 \mathrm{per} \mathrm{m}^{2}$ On this bank it thus ranges from half-tide down to nearly L.W.M.S.T.

This species has been recorded from clean sand above half-tide mark by Brady (1943), Watkin (1942), Rees (1939), Pirrie et al. (1932) and by Elmhirst (I93I). Crawford (1937b), however, records it from sand about half-tide 
mark downwards. Its intertidal distribution is perhaps related to the degree of drainage of the sand.

Elmhirst (I93I) has shown that it has a pelagic phase; in winter it seeks shelter in the shallow water beyond low-water springs, and in summer it may swim in large numbers, following the flotsam at the edge of the tide. Watkin (I94I $b$ ), however, states that they 'rise out of the sand with the inflowing tide, proceed to feed immediately and sink again into the sand with the retreating tide'.

\section{Bathyporeia pilosa Lindström}

The systematics of the genus Bathyporeia were somewhat confused before the publication of a paper by Watkin (1938), and records before 1938 are consequently unreliable.

Allen \& Todd recorded B. pelagica Sp. Bate from collections with a mosquito-net trawl in the estuary, but the few available specimens are of $B$. sarsi (see notes under the latter species).

On the Salthouse Lake traverse B. pilosa occurred from Stations I- Ioo to II on clean sand. It was most abundant on the loose well-drained sand just below H.W.M.N.T., which was not covered by extreme neap tides. The maximum density was 2180 per $\mathrm{m}^{2}$ This species was absent from Bull Hill.

Beanland (1940) found it at several stations on the Dovey, the soil having a silt content of under I \% . The maximum density was 298 per sq.ft. At Kames Bay Watkin (1942) records a density of $c .17,000$ per m. ${ }^{2}$

Species of this genus have a pelagic phase. Watkin (I939) found that in Kames Bay $B$. pilos $a$ occupied a definite belt across the shore at a level above H.W.M.N.T. Tow-nettings made at high tide showed that the different species became pelagic, but each more or less retained its zonation, returning to its own area at low tide. Watkin (1938) gives a list of localities for this species.

\section{Bathyporeia sarsi Watkin}

This species is distinguished from B. pilosa by several minor characters, the most conspicuous being the shape of the basal joint of the antennule (which is relatively broader in B. sarsi) and by the number of groups of spines on the third epimeral plate. Specimens in the museum of the Plymouth Laboratory show that some of the specimens recorded by Allen \& Todd (I902) as $B$. pelagica $\mathrm{Sp}$. Bate were in fact what is now B. sarsi Watkin. The specimens in question were caught on 8 July I9or between Cockwood and Bull Hill Bank.

On the Salthouse Lake traverse it occurred in moist sand from Station $\mathrm{I}+67$ to Station III +33 , thus slightly overlapping the $B$. pilosa zone. Intertidally it extended from about high-neap-tide mark downwards. The maximum density was at $\mathrm{F}-3$ (half-tide mark) where there were 352 per m. ${ }^{2}$ On Bull Hill it occurred at all but one station, the greatest density, 96 per $\mathrm{m}^{2}$, being at low-water mark. 
A short list of localities is given by Watkin (1938); it is an intertidal or shallow water form.

\section{Haustorius arenarius (Slabber)}

Haustorius was found by Allen \& Todd in Pole Sands, Shaggles Sand, and in sand north of the Warren.

In 1947 only five specimens were found; three in wet sand below half tide on the intertidal traverse, and two on Bull Hill near low-water mark.

This seems to be nowhere an abundant species; Watkin (1942) records 2I per sq.ft. near high-neap-tide mark in Kames Bay. Its intertidal distribution, which is variable, is discussed by Watkin.

\section{Corophium arenarium Crawford}

This species was created by Crawford (1937a) to distinguish a form closely resembling C. volutator (Pallas), but which occurs in sandy habitats. It is possible, and indeed likely, that $C$. arenarium was found in the I90I survey but was included with $C$. grossipes $\mathrm{L}$. (=volutator). $C$. volutator also occurs in this area (Crawford, I937c).

On the Salthouse Lake traverses $C$. arenarium was found on a wide range of substrata, being scarce, however, on loose sand and on mud with Zostera. Its maximum abundance was at II $+67: 360$ per $\mathrm{m}^{2}{ }^{2}$, where the silt content of the soil was $2 \cdot 2 \%$. Intertidally it ranged from above H.W.M.N.T. to about half-tide mark. It was absent from Bull Hill.

Crawford (I937a) found it in firm but slightly muddy sand from half tide to L.W.M.N.T. It is recorded from the Dovey Estuary by Beanland (1940) and by Watkin (I94I $a$ ). Watkin states that 'away from the influence of the streams and above the high-water mark of neap tides Corophium volutator is replaced by $C$. arenarium, which is the dominant species in the estuary. The two species may overlap at their limits of distribution; but at their centres of density, which in all cases are well marked, they remain unmixed'.

The occurrence of the two species in the same area seems to confirm the validity of $C$. arenarium as a separate species. Furthermore, $\mathrm{Mr}$ Spooner informs me he has observed additional morphological differences between them.

\section{Tellina tenuis da Costa}

\section{MOLLUSCA}

In I90I Tellina was common on the west side of Pole Sands at low-water mark, and between Cocklesand and Lympstone mussel beds; a few were taken on Bull Hill, the Warren and Shaggles Sand.

In 1947 this species was found in moderate numbers on moist clean sand. The maximum density on the main traverse being 88 per m. ${ }^{2}$ at II +3 . Intertidally it occurred up to nearly H.W.M.N.T., and extended down to low-water mark. Population densities in the lower half of the tidal zone were remarkably constant, averaging $\mathrm{I} 84$ per $\mathrm{m}^{2}{ }^{2}$ On Bull Hill the species is restricted to a zone 
near low-tide mark, but one individual was found on top of the bank. The length of shell of each specimen was measured to the nearest mm. 'above', the results being shown in Table XIII.

Tellina has been studied by Stephen (1928, I929 $a, b$, I93I). Populations in Kames Bay reached I897 per $\frac{1}{4} \mathrm{~m}^{2}{ }^{2}$, but elsewhere lower densities, averaging 250 per $\frac{1}{4} \mathrm{~m} .{ }^{2}$, are recorded by Stephen. In Kames Bay densities decreased from low- to high-water mark; large individuals occurring mainly at the higher levels, whereas many small animals were found at low-water mark.

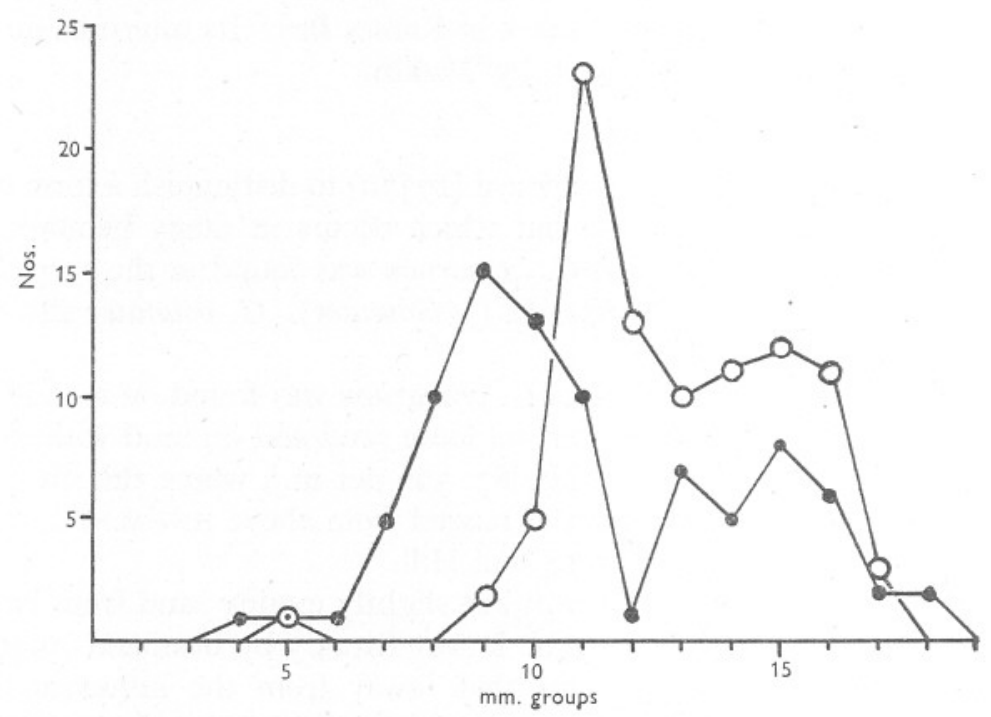

Fig. II. Length-frequency distribution graphs for Tellina tenuis at Stations F (half-tide mark) and $\mathrm{H}$ (low-tide mark); I4 and I5 August I947. Based on ninety-one individuals from $\mathrm{F}$ and eighty-seven from $\mathrm{H}$. - - O - Station $\mathrm{F} ;-1-$, Station $\mathrm{H}$.

The density of Tellina on Salthouse Lake was very much less than in areas studied by Stephen, numbers not being large enough to give statistically significant results after size-grouping. Comparison with Stephen's results, however, shows the following features:

(i) Population density decreased at higher levels on the beach; but up to about half-tide mark densities were uniform.

(ii) Measurements of shell length show that on the whole a greater proportion of the smaller size-groups occurred near low water. This is shown in Fig. II. The maxima for what may be a year group occur at $9 \mathrm{~mm}$. length at low-tide mark, but at II mm. length for individuals from half-tide mark, suggesting a greater growth rate in the latter position.

(iii) Stations at the same level on the main traverse showed little difference in the numerical proportions of the different size-groups, although the population density was variable. 
The species has been found on a number of sandy estuaries and shores where there is some shelter from wave action. Rees (1939) found that the extent of its range up the beach from low-water mark was variable. This is probably related to drainage, as Tellina is restricted to low-water mark on Bull Hill where the drainage is very thorough.

\section{Macoma balthica (L.)}

In I90I this was recorded (as Tellina balthica L.) from the mud flats between Cocklesand and Exmouth railway station, on mud, south of Lympstone mussel-bed, and on the west side of the estuary.

In the Salthouse Lake area it occurred on the main traverse on soils ranging from moist sand to mud. The maximum density was $24 \mathrm{per} \mathrm{m}^{2}$ at IV -3 , where the silt content was $16 \cdot 6 \%$. On the intertidal traverse it was restricted to a zone at about half-tide mark, but two were found in the bed of Salthouse Lake. It was absent from Bull Hill.

Comparable densities, up to $36 \mathrm{per} \mathrm{m.}{ }^{2}$, were recorded by Spooner \& Moore (1940) from St John's Lake, where it was fairly evenly distributed through the tidal zone. As on the Exe, few spat were found. Population figures for other areas, quoted by Spooner \& Moore, show that very much higher densities may occur. Beanland (1940) found populations up to 657 per sq.ft. on the Dovey, over a soil range from $0-32 \cdot 4 \%$ silt, with maximum densities where there was $2 \cdot 5-4.3 \%$ silt. Brady (1943) showed an inverse relation between densities of Macoma and of Scoloplos, which is discussed in the notes on the latter species.

\section{Scrobicularia plana (da Costa)}

This was recorded by Allen \& Todd (as S. piperata (L.)) as one of the commonest bivalves of the estuary.

On the main traverse it occurred at all stations from III to VI, on mud and muddy sand; and small individuals (under Io $\mathrm{mm}$. long) also occurred on wet sand from I to III. It reached its maximum abundance at IV +33, where there were 156 'adults' and 72 'young' per $\mathrm{m}^{2}$ Intertidally it occurred over a fairly narrow range at about half tide, and was absent from Bull Hill. Measurements of shell-length are shown in Table XIV.

Spooner \& Moore (1940) state that this species is characteristic of estuaries in the south and east of England, but is scarce and more local in the north. On the Tamar conditions for settlement of spat seemed to be most favourable at the seaward end of the estuary, while growth conditions were at an optimum much higher up the estuary. The great majority of spat settling on St John's Lake, near the mouth of the estuary, die off at an early age. 
Cardium edule L.

Cockles are plentiful in the estuary: Allen \& Todd recorded them in profusion from Cocklesand, Bull Hill Bank, and along the west side of the estuary.

In the Salthouse Lake area Cardium occurred on a wide range of soils, from clean sand to mud, and from high-water mark of neap tides down to the bed of Salthouse Lake. It was absent from well-drained sand at one end of the main traverse, and from Bull Hill Bank (the cockle bed is farther to the north, on the gravelly part of this bank).

Its maximum abundance was in mud at Station VI-3, where there were I36 small and 60 adults per m. ${ }^{2}$ The length of the shells of individuals at each station is given in Table XVI.

A limited amount of cockle gathering occurs in the Salthouse Lake area.

\section{Hydrobia ulvae (Pennant)}

In I90I this was recorded from nearly all grounds in the estuary.

Its distribution on the main traverse is clearly related to the presence of Zostera, which provides shelter and may be a source of food. Its maximum abundance was I6,000 per m. ${ }^{2}$. Outside the Zostera beds it was much less abundant, and it was absent from areas scoured by currents, such as the bed of Salthouse Lake and the top of Bull Hill. Intertidally, it was mainly concentrated towards H.W.M.N.T. Hydrobia has the habit of floating upside down from the surface film, and may in this way be dispersed away from the Zostera beds to the sandy areas, which are not its normal habitat.

The distribution of this common estuarine species is discussed at length by Spooner \& Moore (1940).

\section{Discussion}

A study of the fauna of the main traverse on Salthouse Lake has shown that the distribution of burrowing species is closely linked with the nature of the soil. Drainage may be of importance at one end of the traverse, but most of the stations had standing water on the surface at low tide.

Although conclusions as to the role of the soil as a limiting factor can only be applied with confidence to the area investigated, they should also apply (modified by divergencies in other factors) to the fauna of other areas. The great value of the Salthouse Lake traverse lay in the opportunity it offered for a study of the influence of soil grade on distribution, the effect of other factors being eliminated owing to the peculiar local conditions.

A striking example of the influence of silt on distribution is exhibited by the difference in the fauna on either side of Station III. On one side was an area with a silt content of under $2.5 \%$, and on the other side there was over $6.5 \%$ silt. This difference is clearly shown in the distribution of certain species. Thus Bathyporeia sarsi, Urothöe grimaldii and Tellina tenuis were restricted to the former area, whereas Ampharete grubei and Melinna palmata 
occurred only in the latter area. Some species, more tolerant of variable silt concentrations, ranged across the two areas, but these often showed a marked change in density.

The apparent correlation between distribution of animals and silt content, however, can establish neither the degree to which silt can be regarded as a limiting factor, nor its method of operation. The observed distribution of species may be related to: (i) a direct effect of silt on distribution; (ii) an indirect effect of silt, through its effects on the type of vegetation, consistency of the soil, drainage, or some chemical or physical factor in the soil; (iii) some other factor of which silt may merely be an indicator. With regard to the last, the organic content of a soil is probably closely related to the quantity of silt, since both fine organic matter and silt tend to settle in the more sheltered parts of an estuary. In grade analysis much of this organic matter will be represented in the silt fraction, though it would appear that in the samples dealt with here much of the silt was of inorganic origin.

It would seem possible that silt as such limits the inhabitants of clean sand to their normal habitat, whereas the mud-living species are restricted to the muddy areas on account of the abundant food supply in the form of detritus.

As yet very little is known of the action of the factors limiting the distribution of intertidal animals, but they presumably operate in one of three ways: by their influence on the settling reactions of planktonic larvae, by their effect on the migration of adults, or by affecting mortality after metamorphosis. Ophelia has already been cited as an example of a species whose distribution and density is partly determined by the settling reactions of the larvae. Lamellibranchs probably move about to a considerable extent after metamorphosis, and their distribution may be related to a choice of the more favourable grounds during the course of their wanderings.

Chapman \& Newell (I947) have emphasized the possible importance of the 'thixotropic' properties of a soil in relation to the burrowing of Arenicola. The ease with which a burrower can penetrate the soil is enhanced by the capacity of thixotropic soils to decrease their resistance to penetration immediately after agitation. The thixotropic properties of a soil depend upon a high water content and also upon the presence of small quantities of colloidal substances. At Whitstable, as on Salthouse Lake, a layer of clay occurs beneath the surface, and this is believed to supply these colloidal substances to the soil. Thus the presence of small quantities of silt or clay may profoundly alter the properties of a sand and hence its suitability for burrowing species.

At one end of the main traverse there is a marked change in the fauna of the clean sand, which is almost certainly due to the better drainage conditions in this area. Most of the species common on the rest of the traverse are absent, but Ophelia occurs here and nowhere else on Salthouse Lake. Thus the distribution of Ophelia and intertidal species such as Tellina would appear 
to be complementary, the one depending on a well-drained, the other on a water-saturated soil. This is emphasized by the distribution of these species in the extremely well-drained sand on Bull Hill Bank. Here Ophelia extends almost to low-water mark, but wherever the soil is wet, Ophelia is absent and Tellina appears.

The intertidal distribution of many species cannot, however, be explained in terms of drainage conditions. Thus Bathyporeia pilosa occurs only in a zone at high-neap-tide mark, although Eurydice, which exhibits a similar zonation on Salthouse Lake, ranges down to low-water mark on Bull Hill.

\section{SUMMARY}

Erosion of Dawlish Warren, at the mouth of the Exe Estuary has resulted in a redistribution of sand, which has come to lie in close proximity to certain of the original mud banks.

Quantitative collections of the macrofauna were made along a traverse passing from the newly deposited sand to the old mud bank, stations all being at about half-tide level.

Measurements of salinity, temperature, $\mathrm{pH}$, currents and wave action show that these are similar for all stations. Thus it has been possible to observe the distribution of the fauna in relation to the type of soil without the usual complications due to differences in other factors.

The occurrence and density of many species is shown to be correlated with the silt content of the soil, or some factor related to it. A traverse extending from high- to low-tide marks was worked in the same area. This provides information on the intertidal distribution of species occurring in the main traverse.

An additional traverse was worked on Bull Hill Bank, a sand bank which is much scoured by currents. The distribution of the fauna on this bank emphasizes the importance of soil drainage on distribution.

The distribution of certain species is discussed in the light of data obtained from other areas. No marked changes in the fauna of the estuary seem to have occurred since a survey of the estuary was made by Allen \& Todd in I90I.

The possible mode of action of limiting factors is briefly discussed.

\section{REFERENCES}

Alexander, W. B., Southgate, B. A. \& Bassindale, R., I935. Survey of the River Tees. Part II. The Estuary-chemical and biological. D.S.I.R. Water Pollution Research, Tech. Paper No. 5. H.M. Stationery Office.

Allen, E. J. \& Todd, R. A., I900. The fauna of the Salcombe Estuary. Fourn. Mar. Biol. Assoc., Vol. vi, pp. 15I-2I7.

- I902. The Fauna of the Exe Estuary. Fourn. Mar. Biol. Assoc., Vol. vI, pp. 295-335.

Bassindale, R., I938. The Intertidal fauna of the Mersey Estuary. Fourn. Mar. Biol. Assoc., Vol. xxIII, pp. 83-98. 
Beanland, F. L., I940. Sand and mud communities in the Dovey Estuary. Fourn. Mar. Biol. Assoc., Vol. xxiv, pp. 589-6II.

Brady, F., I943. The distribution of the fauna of some intertidal sands and muds on the Northumberland Coast. F. Anim. Ecol., Vol. I2, pp. 27-4I.

BRUCE, J. R., I928. Physical factors on the sandy beach. Part II. Chemical changescarbon dioxide concentration and sulphides. Fourn. Mar. Biol. Assoc., Vol. xv, pp. 553-65.

Chapman, G. \& Newell, G. E., 1947. The role of the body fluid in relation to movement in soft-bodied invertebrates. I. The burrowing of Arenicola. Proc. Roy. Soc. B., Vol. I34, pp. 43I-55.

Chevreux, E. \& FAGE, L., I925. Amphipodes. Faune de France, Vol. Ix. 488 pp. Paris.

CRAWFoRD, G. I., I937a. A review of the Amphipod genus Corophium, with notes on the British species. Fourn. Mar. Biol. Assoc., Vol. xxI, pp. 589-630.

$1937 b$. Notes on the distribution of burrowing Isopoda and Amphipoda in various soils on the sea-bottom near Plymouth. Fourn. Mar. Biol. Assoc., Vol. XxI, pp. $63 \mathrm{I}-46$.

- I937c. The Fauna of certain estuaries in West England and South Wales, with special reference to the Tanaidacea, Isopoda and Amphipoda. Fourn. Mar. Biol. Assoc., Vol. xxI, pp. 647-62.

DAY, J. H. \& WILSON, D. P., I934. On the relationship of the substratum to the metamorphosis of Scolecolepis fuliginosa (Claparède). Fourn. Mar. Biol. Assoc., Vol. xIx, pp. 655-62.

Elmhirst, R., I93I. Studies in the Scottish Marine Fauna. The Crustacea of the Sandy and Muddy Areas of the Tidal Zone. Proc. Roy. Soc. Edin., Vol. LI, pp. I69-75.

Fauvel, P., I923. Polychètes errantes. Faune de France, Vol. v, 488 pp. Paris.

- 1927. Polychètes sédentaires. Faune de France, Vol. xvi. 494 pp. Paris.

Fischer-PietTe, E., I93I. Sur la pénétration des diverses espèces marines sessiles dans les estuaires et sa limitation par l'eau douce. Ann. Inst. Oceanogr., Tome X, fasc. 8 , pp. 217-43.

MacGinitie, G. E., I935. Ecological aspects of a California marine estuary. Amer. Midl. Nat., Vol. I6, pp. 629-765.

Malmgren, A. J., I865. Nordiska Hafs-Annulater. K. Vet. Akad. Forhandlingar, I865, No. I, pp. 5 I-IIo.

Marine Biological Association, I93I. Plymouth Marine Fauna. (2nd ed.)

MILNE, A., I940. Some ecological aspects of the intertidal area of the Aberdeenshire Dee. Trans. Roy. Soc. Edin., Vol. Lx, pp. 107-40.

Newell, G. E., I948. A contribution to our knowledge of the life history of Arenicola marina L. Fourn. Mar. Biol. Assoc., Vol. xxviI, pp. 554-80.

Newton, L., I931. A handbook of the British Seaweeds. 478 pp. British Museum, London.

ÖRSTED, A. S., I843. Annulatorum Danicorum Conspectus. Fasc. I. Maricolae. pp. I-32.

Percival, E., I929. A report on the fauna of the estuaries of the River Tamar and the River Lynher. Fourn. Mar. Biol. Assoc., Vol. xvI, pp. 8I-108.

PIPER, C. S., I942. Soil and plant analysis. A Monograph from the Waite Agricultural Research Institute, $368 \mathrm{pp}$. Adelaide: University of Adelaide.

Pirrie, M. E., Bruce, J. R. \& Moore, H. B., I932. A quantitative study of the fauna of the sandy beach at Port Erin. Fourn. Mar. Biol. Assoc., Vol. xvIII; pp. 279-96.

REES, C. B., I939. Notes on the ecology of the sandy beaches of North Donegal. Proc. Roy. Irish Acad., Vol. xLv, pp. 215-29. 
ReID, D. M., 1930. Salinity interchange between sea water in sand and overflowing fresh water at low tide. Fourn. Mar. Biol. Assoc., Vol. xvi, pp. 609-I4.

Serventy, D. L., 1934. The Marine Invertebrate Fauna. In 'Scolt Head Island', edited by J. A. Steers, Cambridge, 1934, pp. 196-213.

Spooner, G. M. \& Moore, H. B., 1940. The ecology of the Tamar Estuary. VI. An account of the macrofauna of the intertidal muds. Fourn. Mar. Biol. Assoc., Vol. xxiv, pp. 283-330.

Stephen, A. C., 1928. Notes on the biology of Tellina tenuis da Costa. Fourn. Mar. Biol. Assoc., Vol. xv, pp. 683-702.

- I929 $a$. Studies on the Scottish marine fauna: the fauna of the sandy and muddy areas of the tidal zone. Trans. Roy. Soc. Edin., Vol. LVI, pp. 29I-306.

- $1929 \mathrm{~b}$. Notes on the rate of growth of Tellina tenuis da Costa in the Firth of Clyde. Fourn. Mar. Biol. Assoc., Vol. xvi, pp. II7-29.

- - I93I. Notes on the biology of certain lamellibranchs on the Scottish Coast. fourn. Mar. Biol. Assoc., Vol. xviI, pp. 277-300.

- 1932. Notes on the biology of some lamellibranchs in the Clyde Area. Fourn. Mar. Biol. Assoc., Vol. xviII, pp. 5I-68.

Tutin, T. G., I936. New species of Zostera from Britain. Fourn. Botany, Vol. Lxxiv, pp. 227-30.

WATKIN, E. E., I938. A revision of the Amphipod genus Bathyporeia Lindström. Fourn. Mar. Biol. Assoc., Vol. xxiII, pp. 2 I I-36.

- I939. The pelagic phase in the life-history of the amphipod genus Bathyporeia. fourn. Mar. Biol. Assoc., Vol. xxiII, pp. 467-8r.

- I94I $a$. The yearly life-cycle of the amphipod, Corophium volutator. fourn. Anim. Ecol., Vol. I0, pp. 79-93.

- I94I b. Observations on the night tidal migrant Crustacea of Kames Bay. Fourn. Mar. Biol. Assoc., Vol. xxv, pp. 8I-96.

- I 942 . The macrofauna of the intertidal sand of Kames Bay, Millport, Buteshire. Trans. Roy. Soc. Edin., Vol. Lx, pp. 543-6r.

Wells, G. P., I945. The mode of life of Arenicola marina L. Fourn. Mar. Biol. Assoc., Vol. Xxvi, pp. I70-207.

WILsON, D. P., I937. The influence of the substratum on the metamorphosis of Notomastus larvae. Fourn. Mar. Biol. Assoc., Vol. xxII, pp. 227-43.

- 1948. The relation of the substratum to the metamorphosis of Ophelia larvae. Fourn. Mar. Biol. Assoc., Vol. xxvII, pp. 723-60.

Worth, R. H., I902. The Foraminifera of the Exe Estuary. Fourn. Mar. Biol. Assoc., Vol. vI, pp. 336-43.

\section{EXPLANATION OF PLATES}

\section{Plate I}

(By kind permission of the Under Secretary of State for Air)

Aerial photograph of the lower part of the Exe Estuary, taken at low tide, 3 August 1945. Submerged parts of some of the sand-banks are visible under water. Langstone Point: bottom left; Exmouth: centre right. Bull Hill is slightly to the left of the centre, and Dawlish Warren is below it. The remains of Warren Point are seen separated by a narrow channel from the rest of the spit.

\section{Plate II}

(By kind permission of the Under Secretary of State for Air)

Aerial photograph of Dawlish Warren, 13 April 1946. Warren Point has been almost completely washed away. Note the sand distributed in a north-westerly direction from the breach. Photograph taken with water at about high-neap-tide mark. Bull Hill Bank is seen top-centre; note the ridges on its surface. 


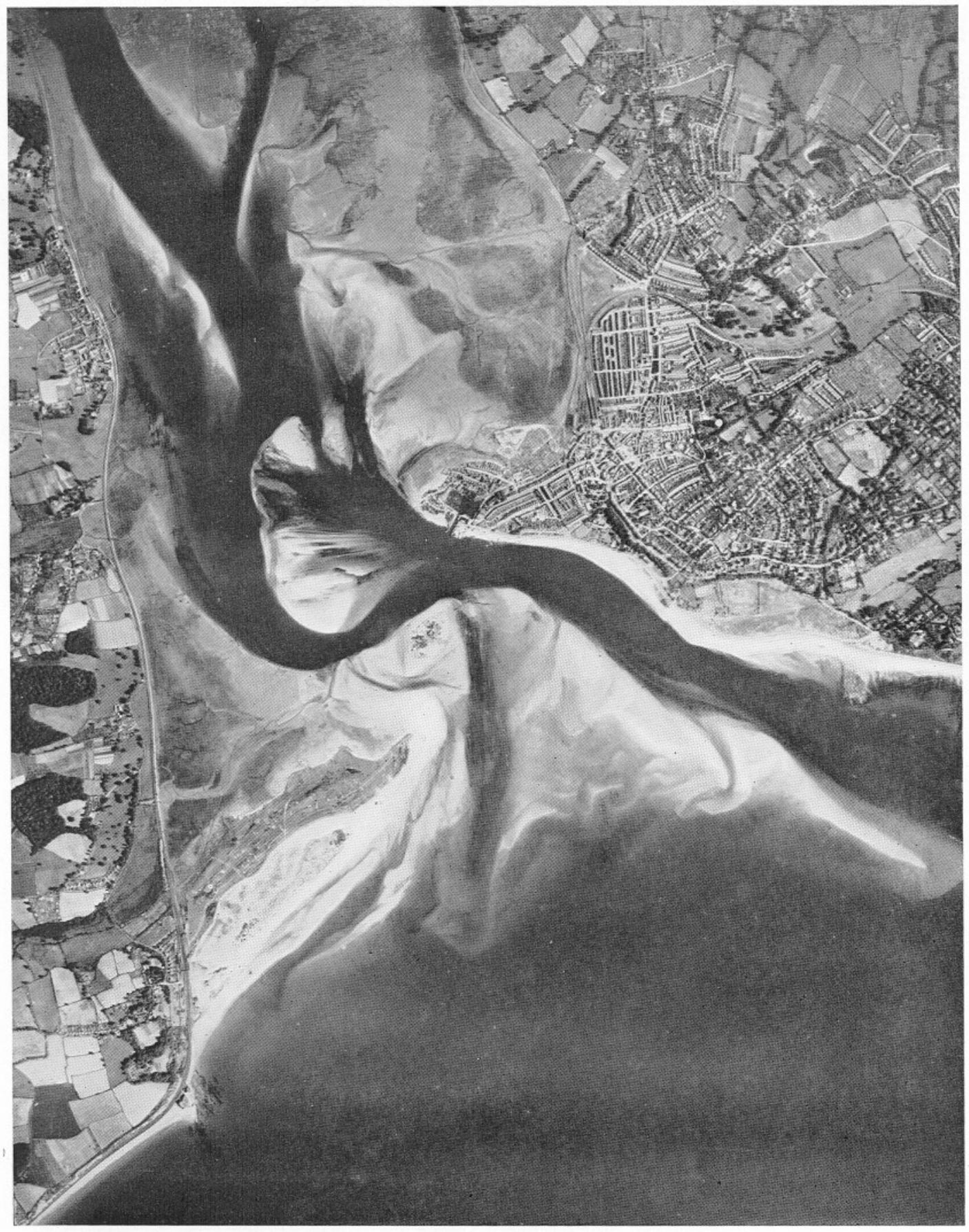




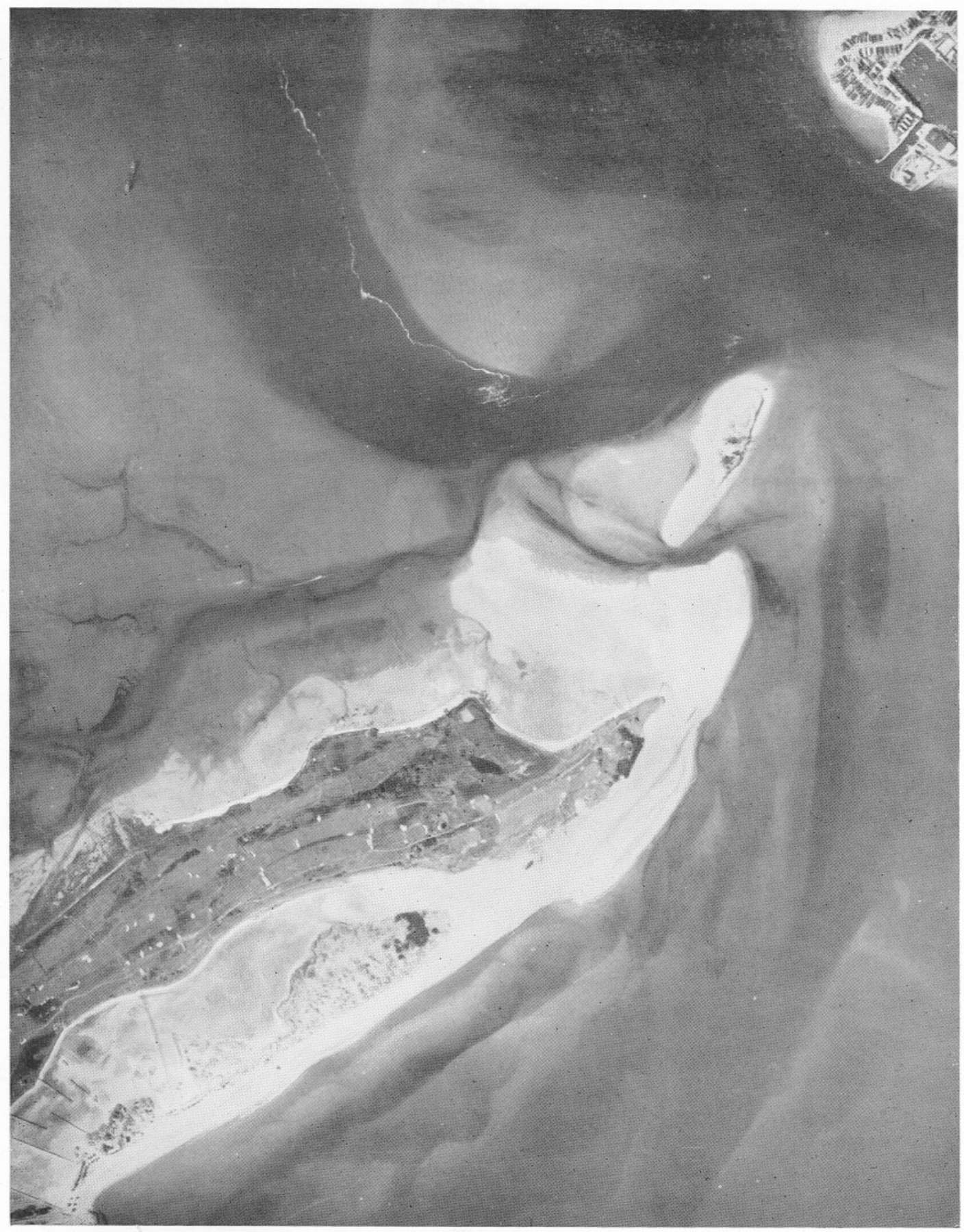




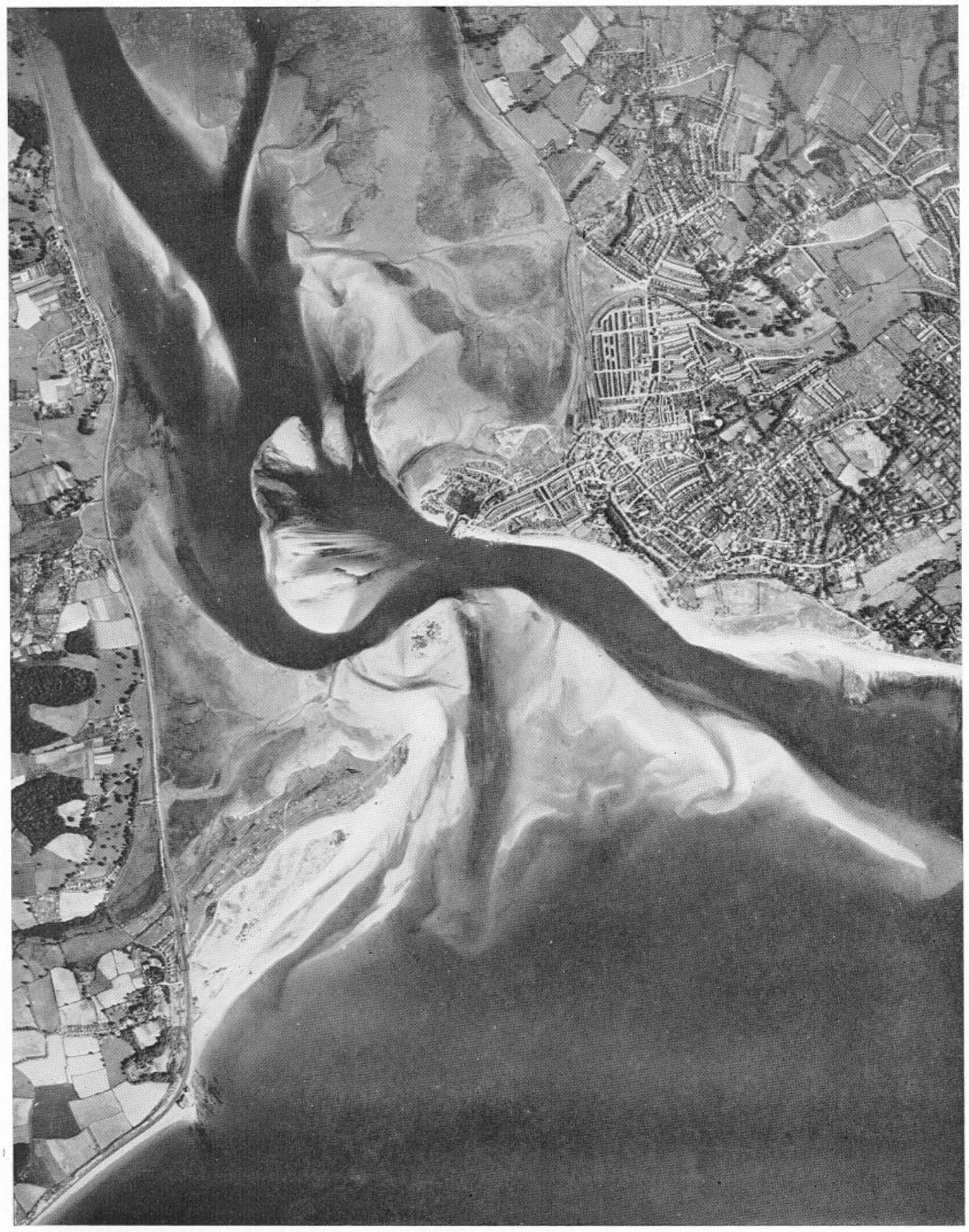




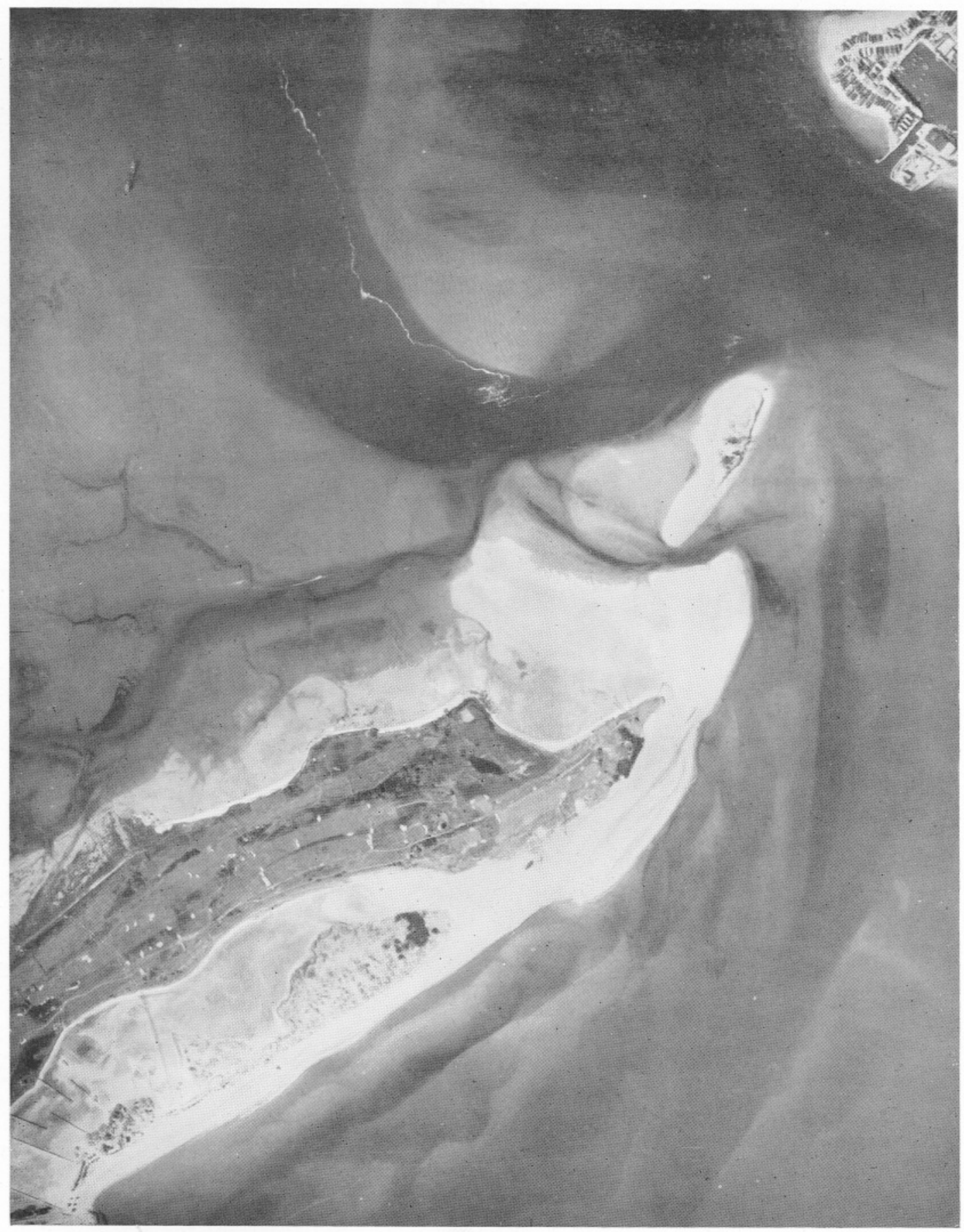




\section{APPENDIX}

\section{Table IX. Surface Salinities (Per Mille) in the Exe Estuary (SEE ALSO FIG. I)}

The stations 'A' to ' $\mathrm{I}$ ' are those indicated on the top of Fig. I. The column marked 'position' gives the distance of each station from Exmouth Pier, in miles. The readings taken in 1947 were taken during a period of drought when the River Exe was very low: those taken in the spring of I 948 when the river was at about normal level. The time each reading was taken, relative to the time of high or low tide, is indicated in italics under the salinity readings. Thus -15 is $15 \mathrm{~min}$. before, and +45 is $45 \mathrm{~min}$. after high or low water. The time and height of high tide are also given. (The readings made on 5 July 1947 are not given in Fig. I.)

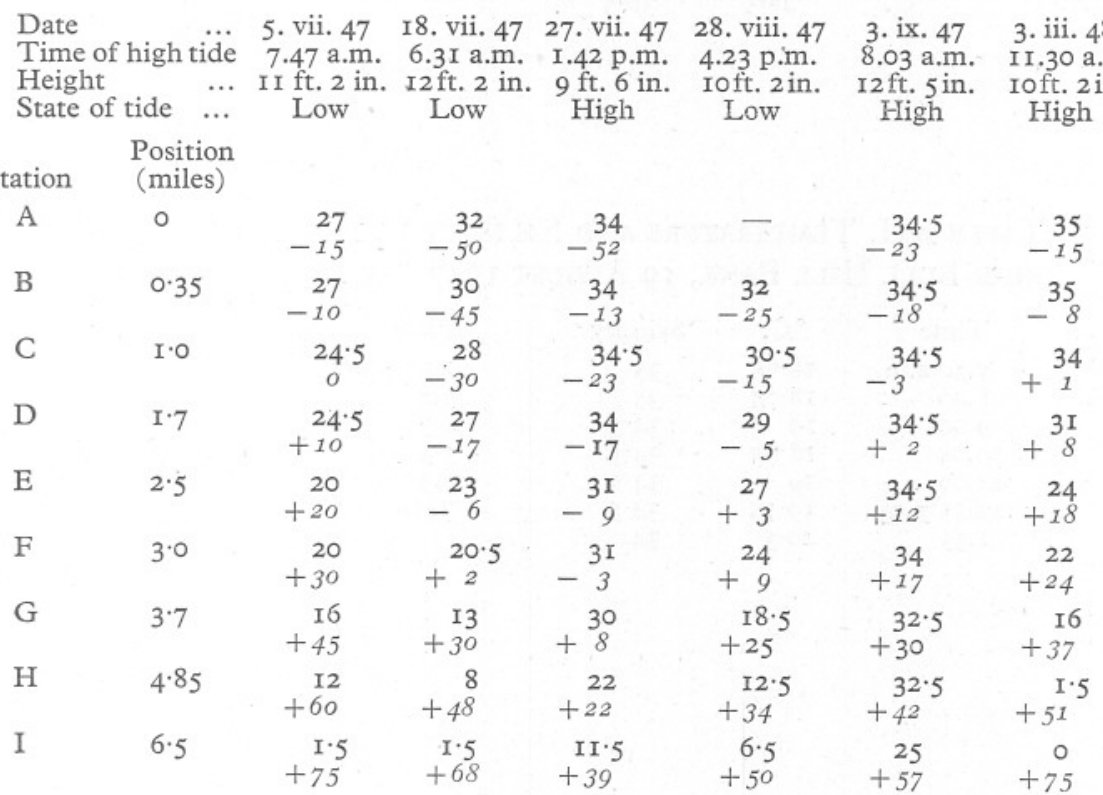

Table X. Comparison of Soll Analyses as Made here with Results Obtained, Using a 70 I.M.M. Sieve (0.2 MM. Mesh)

Samples from Station II. Percentages by weight.

$\begin{array}{cccc}\text { Grade }(\mathrm{mm} .) & \text { Percentage } & \text { Grade }(\mathrm{mm} .) & \text { Percentage } \\ \text { Over } 2 & - & \text { Over } 2 & - \\ 2-0.5 & \mathrm{I} \cdot \mathrm{I} & 2-0.5 & \mathrm{I} \cdot \mathrm{I} \\ 0.5-0.256 & \mathrm{I} \cdot 9 & 0.5-0.2 & 53 \cdot 6 \\ 0.256-0.22 & 2 \mathrm{I} \cdot 2 & - & - \\ 0.22-0.02 & 62.2 & 0.2-0.02 & 44 \cdot 2 \\ <0.02 & \mathrm{I} \cdot 6 & <0.02 & \mathrm{I} \cdot 2\end{array}$


Table XI. Temperature and Salinity Readings at Station III, I9 August 1947 (SEE ALSO Figs. 4 AND 5)

C., station covered-sample from overlying water; U., station uncovered-sample from small pool.

\begin{tabular}{|c|c|c|c|c|c|c|c|}
\hline Time & State & ${ }^{\circ} \mathrm{C}$. & Salinity & Time & State & ${ }^{\circ} \mathrm{C}$. & Salinity \\
\hline $\begin{array}{l}7.40 \text { a.m. } \\
8.05\end{array}$ & C. & 19 & $34 \cdot 5$ & 2.20 p.m. & U. & 27.25 & 36 \\
\hline $\begin{array}{l}8.05 \\
9.05\end{array}$ & C. & I9 & $35 \cdot 0$ & 3.30 & U. & 27.25 & 37 \\
\hline 9.05 & C. & I9 & $35 \cdot 5$ & 4.25 & U. & 26 & 38 \\
\hline IO.IO & C. & 19.5 & $34 \cdot 5$ & 5.25 & U. & 24 & $36 \cdot 5$ \\
\hline II.IO & C. & $2 \mathrm{I}$ & $34 \cdot 5$ & 6.10 & C. & $2 \mathrm{I}$ & 35 \\
\hline 12.45 p.m. & U. & $25 \cdot 5$ & $36 \cdot 5$ & 6.55 & C. & $20 \cdot 5$ & 36 \\
\hline I.IO & U. & $26 \cdot 5$ & $36 \cdot 5$ & & & & \\
\hline
\end{tabular}

Table XiI. Temperature and Salinity in the Main Channel, NeAr Bull Hill Bank, I9 August I947 (SEe also Figs. 4 AND 5)

$\begin{array}{llllll}\text { Time } & { }^{\circ} \mathrm{C} . & \text { Salinity } & \text { Time } & { }^{\circ} \mathrm{C} . & \text { Salinity } \\ 7.30 \text { a.m. } & \text { I8.75 } & 35 & 2.30 \mathrm{p} . \mathrm{m} . & 22 \cdot 5 & 32 \cdot 5 \\ 8.00 & \text { I8.75 } & 35 & 3.45 & 2 \mathrm{I} \cdot 5 & 32 \cdot 5 \\ 9.00 & \text { I9 } & 34 \cdot 5 & 4.35 & 2 \mathrm{I} & 33 \\ \text { I0.05 } & \text { I8.75 } & 34 \cdot 5 & 5 \cdot 35 & 20 \cdot 5 & 34 \cdot 5 \\ \text { II.00 } & \text { I9 } & 34 \cdot 5 & 6.35 & 20 & 34 \cdot 5 \\ \text { I2.35 p.m. } & \text { I9.75 } & 34 \cdot 5 & 7.00 & 20 & 34 \cdot 5 \\ \text { I.35 } & 20.5 & 34 & & & \end{array}$


Table XIII. 'Biomass' of the Fauna, in G. Per M. ${ }^{2}$ Determined From Weights of Preserved SPecimens

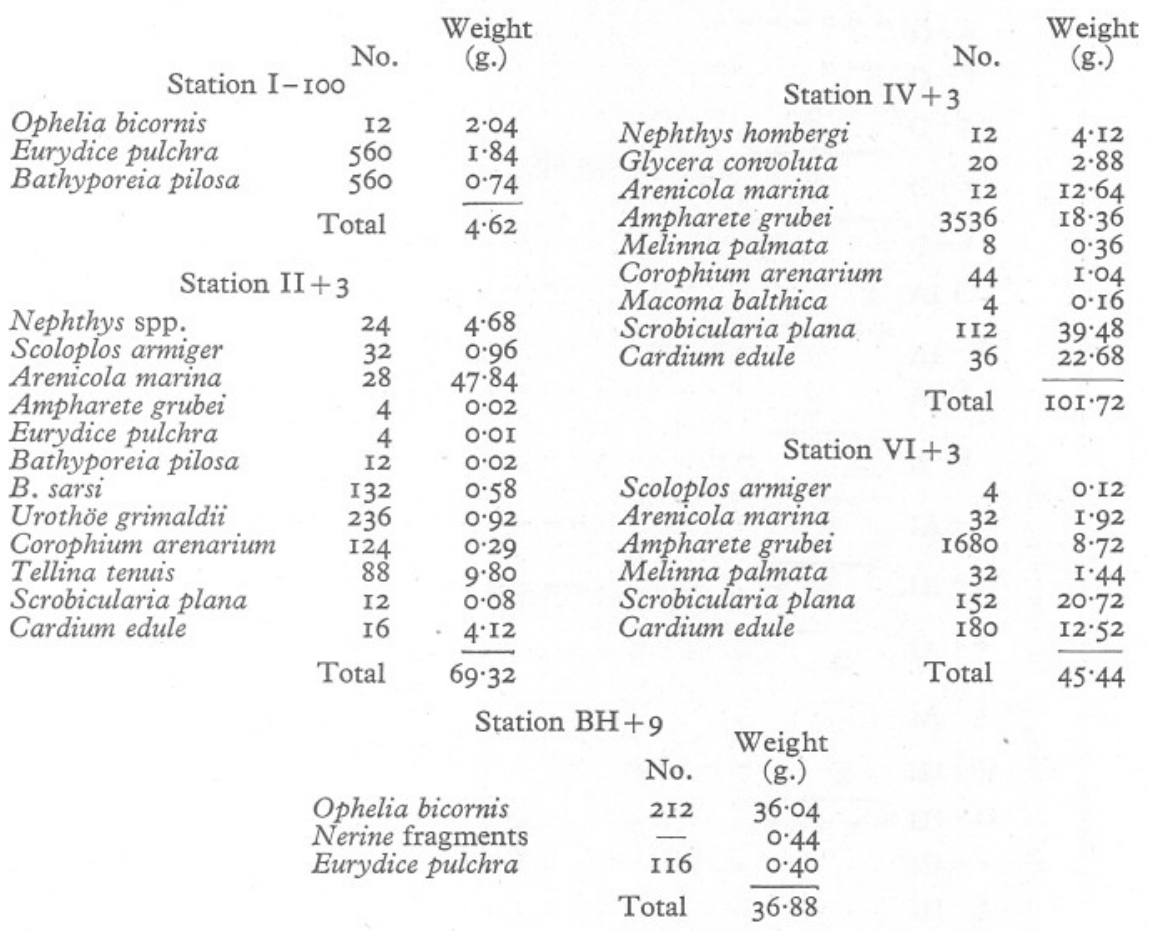

\section{Table XIV. TELLINA TENUIS. Numbers of Individuals IN EACH MM. LENGTH GROUP}

Length of shell taken to nearest mm. 'above'.

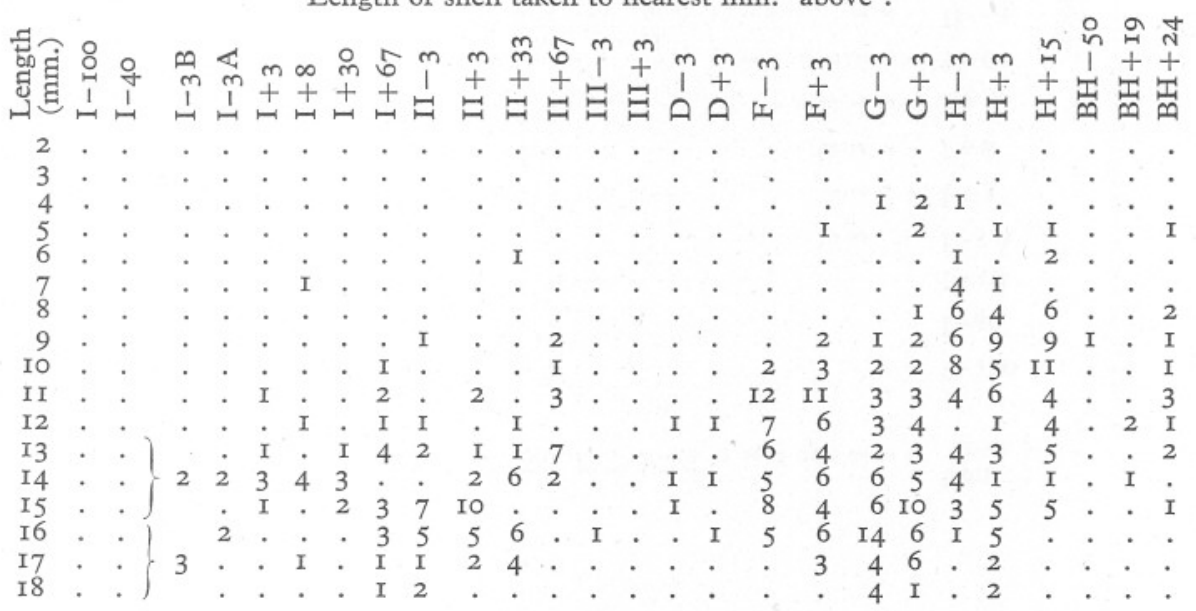


Table XV. Scrobicularia plana. Number of Individuals in Each mm. Length Group

Figures in italics unreliable owing to subsampling error.

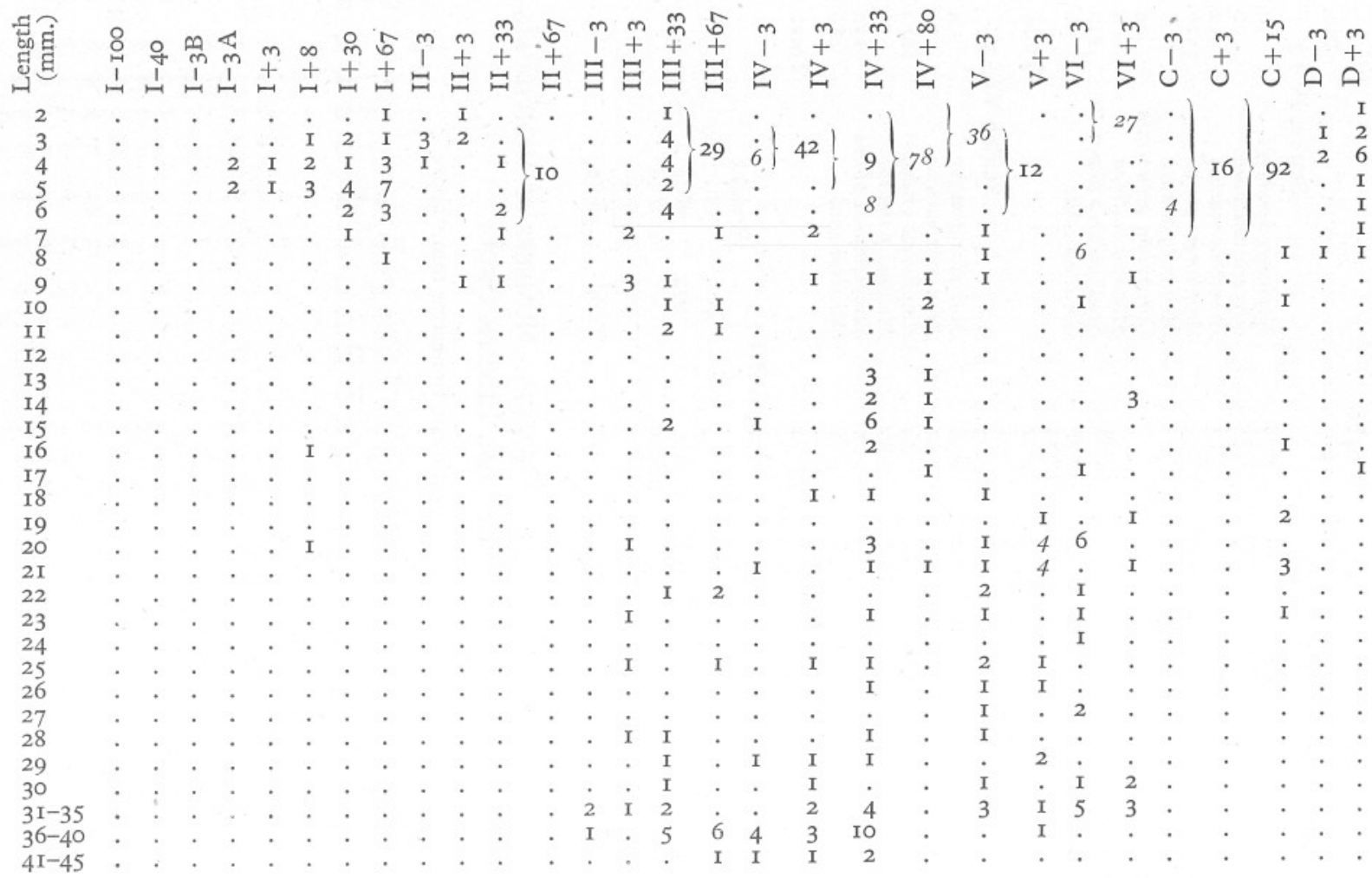


Table XVI. Cardium edule. Number of Individuals in Each mm. Length Group

Figures in italics unreliable owing to subsampling error.

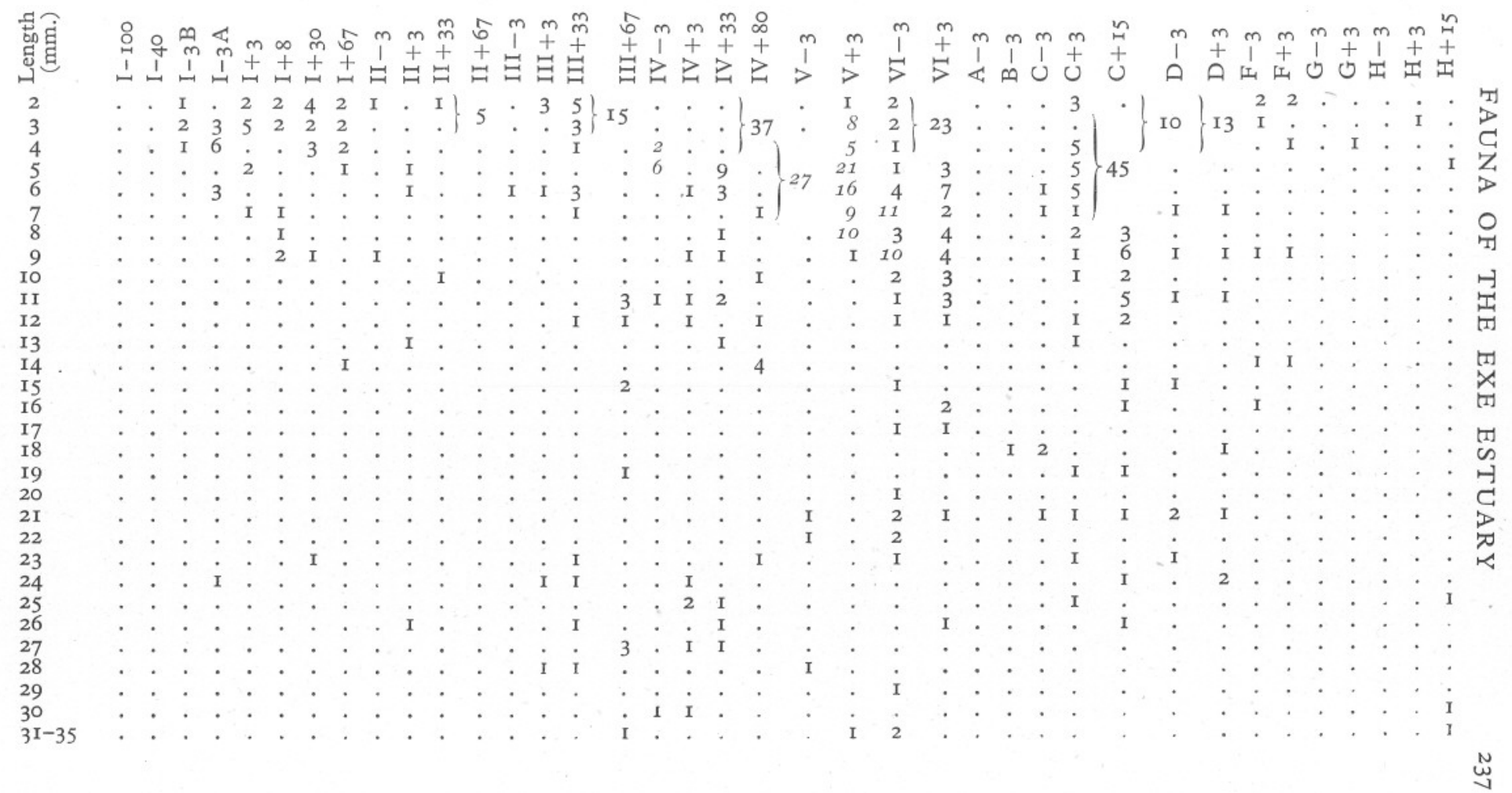

